\title{
AGES AND GEOLOGIC HISTORIES OF MARTIAN METEORITES
}

\author{
L.E. NYQUIST ${ }^{1}$, D.D. BOGARD ${ }^{1}$, C.-Y. SHIH ${ }^{2}$, A. GRESHAKE ${ }^{3}$, D. STÖFFLER ${ }^{3}$ \\ and O. EUGSTER ${ }^{4}$ \\ ${ }^{1}$ SN/Planetary Sciences, NASA Johnson Space Center, 2101 NASA Road 1, \\ Houston, TX 77058-3696, USA \\ ${ }^{2}$ Basic and Applied Research Department, Lockheed-Martin Space Operations, 2400 NASA Road 1, \\ Houston, TX 77058-3696, USA \\ ${ }^{3}$ Institut für Mineralogie, Museum für Naturkunde, Invalidenstr. 43, D-10115 Berlin, Germany \\ ${ }^{4}$ Physikalisches Institut, University of Bern, Sidlerstr. 5, CH-3012 Bern, Switzerland
}

Submitted: 28 July 2000; accepted: 16 February 2001

\begin{abstract}
We review the radiometric ages of the 16 currently known Martian meteorites, classified as 11 shergottites ( 8 basaltic and 3 lherzolitic), 3 nakhlites (clinopyroxenites), Chassigny (a dunite), and the orthopyroxenite ALH84001. The basaltic shergottites represent surface lava flows, the others magmas that solidified at depth. Shock effects correlate with these compositional types, and, in each case, they can be attributed to a single shock event, most likely the meteorite's ejection from Mars. Peak pressures in the range 15 - $45 \mathrm{GPa}$ appear to be a "launch window": shergottites experienced $\sim 30-45 \mathrm{GPa}$, nakhlites $\sim 20 \pm 5 \mathrm{GPa}$, Chassigny $\sim 35 \mathrm{GPa}$, and ALH84001 35 - $40 \mathrm{GPa}$. Two meteorites, lherzolitic shergottite Y-793605 and orthopyroxenite ALH84001, are monomict breccias, indicating a two-phase shock history in toto: monomict brecciation at depth in a first impact and later shock metamorphism in a second impact, probably the ejection event.

Crystallization ages of shergottites show only two pronounced groups designated $\mathrm{S}_{1}(\sim 175 \mathrm{Myr})$, including 4 of 6 dated basalts and all 3 lherzolites, and $S_{2}(330-475 \mathrm{Myr})$, including two basaltic shergottites and probably a third according to preliminary data. Ejection ages of shergottites, defined as the sum of their cosmic ray exposure ages and their terrestrial residence ages, range from the oldest ( $\sim 20 \mathrm{Myr}$ ) to the youngest $(\sim 0.7 \mathrm{Myr}$ ) values for Martian meteorites. Five groups are distinguished and designated $\mathrm{S}_{\mathrm{Dho}}$ (one basalt, $\sim 20 \mathrm{Myr}$ ), $\mathrm{S}_{\mathrm{L}}$ (two lherzolites of overlapping ejection ages, $3.94 \pm$ $0.40 \mathrm{Myr}$ and $4.70 \pm 0.50 \mathrm{Myr}$ ), $\mathrm{S}$ (four basalts and one lherzolite, $\sim 2.7-3.1 \mathrm{Myr}$ ), $\mathrm{S}_{\mathrm{DaG}}$ (two basalts, $\sim 1.25 \mathrm{Myr}$ ), and $\mathrm{S}_{\mathrm{E}}$ (the youngest basalt, $0.73 \pm 0.15 \mathrm{Myr}$ ). Consequently, crystallization age group $S_{1}$ includes ejection age groups $S_{L}, S_{E}$ and 4 of the 5 members of $S$, whereas $S_{2}$ includes the remaining member of $S$ and one of the two members of $S_{\mathrm{DaG}}$. Shock effects are different for basalts and lherzolites in group $S / S_{1}$. Similarities to the dated meteorite DaG476 suggest that the two shergottites that are not dated yet belong to group $S_{2}$. Whether or not $S_{2}$ is a single group is unclear at present. If crystallization age group $S_{1}$ represents a single ejection event, pre-exposure on the Martian surface is required to account for ejection ages of $S_{L}$ that are greater than ejection ages of $\mathrm{S}$, whereas secondary breakup in space is required to account for ejection ages of $\mathrm{S}_{\mathrm{E}}$ less than those of $\mathrm{S}$. Because one member of crystallization age group $\mathrm{S}_{2}$ belongs to ejection group $\mathrm{S}$, the maximum number of shergottite ejection events is 6 , whereas the minimum number is 2 .

Crystallization ages of nakhlites and Chassigny are concordant at $\sim 1.3$ Gyr. These meteorites also have concordant ejection ages, i.e., they were ejected together in a single event (NC). Shock effects vary within group NC between the nakhlites and Chassigny.

The orthopyroxenite ALH84001 is characterized by the oldest crystallization age of $\sim 4.5 \mathrm{Gyr}$ Its secondary carbonates are $\sim 3.9 \mathrm{Gyr}$ old, an age corresponding to the time of Ar-outgassing from silicates. Carbonate formation appears to have coincided with impact metamorphism, either directly, or indirectly, perhaps via precipitation from a transient impact crater lake.
\end{abstract}


The crystallization age and the ejection age of ALH84001, the second oldest ejection age at $15.0 \pm 0.8 \mathrm{Myr}$, give evidence for another ejection event $(\mathrm{O})$. Consequently, the total number of ejection events for the 16 Martian meteorites lies in the range $4-8$.

The Martian meteorites indicate that Martian magmatism has been active over most of Martian geologic history, in agreement with the inferred very young ages of flood basalt flows observed in Elysium and Amazonis Planitia with the Mars Orbital Camera (MOC) on the Mars Global Surveyor (MGS). The provenance of the youngest meteorites must be found among the youngest volcanic surfaces on Mars, i.e., in the Tharsis, Amazonis, and Elysium regions.

Keywords: shock effects, crystallization ages, cosmic ray exposure ages, ejection ages, provenance

\section{Introduction}

The clan of Martian meteorites, formerly called SNCs after Shergotty, Nakhla and Chassigny, now consists of 16 unpaired meteorites of magmatic origin (basalts and ultramafic cumulates). Generally young crystallization ages (with the exception of one pyroxenite), characteristic isotopic compositions of $\mathrm{C}, \mathrm{N}, \mathrm{O}$, and noble gases, as well as distinct major and trace element concentrations, distinguish them from all other differentiated meteorites (McSween, 1994; Clayton and Mayeda, 1996; Dreibus and Wänke, 1987; Wänke and Dreibus, 1988; Wänke, 1991). The most convincing evidence for the Martian origin of these rocks is given by isotopic measurements of trapped gases in shock-melted glass of shergottites. It was found that the isotopic composition of these gases is indistinguishable from Martian atmosphere within the measurement errors of the mass spectrometer on board the Viking lander (e.g., Bogard and Johnson, 1983; Becker and Pepin, 1984; Swindle et al., 1986; Marti et al., 1995).

Those who have followed the development of the hypothesis of the Martian origin of these meteorites will recognize that much of the early information about them was obtained in attempts to verify that hypothesis. Once the determination of probable Martian origin had been made, observations about the meteorites could be generalized to become probable observations about Mars. Efforts to do so are hampered to variable degrees by lack of knowledge of the geologic settings from whence the meteorites came. This is also true of the radiometric age data.

The young radiometric ages of shergottites, first observed for the type example, Shergotty, by Geiss and Hess (1958), were among the first lines of evidence cited in support of their origin on a planetary-sized body, probably Mars (Nyquist et al., 1979b; Wasson and Wetherill, 1979). However, some characteristics of the analytical data seemed to violate criteria developed for unambiguous interpretation of radiometric ages as igneous crystallizaton ages. In particular, the $\mathrm{Rb}-\mathrm{Sr}$ and ${ }^{39} \mathrm{Ar}-$ ${ }^{40} \mathrm{Ar}$ ages were discordant (Nyquist et al., 1979a; Bogard et al., 1979). Moreover, the Rb-Sr data showed considerable "scatter" about the best fit isochron. Thus, it did not initially appear possible to interpret the $\sim 165 \mathrm{Myr}$ Rb-Sr age of Shergotty, for example, as the crystallization age, particularly, since the ${ }^{39} \mathrm{Ar}-{ }^{40} \mathrm{Ar}$ age of a 
plagioclase separate was older at $\sim 250 \mathrm{Myr}$. Considerable experience with dating lunar samples had shown that although ${ }^{39} \mathrm{Ar}-{ }^{40} \mathrm{Ar}$ ages of bulk samples could be biased low due to diffusive loss of ${ }^{40} \mathrm{Ar},{ }^{39} \mathrm{Ar}-{ }^{40} \mathrm{Ar}$ ages of plagioclase separates generally gave reliable crystallization ages. Thus, the $\mathrm{Rb}-\mathrm{Sr}$ age was initially interpreted as likely reflecting the time of a thermal metamorphism. Because the shergottites were more highly shocked than almost all other meteorites or lunar samples, initial attention was given to post-shock thermal metamorphism as the agent for resetting both types of ages (Nyquist et al., 1979a; Bogard et al., 1979). It has since been established that neither post-shock thermal metamorphism nor shock transformations of mineral phases are adequate to reset the $\mathrm{Rb}-\mathrm{Sr}$ isotopic system. Thus, the possibility of shock resetting of the radiometric ages appears to have been a false lead.

Radiometric ages determined by other methods often were discordant also, and contributed to the confusion about the ages of shergottites. Here, it is sufficient to note that isotopic heterogeneities occurring within the rocks over distances of centimeters appear to complicate the isotopic data. For example, the existence of heterogeneity in initial ${ }^{87} \mathrm{Sr} /{ }^{86} \mathrm{Sr}$ between different samples of Zagami was shown by Nyquist et al. (1995). Papanastassiou and Wasserburg (1974) had observed a similar heterogeneity in initial ${ }^{87} \mathrm{Sr} /{ }^{86} \mathrm{Sr}$ for Nakhla much earlier. They took their observation as evidence that the $\mathrm{Rb}-\mathrm{Sr}$ age of $1.30 \pm 0.02 \mathrm{Gyr}$ that they determined separately for two samples of Nakhla was an age of metamorphism rather than an igneous crystallization age. (Here, as elsewhere in this paper, we use the value of the ${ }^{87} \mathrm{Rb}$ decay constant recommended by Minster et al. (1982); i.e., $\lambda_{87}=$ $1.402 \times 10^{-11} \mathrm{yr}^{-1}$ ). Gale et al. (1975) obtained apparently well-defined, concordant, isochrons for two additional samples of Nakhla. They interpreted the isochron age for their total data set, $1.23 \pm 0.01 \mathrm{Gyr}$, as the age of igneous crystallization. The present authors agree with that interpretation, but the issue of possible sample heterogeneity exists. The two samples studied by Papanastassiou and Wasserburg (1974) were obtained from separate sources, and weighed $0.7 \mathrm{~g}$ and $2.3 \mathrm{~g}$, respectively (D. Papanastassiou, personal communication). The samples studied by Gale et al. (1975), also from two different sources, weighed $13 \mathrm{~g}$ and $18 \mathrm{~g}$, respectively. It is possible that the larger samples used by Gale $e t$ al. (1975) effectively averaged out isotopic heterogeneity that could exist in Nakhla over small distances.

In spite of uncertainties in interpreting the isochron data, the early isotopic data of both Nakhla and Shergotty showed unambiguously that they were "young" by meteorite standards. For Nakhla, the evidence was $\mathrm{Rb}-\mathrm{Sr}$ model ages in the range of $2.5-3.6 \mathrm{Gyr}$, calculated relative to the initial ${ }^{87} \mathrm{Sr} /{ }^{86} \mathrm{Sr}$ of the solar system (Papanastassiou and Wasserburg, 1974; Gale et al., 1975). These model ages provide a strict upper limit to the formation age of Nakhla. The Rb-Sr model ages of shergottites are $\sim 4.5 \mathrm{Gyr}$, indicative of the time of chemical differentiation of their parent body. Nyquist et al. (1979b) found the Sm-Nd model ages of three shergottites relative to initial ${ }^{143} \mathrm{Nd} /{ }^{144} \mathrm{Nd}$ of the solar system to be only $\sim 2.8-3.6$ Gyr, however. These $\mathrm{Sm}-\mathrm{Nd}$ model ages also provide a strict upper limit to the formation ages 
of the meteorites, and they are especially remarkable in that they imply significant fractionation of the $\mathrm{Sm} / \mathrm{Nd}$ ratios of the meteorites from chondritic values, which normally is not achieved in "simple" magmatic processes. Thus, these young model ages clearly pointed to "late" and complex magmatic activity on the parent body of the shergottites.

Another feature of the shergottites that makes them somewhat unusual among stony meteorites is their relatively young cosmic ray exposure (CRE) ages. Such ages are determined from the accumulation of nuclides spalled from target nuclides in the meteorites by high energy cosmic ray interactions. Spallation nuclides that are stable against radioactive decay accumulate continually at production rates that are a function of the chemical composition of the meteorite and of changes in the energy spectrum of primary and secondary cosmic rays as a function of the size of the meteoroid and the depth of the meteorite within it. Spallation radionuclides that undergo radioactive decay accumulate only to equilibrium levels at which they decay at the same rate at which they are produced. The production rates of stable nuclides can be determined either theoretically using nuclear cross section data, or empirically from the equilibrium activities of closely related radionuclides for which the ratio of the production rate to that of the stable nuclide is known. Determination of stable noble gas CRE ages, for example, require mass spectrometric techniques similar to those required for ${ }^{39} \mathrm{Ar}^{-40} \mathrm{Ar}$ age dating, so stable noble gas $\mathrm{CRE}$ ages often are determined in the same investigations as those in which ${ }^{39} \mathrm{Ar}-$ ${ }^{40} \mathrm{Ar}$ ages are determined. An early study of four shergottites, Shergotty, Zagami, ALH77005, and EET79001 (Bogard et al., 1984) showed that, whereas three of them had very similar apparent exposure ages of $\sim 2-3 \mathrm{Myr}$, one (EET79001) had a much lower apparent exposure age, $<1 \mathrm{Myr}$. One possible explanation was that the actual exposure age of EET79001 was the same as that of the others, but that the production rate of stable nuclides was lower in EET79001 because it was located deeper in a large meteoroid, where the effective flux of primary cosmic rays was attenuated by about a factor of 3-4. A variation of this scenario is that EET79001 was initially part of a very large meteoroid, and was essentially totally shielded from cosmic rays for most of its lifetime in space. With acquisition of additional data for both stable and radionuclides, both of these explanations have fallen into disfavor. The currently accepted interpretation of the spallogenic nuclide data is that exposure to cosmic rays was initiated by excavation of the meteorites from depths on Mars that were completely shielded from the effects of cosmic rays, and thus that the CRE ages plus the time the meteorites have been on Earth give directly the time since they were ejected from Mars (cf. Eugster et al., 1997b). However, the young CRE age of EET79001 presents a problem when viewed in the context of its crystallization age, and its apparent relationship to the other shergottites.

Thus, the earlier interpretation of the $\mathrm{Rb}-\mathrm{Sr}$ and ${ }^{39} \mathrm{Ar}-{ }^{40} \mathrm{Ar}$ ages for shergottites of $\sim 180 \mathrm{Myr}$ and $\sim 250 \mathrm{Myr}$, respectively, as giving the time of shock metamorphism during their ejection from Mars as large blocks to be broken up in later secondary collisions ( $c f$. Shih et al., 1982) is no longer favored by the majority of 
of meteoriticists. Also, a steadily increasing number of Sm-Nd ages have been obtained that are concordant with the $\mathrm{Rb}-\mathrm{Sr}$ age for the same meteorite. Furthermore, ${ }^{39} \mathrm{Ar}-{ }^{40} \mathrm{Ar}$ ages can be explained by the presence of excess, non-radiogenic ${ }^{40} \mathrm{Ar}$ from a variety of sources. These problems have been much less acute for the other types of Martian meteorites, for which the ages are comparatively well defined.

The desire to find possible mechanisms for launching Martian meteorites and for metamorphic resetting of the radiometric ages of shergottites stimulated thorough investigations of their shock-metamorphic features. These shock features of the meteorites provide insight into the environment of the rocks when they were ejected from Mars. Furthermore, the original igneous textures of their minerals provide insight into the environments in which the rocks originally crystallized. For example, mineral textures are influenced by the cooling rate of the rock during crystallization, which in turn is influenced by the thickness of a magma flow. Thus, observable features in the meteorites themselves tell us some things about their geologic setting at key points in their histories.

Because the Martian meteorites are the only samples from Mars currently available for laboratory studies, their properties are of great importance to understand the formation and evolution of our neighboring planet. In this review we summarize their crystallization and cosmic ray exposure ages, compare the shock levels to which they have been exposed, and briefly consider the implications of those data for the meteorites' provenance and for Martian evolution. But, first we describe the mineralogical and geochemical characteristics of the meteorites themselves.

\section{Mineralogy, Petrography, and Geochemistry}

According to their mineralogical composition and textural characteristics, the Martian meteorites represent igneous rocks of basaltic and ultramafic provenance. They appear to have crystallized either in lava flows as volcanic rocks or in mafic, probably shallow, intrusions as plutonic ultramafic rocks. They are divided into shergottites, consisting of a basaltic and a lherzolitic subgroup, nakhlites (clinopyroxenites), chassignites (dunites), and orthopyroxenites. Chassigny and ALH84001 are the only dunite and orthopyroxenite in the latter two groups (Figure 1). In the following, we describe the mineralogy, petrography, and geochemistry of the various Martian meteorites. For more details, the reader is referred to the review article by McSween (1994) and to the Mars Meteorite Compendium (Meyer, 1998).

\subsection{Basaltic Shergottites}

The meteorites Shergotty, Zagami, EETA79001, QUE94201, Dar al Gani 476, and Los Angeles, as well as the recently found Dhofar 019 and Sayh al Uhaymir 005, belong to the group of basaltic shergottites. These rocks predominantly consist of augite and pigeonite, typically showing a strong irregular chemical zoning towards an Fe-rich rim, and of plagioclase in the form of shock-induced diaplectic 


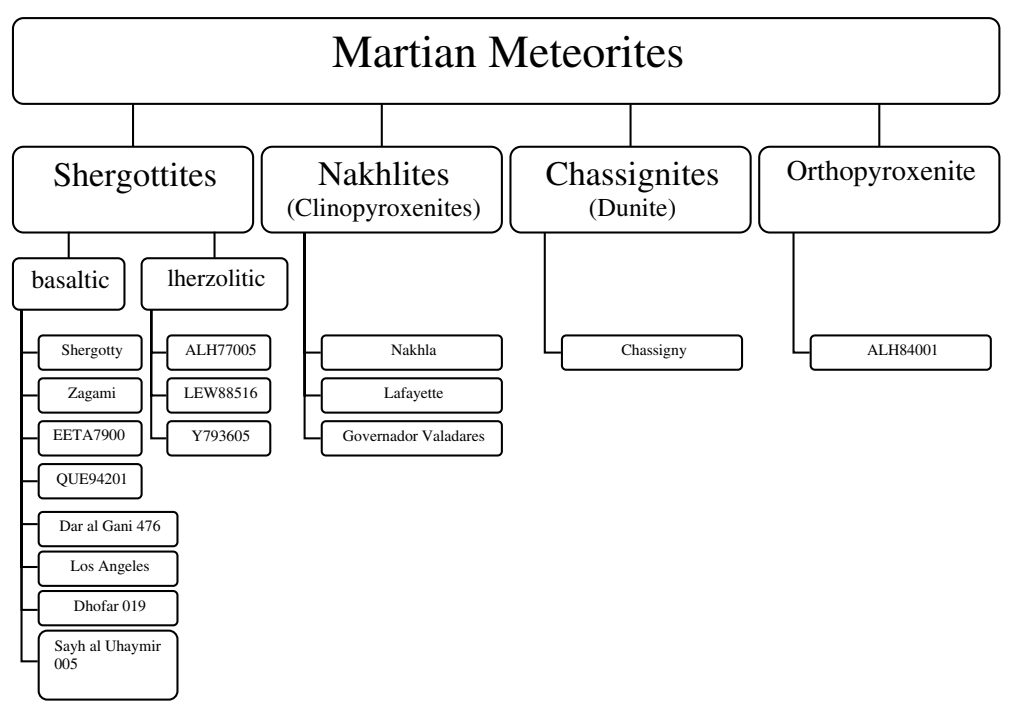

Figure 1. Classification of Martian meteorites (modified after Stephan et al., 1999).

glass (maskelynite). Minor components are pyrrhotite, whitlockite, ilmenite and titanomagnetite (McSween, 1994). Pyroxene often contains small rounded to subrounded melt inclusions of kaersutite, spinel, and sulfides in a Si-rich glassy or microcrystalline groundmass, interpreted as trapped original melt (e.g., Treiman, 1985). EETA79001 contains two basaltic lithologies, termed A and B. The main differences between these units are the small grain size and the occurrence of olivine xenocrysts, orthopyroxene, and chromite in lithology A. Besides formation by simple mixing of basaltic liquids, it was suggested that lithology A represents an impact melt (Mittlefehldt et al., 1997). Among the basaltic shergottites, only Dar al Gani 476 and Sayh al Uhaymir 005 have some similarities to lithology A of EETA79001, containing large xenocrysts of olivine set into a matrix of clinopyroxene and maskelynite (Zipfel et al., 2000; Grossman, 2000). The basaltic shergottites, except QUE94201 and Los Angeles, show a cumulate texture with mostly preferred orientations of the pyroxenes. However, the relatively small grain size of the pyroxenes and the petrographic similarities among the meteorites suggest that the alignment may have occurred by lava flow rather than by accumulation in a subsurface magma chamber (McCoy et al., 1992; McSween, 1994).

Compared to terrestrial basalts, the basaltic shergottites are characterized by a high $\mathrm{Fe} /(\mathrm{Fe}+\mathrm{Mg})$ ratio and low $\mathrm{Al}_{2} \mathrm{O}_{3}$ concentrations. All meteorites of this group have complex rare Earth element (REE) patterns with distinct depletions of light REE (LREE) but without a clear Eu anomaly. Except for water, all volatile elements are enriched (Wänke and Dreibus, 1988; Lodders, 1998; Zipfel et al., 2000; Rubin et al., 2000). Initial $\mathrm{Sr}, \mathrm{Nd}$, and $\mathrm{Pb}$ isotopic compositions are variable among the basaltic shergottites, possibly reflecting different stages of mixing Martian crust with an isotopically homogeneous magma. 


\subsection{Lherzolitic SHERGotTites}

Three shergottites (ALH77005, LEW88516, and Y-793605) are lherzolitic as they contain $<10 \mathrm{vol} \% \%$ plagioclase. They are composed of relatively coarse-grained anhedral to euhedral olivine and chromite enclosed by large orthopyroxene crystals (Harvey et al., 1993; McSween, 1994; Mikouchi and Miyamoto, 1997). Interstices are filled with accessory phases, i.e. maskelynite, pigeonite, augite, and whitlockite. The Fe-Mg-silicates of this suite of ultramafic rocks are much more magnesian than those of the basaltic shergottites, and an observed chemical disequilibrium between coexisting olivine and pyroxene gives evidence for non-linear cooling (Harvey et al., 1993). High concentrations of $\mathrm{Fe}^{3+}$ in chromites suggest high oxygen fugacity during crystallization. Similarly to the basaltic shergottites, the lherzolitic ones are depleted in LREE (Dreibus et al., 1982). However, the composition of radiogenic Sr isotopes in ALH77005 and LEW88516 shows that the two rocks crystallized from different magma sources (Borg et al., 1998a, 1998b).

\subsection{NAKHLITES}

The group of nakhlites contains the three clinopyroxenites Nakhla, Lafayette, and Governador Valadares. They consist of Mg-rich augite and Fe-rich olivine set into a microcrystalline groundmass of mostly radiating crystalline plagioclase, which has not been transformed into maskelynite by shock, pigeonite, ferroaugite, titanomagnetite, pyrite, troilite, chlorapatite, and sometimes $\mathrm{SiO}_{2}$-rich glass. In addition, they contain phyllosilicates (iddingsite) and evaporite mineral assemblages of secondary, but Martian, origin confirming the presence of liquid water on Mars (Gooding et al., 1991; Bridges and Grady, 2000; Swindle et al., 2000).

All three meteorites are cumulates, and lamellar inclusions of augite and magnetite in olivine from Nakhla and Governador Valadares confirm slow cooling under highly oxidizing conditions (Mikouchi and Miyamoto, 1998). In addition, olivine frequently contains small melt inclusions compositionally representing a major and distinct type of Martian magma.

All nakhlites have moderately high contents of volatiles and are enriched in LREE. The almost identical initial $\mathrm{Sr}$ and $\mathrm{Nd}$ isotopic composition of nakhlites is distinct from that of the shergottites, indicating that the two types of rocks formed from different parent magmas (Nakamura et al., 1982b; McSween, 1994).

\subsection{Chassigny}

Chassigny is the only dunite among the Martian meteorites, and consists of $90 \%$ Fe-rich olivine $\left(\mathrm{Fa}_{\sim 32}\right), 5 \%$ pyroxene, $2 \%$ feldspar $\left(\mathrm{An}_{\sim 20} ;\right.$ maskelynite), and $3 \%$ accessory phases (Floran et al., 1978). High concentrations of $\mathrm{Fe}^{3+}$ in chromite as well as lamellar exsolutions in olivine indicate crystallization at high oxygen fugacity and low cooling rates (Floran et al., 1978; Greshake et al., 1998). Its cumulus fabric indicates a fractional crystallization of a mafic magma body. 
Chassigny is enriched in LREE but shows no Eu anomaly. While this pattern is distinct from those of nakhlites, excluding a formation from the same magma, the initial Sr isotope compositions of Chassigny and nakhlites are identical (Nakamura et al., 1982a; McSween, 1994).

\subsection{ALH84001}

ALH84001 is a coarse-grained brecciated orthopyroxenite with a modal composition of $96 \%$ orthopyroxene, $2 \%$ chromite, $1 \%$ plagioclase (maskelynite), and $0.15 \%$ phospate. Accessory phases are augite, olivine, pyrite and Fe-Mg-Ca-carbonates (Mittlefehldt, 1994). Texturally, ALH84001 is dominated by up to $6 \mathrm{~mm}$ long orthopyroxene crystals joined at $120^{\circ}$ triple junctions and poikilitically enclosing $\mathrm{Fe}^{3+}$-rich euhedral chromites (Berkley and Boynton, 1992; Mittlefehldt, 1994; McSween, 1994). Maskelynite and rarely chromite occur interstitially between orthopyroxene. Predominantly along fractures and in cataclastic areas, compositionally strongly zoned carbonates are found, often forming characteristic globules that appear either as concentric spherules or as flat "pancakes" (e.g., McKay et al., 1996). Many carbonates resemble a "bull's-eye" with a center of dolomiteankerite surrounded by concentric bands of siderite, magnesite, and sulfide, but they come in a multitude of varieties (Scott et al., 1998). High-resolution Scanning Electron Microscope (SEM) images revealed worm-like features in the carbonates. Additionally, the morphologies of some magnetite grains in the carbonates resemble those formed by magnetotactic bacteria, and relatively high concentrations of polycyclic aromatic hydrocarbons (PAHs) have been found. From these observations, McKay et al. (1996) concluded early biologic activity was present on Mars. Meanwhile, various other non-biogenic formation mechanisms of the carbonates and magnetite assemblage have been proposed, including impact origin (Harvey and McSween, 1996; Scott et al., 1998; Scott, 1999) and flood-evaporite formation (McSween and Harvey, 1998; Warren, 1998). The high concentrations of PAHs, present in all textural units of ALH84001 (Stephan et al., 1998, 1999), could also be due to terrestrial contamination (Becker et al., 1997; Jull et al., 1998).

ALH84001 is depleted in the LREE and has a negative Eu anomaly. Its very low concentrations of siderophile elements led to the development of a model for the Martian mantle depleted in siderophile elements (Dreibus et al., 1994).

\subsection{ENVIRONMENTS OF IGNEOUS CRYSTALLIZATION}

\subsubsection{Basaltic Shergottites}

The textures of the basaltic shergottites are consistent with those expected for surface flows of basaltic lava. McCoy et al. (1992) suggested that Zagami was the product of a two-stage magmatic history. The first stage occurred in a slowly cooling magma chamber. The presence of amphibole in the cores of pyroxene crystals requires pressures equivalent to depths $>7.5 \mathrm{~km}$ on Mars. During the second stage, pyroxene crystals were entrained into a magma that either intruded to the 
near surface and cooled in a relatively thin dike or sill, or extruded to the surface and crystallized in a lava flow $>10 \mathrm{~m}$ thick. This two-stage scenario is consistent with observations of volcanic constructs and flows in the Tharsis region of Mars.

\subsubsection{Lherzolitic Shergottites}

Detailed investigations of lherzolitic textures revealed a preferred crystallographic orientation of olivine, proving that the lherzolitic shergottites are real cumulates, formed in a plutonic sub-surface environment (Berkley and Keil, 1981; McSween, 1994). Ikeda (1994) suggested that the compositional discontinuities among the four zoning types of chromite in ALH77005 arise from magma mixing in shallow magma reservoirs on Mars. Their crystallization histories, as reconstructed by Harvey et al. (1993) and McSween (1994), require varying degrees of prolonged cooling to allow olivine to reequilibrate at comparatively low temperature. On Earth, lherzolites crystallize either at depths of $>8 \mathrm{~km}$ (mantle rocks) or as cumulates in large magma chambers. Harvey et al. (1993) concluded that the trace element and minor element patterns of LEW88516 and ALH77005 minerals were essentially identical and consistent with large-volume, closed-system fractional crystallization followed by localized crystallization of isolated melt pockets.

\subsubsection{Nakhlites (Clinopyroxenites)}

The cumulate textures of the nakhlites, combined with the presence of lamellar inclusions of augite and magnetite, require slow cooling under highly oxidizing conditions. These textures, especially those of Nakhla and Governador Valadares, are analogous to those of terrestrial augite-rich igneous cumulate rocks of the Abitibi greenstone belt of northern Ontario (Treiman, 1987), where augite cumulates comprise the lower half of a $125 \mathrm{~m}$ thick flow. Augite cumulates in the middle third of a $300 \mathrm{~m}$ thick sill have little mesostasis, giving them textures more comparable to those of Lafayette. Treiman (1987) concluded from these comparisons that the nakhlites crystallized in thick flows, $>125 \mathrm{~m}$ thick, or in shallow intrusions, probably less than $1 \mathrm{~km}$ deep, of basaltic or picritic magmas. He noted that volcanoes with thick lava flows and evidence of shallow intrusions were common in the Tharsis region of Mars. Furthermore, greenstone belt volcanism may be related to mantle hot spots, another potential analogy to the Tharsis region.

\subsubsection{Chassigny (Dunite)}

The texture and high modal abundance of olivine suggest that Chassigny is a cumulate, also. Floran et al. (1978) described the crystallization history as similar to that of nakhlites, except that olivine is much more abundant, and chromite, absent from naklites, crystallizes early. These characteristics suggest that Chassigny and the nakhlites might represent different parts of the same or similar layered igneous complexes. From their REE abundances, Wadhwa and Crozaz (1994) concluded that they could not have crystallized from the same magma, however. 


\subsubsection{ALH84001 (Orthopyroxenite)}

Mittlefehldt (1994) interpreted the orthopyroxene and chromite in ALH84001 as cumulus phases. Their textural features indicate slow cooling either during magmatic crystallization, or metamorphic recrystallization, or both. Mineral compositions in ALH84001 are similar to those of lherzolitic shergottites or nakhlites. Mittlefehldt (1994) cited the uniform pyroxene compositions, unusual for Martian meteorites, as indicating that ALH84001 cooled more slowly than did the shergottites, nakhlites, or Chassigny; i.e., it formed at greater depth than they did. Kring and Gleason (1997) argued that the orthopyroxene-silica assemblage present in ALH84001 corresponded to magmatic temperatures of $\sim 1400-1470^{\circ} \mathrm{C}$, and to a static pressure of $\sim 0.5 \mathrm{GPa}$, equivalent to a depth of $\sim 40 \mathrm{~km}$ on Mars. Gleason et al. (1997) noted that its texture was reminiscent of those of cataclastic anorthosites from the ancient, heavily-cratered, lunar highlands. They, like Treiman (1995b), suggested that at least some of the secondary carbonate formed by replacement of plagioclase, and cite textural evidence as showing this occurred after plagioclase had been converted to maskelynite. Kring et al. (1998) concurred in that suggestion, noting that it implied formation of the carbonate after $3.92 \pm 0.04 \mathrm{Gyr}$ ago, the time of Ar-degassing of plagioclase according to Turner et al. (1997). However, Scott (1999) alternatively suggested that the original carbonates formed as evaporite deposits, probably prior to impact heating $\sim 4 \mathrm{Gyr}$ ago, when episodic floods were more common. He suggests that preservation of the carbonates for $\sim 4$ Gyr was aided by the impact, which sealed up the carbonate-bearing fractures and pores, making the rock less pervious to later infiltration of fluids.

\section{Shock Metamorphism}

\subsection{EVIDENCE OF SHOCK}

It is generally agreed that the Martian meteorites have been ejected from the planet's surface by large-scale impacts. The ejection velocity must have exceeded the escape velocity of Mars, which is about $5 \mathrm{~km} / \mathrm{s}$. Material accelerated by a shock wave to $>5 \mathrm{~km} / \mathrm{s}$ should be in a molten state according to basic shock wave physics. The fact that all known Martian meteorites are solid though strongly shocked rock fragments prompted Melosh (1984) to develop a model of the ejection process in which a special spallation mechanism provides most of the required ejection velocity for rock fragments ejected from a thin, uppermost layer of the impacted target without melting them. Although alternative mechanisms have been proposed (Nyquist, 1983; O'Keefe and Ahrens, 1986), this model has been widely accepted. The originally proposed spallation mechanism (Melosh, 1984) required the parent craters of the meteorites to be larger than $\sim 10 \mathrm{~km}$ in diameter. Recent refinements of the model have reduced the size limit to $>3 \mathrm{~km}$ (Head and Melosh, 2000).

As expected from the impact and ejection model for the origin of the Martian meteorites, the imposed extreme physical conditions caused significant changes in 
the textures, mineralogy, and possibly even the isotopic compositions of constituent mineral phases. It even led to a shock- induced implantation of Martian atmospheric gases into the meteorites (Duke, 1968; Stöffler et al., 1986; Bogard et al., 1986; Wiens and Pepin, 1988; McSween, 1994). The important obervation is that all Martian meteorites are moderately to strongly shock metamorphosed by shock pressures ranging between about 15 and $45 \mathrm{GPa}$. The understanding of the type and intensity of shock metamorphism of Martian meteorites is thus essential for the interpretation of the ejection and possible impact-induced relocation processes, which relate to some extent to the problem of the geological provenance, and to the interpretation of analyzed isotope systems, which may be disturbed by shock.

It has been recognized since the pioneering studies of Tschermak (1872) that shergottites and some other achondrites are severely shocked (Binns, 1967; Duke, 1968). Although shock effects in meteorites were known before the Martian origin of the SNC meteorites was suspected (e.g., Wood and Ashwal, 1981), the Martian origin hypothesis gave new impetus to their study. The degree of shock metamorphism in shergottites was first studied quantitatively on Shergotty (Lambert and Grieve, 1984; Stöffler et al., 1986). In all shergottites the constituent minerals display specific, more or less similar shock effects, well known from naturally and experimentally shocked terrestrial, lunar, and meteoritic rocks (Stöffler, 1972; Stöffler et al., 1988; Bischoff and Stöffler, 1992). Pyroxene shows strong mosaicism, mechanical twinning, shear fractures and various lattice defects such as high dislocation densities revealed in the Transmission Electron Microscope (TEM; e.g., Müller, 1993). Olivine, if present, is affected by strong mosaicism, deformation bands, planar fractures, planar deformation features and high dislocation densities (e.g., Greshake and Stöffler, 1999, 2000). Ostertag et al. (1984) attributed the brown staining of olivine in ALH77005 to a shock-induced oxidation of iron to $\mathrm{Fe}^{3+}$. Plagioclase is transformed to diaplectic glass (maskelynite) and retains its primary crystal shape. Based on the experimentally calibrated refractive index of maskelynite, the peak shock pressure (final equilibrium shock pressure) of the host meteorite can be deduced (Stöffler et al., 1986).

A typical feature of the shergottites is the presence of shock-produced veins and melt pockets caused by local pressure and temperature excursions of presumably up to $60-80 \mathrm{GPa}$ and $2000^{\circ} \mathrm{C}$ (Stöffler et al., 1986). These pressure estimates are based on experimental data (Kieffer et al., 1976; Schaal and Hörz, 1977; Schmitt, 2000). In addition, high pressure phases such as very dense post-stishovite polymorphs of $\mathrm{SiO}_{2}$ have been discovered in Shergotty (Sharp et al., 1999; El Goresy et al., 2000). It has to be pointed out that these high pressures were only produced very locally and do not represent the equilibration pressure as previously suggested (Sharp et al., 1999). Recently, an assemblage of omphacite, stishovite and $\mathrm{KAlSi}_{3} \mathrm{O}_{8}$-hollandite was found in a shock vein of Zagami, indicating crystallization of these phases during decompression between 25 and $50 \mathrm{GPa}$ (Langenhorst and Poirier, 2000). Also, the high-pressure polymorphs of olivine and pyroxene, ringwoodite and majorite, were tentatively reported from a melt vein in the basaltic 
shergottite EETA79001 (Steele and Smith, 1982). However, unambiguous identification of these two phases has failed so far (Boctor et al., 1998). Moreover, the melt pockets in some Martian meteorites are obviously the host regions of gases of the Martian atmosphere that were first detected in EETA79001 (Bogard and Johnson, 1983; Becker and Pepin, 1984). These gases must have been implanted during shock metamorphism of the meteorite precursor rocks near the Martian surface. Experimental studies on shock implantation show that shock can relatively easily incorporate an ambient gas phase into solid material, even at temperatures well below melting (Bogard et al., 1986; Wiens and Pepin, 1988).

Refractive index measurements of maskelynite gave quantitative estimates of the peak shock pressure for some shergottites: Shergotty: $29 \pm 1$ GPa (Stöffler $e t$ al., 1986), Zagami: $31 \pm 2$ GPa (Stöffler et al., 1986; Langenhorst et al., 1991), EET79001: $34 \pm 2$ GPa (Lambert, 1985), ALH77005: $43 \pm 2$ GPa (McSween and Stöffler, 1980). For other shergottites the values, based on the overall shock effects in plagioclase, olivine, and pyroxene, and on the presence and abundance of localized melts, are less accurate: Dar al Gani 476: probably 30-35 GPa (Greshake and Stöffler, 1999, 2000), QUE94201: 30 - 35 GPa, Los Angeles: 35 - 40 GPa, Dhofar 019: 35 - $40 \mathrm{GPa}$, Sayh al Uhaymir: 35 - $40 \mathrm{GPa}$, LEW88516: ca. 40 - $45 \mathrm{GPa}$ ("strongly shocked", Keller et al., 1992), Y793605: ca. 40 - 45 GPa. All estimated peak shock pressures of shergottites are summarized in Table I, along with the estimated post-shock temperatures.

Considering the range of shock pressures observed in shergottites, it is conspicuous that the basalts were all affected by similar shock pressures in the range of $\sim 30-35 \mathrm{GPa}$, whereas the lherzolites reveal somewhat higher shock pressure ( $\sim 40$ - $45 \mathrm{GPa}$ ). Also, Ott and Löhr (1992) noted that the ${ }^{4} \mathrm{He}$ content of lherzolite LEW88516 indicates complete loss of radiogenic ${ }^{4} \mathrm{He}$ acquired prior to its ejection from Mars $\sim 3 \mathrm{Myr}$ ago, consistent with its high post-shock temperature of $\sim 600^{\circ} \mathrm{C}$ (Table I). The type and homogeneity of shock damage observed in the constituent minerals of the basaltic shergottites indicates that each of them was affected by only one impact event (Stöffler et al., 1986; Müller, 1993). This seems to be different for the lherzolitic shergottites, as observed for Y793605, which has been brecciated by a first impact and shock metamorphosed by a second impact. The three nakhlites are less intensely affected by shock metamorphism than the other Martian meteorites. Only weak undulatory extinction and a rather low dislocation density in olivine as well as entirely birefringent plagioclase suggest a peak shock pressure of $\sim \leq 20 \pm 5 \mathrm{GPa}$ (Bunch and Reid, 1975; Greshake, 1998).

Shock metamorphism in Chassigny was investigated in detail by optical and transmission electron microscope (Langenhorst and Greshake, 1999). Conversion of feldspars to diaplectic glass (maskelynite), the clino-/orthoenstatite inversion, strong mosaicism of olivine, and the activation of numerous planar fractures and cdislocations in olivine are among the shock effects. High-resolution TEM revealed additionally the coexistence of planar fractures with discontinuous fractures in olivine. These findings point to a shock pressure of about $35 \mathrm{GPa}$. 
TABLE I

Estimates of the peak shock pressure (final equilibration shock pressure) and the overall post-shock temperature increase in Martian meteorites. Data from Stöffler et al. (1986) and Stöffler (2000) except for Sayh al Uhaymir 005, Los Angeles, and Dhofar (this paper).

\begin{tabular}{lll}
\hline Meteorite & Shock pressure $(\mathrm{GPa})$ & Post-shock temperature* $^{*}$ \\
\hline Shergotty & $29 \pm 1$ & $200 \pm 20$ \\
Zagami & $31 \pm 2$ & $220 \pm 50$ \\
EETA 79001 & $34 \pm 2$ & $250 \pm 50$ \\
QUE94201 & $\sim 30-35$ & $\sim 200-350$ \\
Dar al Gani 467 & $\sim 35-40$ & $\sim 350-450$ \\
Los Angeles & $\sim 35-40$ & $\sim 350-450$ \\
Dhofar 019 & $\sim 35-40$ & $\sim 350-450$ \\
Sayh al Uhaymir 005 & $\sim 35-40$ & $\sim 350-450$ \\
ALHA77005 & $43 \pm 2$ & $\sim 450-600$ \\
LEW88516 & $\sim 45$ & $\sim 600$ \\
Y793605 & $\sim 45$ & $\sim 600$ \\
ALH84001 & $\sim 35-40$ & $\sim 300-400$ \\
Nakhlites & $\sim 20( \pm 5)$ & $\sim 100$ \\
Chassigny & $\sim 35$ & $\sim 300$ \\
\hline
\end{tabular}

${ }^{*}$ Relative to ambient pre-shock temperature.

In the orthopyroxenite ALH84001, shock metamorphism is documented by complex textures, such as localized brecciation in fine-grained shear zones, strong mosaicism and numerous irregular fractures in orthopyroxene, and by the conversion of all plagioclase to maskelynite. While Mittlefehldt (1994) explained these effects by a single impact event, Treiman (1998) invoked up to five impacts. We believe that the presence of maskelynite in both brecciated and non-brecciated regions indicates that at least two impact events are required: A first weak shock event producing the brecciation and a subsequent stronger shock event which transformed plagioclase to maskelynite throughout the whole rock.

\subsection{ENVIRONMENTS AND IMPLiCATIONS OF SHOCK METAMORPhiSM}

The observed shock metamorphism of Martian meteorites has important implications for their impact and ejection history and for their geologic provenance, if the geologic settings of their magmatic formation processes are taken into account. Summarizing the essential observations leads us to some general conclusions.

All Martian meteorites are moderately to severely shocked (Table I, Figure 7), with effects being homogeneously distributed throughout the rocks. These shock effects can be attributed to one specific event in each case, most probably the 
ejection event. A single stage shock history is implied for all basaltic shergottites and most likely for the nakhlites and for Chassigny. However, some of the ultramafic "plutonic" rocks such as lherzolitic shergottite Y-793605 and orthopyroxenite ALH84001 are shocked monomict breccias indicating a two-stage shock history: In a first impact, the rocks are brecciated at very low shock pressure at depth and relocated to the surface during the same event as commonly observed in terrestrial impact craters such as the Ries (e.g., Pohl et al., 1977). The transformation of plagioclase to maskelynite indicates strong shock metamorphism in a second impact, most probably the ejection event. Although clear evidence for the two remaining lherzolitic basalts and for the nakhlites/chassigny group is unavailable, an impact-induced relocation of the "plutonic" ultramafic Martian meteorites from their primary deep-seated magmatic setting is highly plausible.

The second fundamental observation relates to the ranges of observed shock pressures for all the Martian meteorites and for particular groups of them (Table I, Figure 7). Although exact values are not yet available, we recognize 1) that the observed shock pressures are restricted to a range of about 15 to $45 \mathrm{GPa}$, and 2) that the basaltic shergottites range from about 30 to $35 \mathrm{GPa}$, the lherzolitic shergottites from about 40 to $45 \mathrm{GPa}$, and the nakhlites from about 15 to $25 \mathrm{GPa}$. This means that unshocked meteorites as well as shock-fused meteorites are lacking and that the observed 15-45 GPa range may be viewed as a typical "launch window" for Mars. The lower limit may indicate that unshocked rocks and rocks shocked to pressures lower than the Hugoniot Elastic Limit cannot be ejected, in contrast to what has been proposed by Melosh (1995), Mileikowsky et al. (2000), and Weiss et al. (2000). The upper limit indicates that melt ejecta are too much dispersed and, hence, too small to survive as meteoroids. Comparing meteorites from Mars, the Moon, and the eucrite parent body, it seems that the observed range of shock metamorphism related to the ejection event is a function of the size of the parent planetary body and therefore of the magnitude of the escape velocity: The present data indicate that lunar meteorites are shocked below about $20 \mathrm{GPa}$ (Bischoff and Stöffler, 1992; Greshake et al., 2001), and meteorites of the eucrite-howarditediogenite group, possibly originating from the $550 \mathrm{~km}$ diameter asteroid Vesta, are at most mildly shocked, i.e. below $\sim 5-10 \mathrm{GPa}$ (Metzler et al., 1995).

A third implication of the observed shock metamorphism of Martian meteorites relates to the size of the precursor meteoroids and to their ejection ages. As known from terrestrial craters such as the Ries crater (Pohl et al., 1977; Stöffler and Ostertag, 1983; von Engelhardt and Graup, 1984), the size of displaced shocked rock fragments is inversely proportional to the shock intensity. Crystalline rock fragments in polymict breccias of the Ries shocked to the range of the Martian shergottites $(\sim 30-45 \mathrm{GPa})$ do not exceed $0.5 \mathrm{~m}$ or so, and most sizes are $\sim 0.1-10 \mathrm{~cm}$. Typical shock stage III rocks ( $45-60 \mathrm{GPa}$; Stöffler, 1984) are consistently $<50 \mathrm{~cm}$ in size. Additionally, distal ejecta (solid clasts) in the Ries (Reutter blocks: Upper Jurassic limestone fragments, Pohl et al., 1977) are not only small, $<\sim 20 \mathrm{~cm}$, but are also derived from the uppermost layer of the target in agreement with 
the conditions invoked by the spallation model (Melosh, 1984). Consequently, the lherzolitic shergottites ( $40-45 \mathrm{GPa}$ ) must have originated from $\approx 0.1 \mathrm{~m}$-sized rocks and cannot have been ejected in one block together with those basaltic shergottites that have the same ejection age (Figure 7a). Rather, the basalts and lherzolites may be derived from different surface regions of the same parent crater notwithstanding the fact that the lherzolites had to be relocated first to the surface by a previous impact. A similar case could be made for the nakhlites and Chassigny, which also have identical ejection and crystallization ages but different shock pressures.

The peak shock pressures experienced by the Martian meteorites are likely to be a consequence of their geometrical relationship to "ground zero" at the moment of the impact that is destined to launch them from the planet. The near-surface spall model, for example, outlines rather definite relationships between the impactor, the transient crater cavity, and the target region near ground zero (Melosh, 1984; Figure 11). Those fragments destined for ejection might be considered to constitute the "lid" of the transient cavity; a lid destined to be blown off. In the spallation model, the thickness of the "lid" is given by the depth of the spall zone, and was estimated by Warren (1994) to be $0.2-0.4$ times the diameter of the projectile at a distance of $1-3$ projectile radii from the the impact. Thus, the "lid" would be on the order of 50 to $100 \mathrm{~m}$ thick for a $10 \mathrm{~km}$ diameter crater. (See "Potential source terrains" later in the paper). In the lid, peak shock pressure increases in the downward direction from the surface, and decreases in the radial direction from ground zero. The nakhlites, being most lightly shocked, are thus implied to have been ejected from nearest the Martian surface, in spite of having probably crystallized near the center of a thick flow, $>\sim 100 \mathrm{~m}$ thick, or in a subsurface intrusion. Chassigny, being more severely shocked, is implied to have been ejected from a deeper region of the lid, if the nakhlites and Chassigny were ejected simultaneously. The lherzolitic shergottites are most highly shocked of all the Martian meteorites, and thus are expected to come from deep within the lid, close to the melt zone. If, for example, they and the basaltic shergottites were ejected simultaneously, the latter would have come from nearer to the surface, consistent with being recent lava flows. The orthopyroxenite ALH84001, which likely crystallized at the greatest depth of the Martian meteorites, experienced peak shock pressure equivalent to those of the shergottites, implying prior excavation from depth to the launch site. This is consistent with an ancient age and origin in the Martian highlands, which probably were "gardened" to depths on the order of a kilometer, or more (W. Hartmann, personal communication). Gardening of the surfaces of $\sim 180 \mathrm{Myr}$ old basaltic shergottite lava should have been minimal, however, and shergottites are likely to have been ejected from their place of emplacement as lava flows.

Finally, we note that rocks of distinctly different shock pressures, e.g. nakhlites and Chassigny, or basaltic and lherzolitic shergottites, cannot have been ejected from Mars in one large rock unit. Such scenarios have been proposed in order to explain the different exposure ages within the shergottite group as due to later break-up in space. Indeed, the limited size of strongly shocked rocks ejected from 


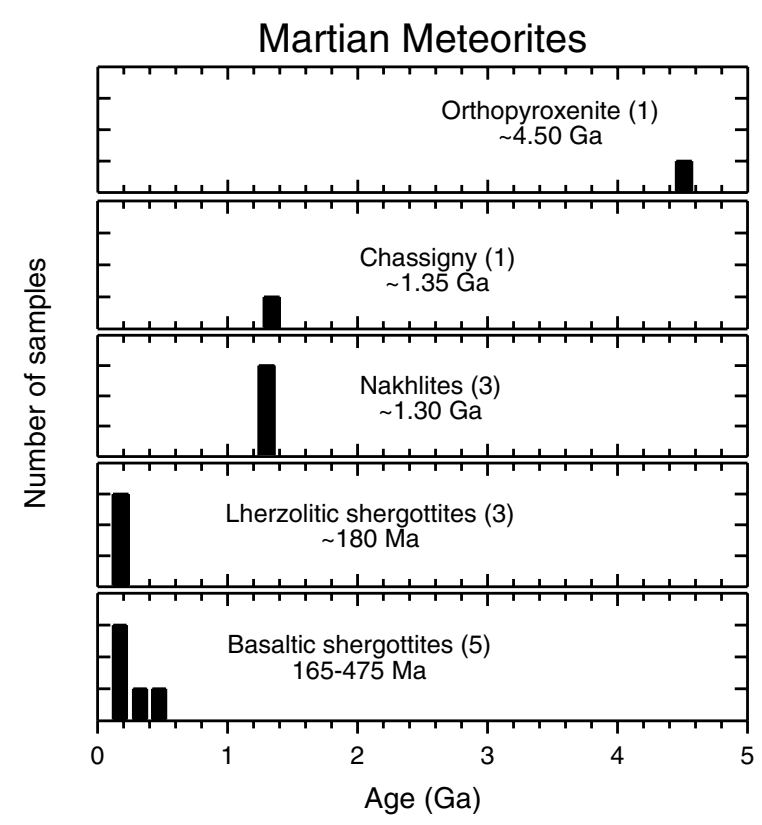

Figure 2. The crystallization ages of Martian meteorites separated by compositional group. The values plotted are the "preferred ages" from Tables II and III. The oldest meteorite in the Martian clan is $\sim 4.5$ Gyr old, and the youngest $\sim 180 \mathrm{Myr}$ old. Thus, Martian magmatism appears to have extended over most of solar system history, a conclusion that agrees with the time span of crater retention ages (Hartmann and Berman, 2000). The thirteen meteorites fall into only five age groups, leaving large gaps in Martian chronology as recorded by the meteorites.

the parent crater (see above) also argues against this possibility. In the case of the basaltic shergottites, however, the peak shock pressures are nearly equivalent, leaving the comparatively large size required of the initial ejecta fragments as the primary physical limitation on secondary break-up scenarios. In later sections, we will further discuss the issue of the number of required ejection events, in conjunction with the problem of the geological provenance of the Martian meteorites.

\section{Radiometric Ages}

Radiometric ages of Martian meteorites as reported in the literature are given in Tables II and III. We discuss the ages of individual meteorites within each of the meteorite classes separately. For the nakhlites and Chassigny (Table II), the ages determined by the various radiometric methods are in close agreement and present a coherent picture of when those rocks crystallized as thick magma flows or subsurface sills. For the other classes of Martian meteorites, notably the shergottites (Table III), the picture is more complicated.

Figure 2 gives an overview of those data that most reliably give the crystallization ages of the meteorites. The 13 meteorites define only 5 separate ages, covering 
TABLE II

Summary of Radiometric Ages of Martian Meteorites: Nakhlites, Chassigny, ALH84001

\begin{tabular}{|c|c|c|c|c|c|c|}
\hline Meteorite & $\begin{array}{l}\text { K-Ar } \\
(\mathrm{Gyr})\end{array}$ & $\begin{array}{l}{ }^{39} \mathrm{Ar}-{ }^{40} \mathrm{Ar} \\
(\mathrm{Gyr})\end{array}$ & $\begin{array}{l}\mathrm{Rb}-\mathrm{Sr} \\
(\mathrm{Gyr})\end{array}$ & $\begin{array}{l}\text { Sm-Nd } \\
(\mathrm{Gyr})\end{array}$ & $\begin{array}{l}\text { U-Th-Pb } \\
\text { (Gyr) }\end{array}$ & $\begin{array}{l}\text { Preferred } \\
\text { Age (Gyr) }\end{array}$ \\
\hline \multicolumn{7}{|c|}{ Clinopyroxenites (Nakhlites): } \\
\hline Nakhla & $1.30 \pm 0.03^{\mathrm{a}}$ & $1.3^{\mathrm{b}}$ & $\begin{array}{l}1.23 \pm 0.01^{\mathrm{c}} \\
1.30 \pm 0.02^{\mathrm{e}} \\
1.36 \pm 0.02^{\mathrm{e}}\end{array}$ & $1.26 \pm 0.07^{\mathrm{d}}$ & $\begin{array}{l}1.28 \pm 0.05^{\mathrm{d}} \\
1.24 \pm 0.11^{\mathrm{d}}\end{array}$ & $1.27 \pm 0.01$ \\
\hline Governador & & $1.32 \pm 0.04^{\mathrm{f}}$ & $1.32 \pm 0.01^{\mathrm{g}}$ & $1.37 \pm 0.02^{\mathrm{h}}$ & & $1.33 \pm 0.01$ \\
\hline Valadares & & & $1.19 \pm 0.02^{\mathrm{h}}$ & & & \\
\hline Lafayette & & $1.33 \pm 0.03^{\mathrm{b}}$ & $1.25 \pm 0.08^{\mathrm{i}}$ & $1.32 \pm 0.05^{\mathrm{I}}$ & & $1.32 \pm 0.02$ \\
\hline Dunite: & & & & & & \\
\hline Chassigny & $1.39 \pm 0.17^{\mathrm{j}}$ & $1.32 \pm 0.07^{\mathrm{k}}$ & $1.22 \pm 0.01^{1}$ & $1.36 \pm 0.06^{\mathrm{m}}$ & & $1.34 \pm \mathbf{0 . 0 5}$ \\
\hline \multicolumn{7}{|c|}{ Orthopyroxenite: } \\
\hline \multicolumn{7}{|l|}{ ALH 84001} \\
\hline Silicates & & $\begin{array}{l}3.92 \pm 0.10^{\mathrm{n}} \\
4.07 \pm 0.04^{\mathrm{o}} \\
4.10 \pm 0.20^{\mathrm{p}}\end{array}$ & $\begin{array}{l}4.55 \pm 0.30^{\mathrm{q}} \\
3.89 \pm 0.05^{\mathrm{r}}\end{array}$ & $\begin{array}{l}\sim 4.56^{\mathrm{s}} \\
4.50 \pm 0.12^{\mathrm{q}}\end{array}$ & & $4.51 \pm 0.11$ \\
\hline Carbonates & & $\sim 3.6^{t}$ & $\begin{array}{l}3.90 \pm 0.04^{\mathrm{u}} \\
1.41 \pm 0.10^{\mathrm{r}}\end{array}$ & & $4.04 \pm 0.10^{\mathrm{u}}$ & $3.92 \pm 0.04$ \\
\hline
\end{tabular}

References: ${ }^{a}$ Stauffer (1962); ${ }^{b}$ Podosek (1973); ${ }^{c}$ Gale et al. (1975); ${ }^{d}$ Nakamura et al. (1982a); ${ }^{e}$ Papanastassiou and Wasserburg (1974); ${ }^{f}$ Bogard and Husain (1977); ${ }^{g}$ Wooden et al. (1979); ${ }^{h}$ Shih et al. (1999); ${ }^{i}$ Shih et al. (1998); ${ }^{j}$ Lancet and Lancet (1971); ${ }^{k}$ Bogard and Garrison (1999); ${ }^{l}$ Nakamura et al. (1982b); ${ }^{m}$ Jagoutz (1996); ${ }^{n}$ Turner et al. (1997); ${ }^{o}$ Ilg et al. (1997); ${ }^{p}$ Bogard and Garrison (1999); ${ }^{q}$ Nyquist et al. (1995); ${ }^{r}$ Wadhwa and Lugmair (1996); ${ }^{s}$ Jagoutz et al. (1994); ${ }^{t}$ Knott et al. (1996); ${ }^{u}$ Borg et al. (1999).

an age span from the formation of the planet extending nearly to the present day, and there is only a single Martian rock older than 1.3 Gyr. This is a rather incomplete sample of the ages of Martian surface rocks, and these ages only give a record of Martian evolution, if their geologic context is known. Isotopic data of Martian meteorites are most useful to study the Martian global geochemical evolution.

Radiometric ages, though, provide absolute calibration marks for relative ages from cratering records. By extrapolating the lunar cratering rate to Mars, the relative ages of Martian surface units can be estimated from the density of craters on them (Neukum et al., 2001; Ivanov, 2001; Hartmann and Neukum, 2001). These ages are divided into three major chronostratigraphic units, or epochs: Noachian, Hesperian, and Amazonian. The Noachian and Amazonian are further subdivided into Early, Middle, and Late periods; whereas the Hesperian is simply divided into Early and Late periods (Tanaka, 1986; Tanaka et al., 1992). We begin our discussion with early Mars, working towards the present day. 
TABLE III

Summary of Radiometric Ages of Martian Meteorites: Shergottites

\begin{tabular}{|c|c|c|c|c|c|c|}
\hline Meteorite & $\begin{array}{l}\text { K-Ar } \\
(\mathrm{Myr})\end{array}$ & $\begin{array}{l}{ }^{39} \mathrm{Ar}-{ }^{40} \mathrm{Ar} \\
(\mathrm{Myr})\end{array}$ & $\begin{array}{l}\mathrm{Rb}-\mathrm{Sr} \\
(\mathrm{Myr})\end{array}$ & $\begin{array}{l}\text { Sm-Nd } \\
(\mathrm{Myr})\end{array}$ & $\begin{array}{l}\text { U-Th-Pb } \\
\text { (Myr) }\end{array}$ & $\begin{array}{l}\text { Preferred } \\
\text { Age }(\mathrm{Myr})\end{array}$ \\
\hline \multicolumn{7}{|c|}{ Shergottittes (Basalts): } \\
\hline Shergotty & $\begin{array}{l}580 \pm 50^{\mathrm{a} 1} \\
196 \pm 40^{\mathrm{w}}\end{array}$ & $\begin{array}{l}254 \pm 10^{\mathrm{b}} \\
167^{\mathrm{c}}\end{array}$ & $\begin{array}{l}163 \pm 12^{\mathrm{d}} \\
165 \pm 4^{\mathrm{e}}\end{array}$ & $\begin{array}{l}147 \pm 20^{\mathrm{e}} \\
360 \pm 16^{\mathrm{e}} \\
620 \pm 171^{\mathrm{f}}\end{array}$ & $\begin{array}{l}200 \pm 4^{\mathrm{g}} \\
437 \pm 36^{\mathrm{g}} \\
600 \pm 20^{\mathrm{g}} \\
217 \pm 110^{\mathrm{h}} \\
189 \pm 83^{\mathrm{h}}\end{array}$ & $165 \pm 4$ \\
\hline Zagami & & $242^{\mathrm{c}}$ & $\begin{array}{l}178 \pm 3^{\mathrm{f}} \\
174 \pm 14 \mathbf{i} \\
163 \pm 19^{\mathrm{i}}\end{array}$ & $163 \pm 7^{i}$ & $\begin{array}{l}230 \pm 5^{\mathrm{g}} \\
229 \pm 8^{\mathrm{g}}\end{array}$ & $177 \pm 3$ \\
\hline Los Angeles & & & $165 \pm 11^{\mathrm{j}}$ & $172 \pm 8^{\mathrm{j}}$ & & $170 \pm 8$ \\
\hline EETA79001A & & $2035^{\mathrm{c}}$ & $172 \pm 18^{\mathrm{k}}$ & & $\begin{array}{l}150 \pm 15^{\mathrm{g}} \\
170 \pm 36^{\mathrm{g}}\end{array}$ & $173 \pm 3$ \\
\hline EETA79001B & & & $\begin{array}{l}177 \pm 12^{\mathrm{k}} \\
173 \pm 3^{1}\end{array}$ & $165 \pm 43^{1}$ & & \\
\hline QUE94201 & & $730^{\mathrm{c}}$ & $327 \pm 12^{\mathrm{m}}$ & $327 \pm 19^{\mathrm{m}}$ & & $327 \pm \mathbf{1 0}$ \\
\hline DaG476 & & & & $\begin{array}{l}474 \pm 11^{\mathrm{n}} \\
\sim 800^{\circ}\end{array}$ & & $474 \pm 11$ \\
\hline \multicolumn{7}{|c|}{ Shergottites (Lherzolites) : : } \\
\hline ALHA77005 & $1330 \pm 130^{\mathrm{p}}$ & $3500^{\mathrm{c}}$ & $\begin{array}{l}156 \pm 6^{\mathrm{q}} \\
188 \pm 11^{\mathrm{f}} \\
185 \pm 11^{\mathrm{r}}\end{array}$ & $173 \pm 7^{r}$ & & $179 \pm 5$ \\
\hline LEW88516 & $2600^{\mathrm{c}}$ & & $183 \pm 10^{\mathrm{s}}$ & $166 \pm 16^{\mathrm{t}}$ & $\sim 170^{\mathrm{u}}$ & $\mathbf{1 7 8} \pm \mathbf{8}$ \\
\hline Y793605 & & $1595^{\mathrm{c}}$ & & & $212 \pm 62^{v}$ & $212 \pm 62$ \\
\hline
\end{tabular}

References: ${ }^{a 1}$ Geiss and Hess (1958), recalculated to the K-decay constants by Steiger and Jäger (1977); ${ }^{a}$ Eugster et al. (1997a); ${ }^{b}$ Bogard et al. (1979); ${ }^{c}$ Bogard and Garrison (1999); ${ }^{d}$ Nyquist $e t$ al. (1979a); ${ }^{e}$ Jagoutz and Wänke (1986); ${ }^{f}$ Shih et al. (1982); ${ }^{g}$ Chen and Wasserburg (1986); ${ }^{h}$ Sano et al. (2000); ${ }^{i}$ Nyquist et al. (1995); ${ }^{j}$ Nyquist et al. (2000); ${ }^{k}$ Nyquist et al. (1986); ${ }^{l}$ Nyquist $e t$ al. (2001); ${ }^{m}$ Borg et al. (1997); ${ }^{n}$ Borg et al. (2000); ${ }^{o}$ Jagoutz et al. (1999), Jagoutz and Jotter (2000); ${ }^{p}$ Miura et al. (1995); ${ }^{q}$ Jagoutz (1989); ${ }^{r}$ Borg et al. (2001b); ${ }^{s, t}$ Borg et al. (1998a, 1998b); ${ }^{u}$ Chen and Wasserburg (1993); ${ }^{v}$ Misawa et al. (1997); ${ }^{w}$ Terribilini et al. (1998).

\subsection{Orthpyroxenite AlH84001: A Carbonate-Bearing Fragment OF THE NOACHIAN CRUST}

ALH84001 is the only meteorite from the ancient Martian crust. We infer its crustal origin from its ancient age, and less directly from its composition. The old crystallization age of ALH84001 is direct evidence that portions of the Martian crust formed quickly after the planet accreted. There have been some variations in the ages reported for ALH84001 (Figure 3). Jagoutz et al. (1994) argued that the Sm- 


\section{Age of Orthopyroxenite ALH84001}

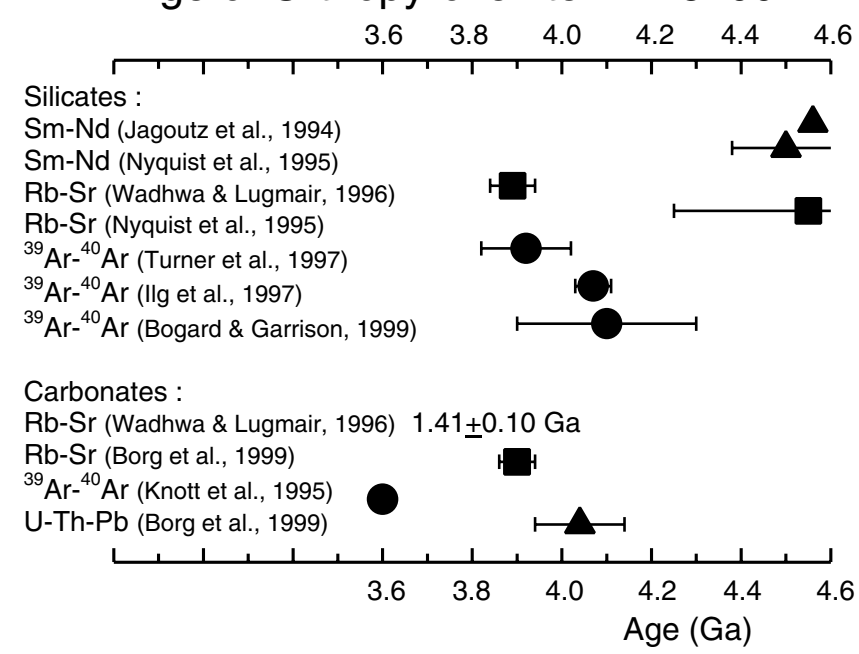

Figure 3. Radiometric ages of orthopyroxenite ALH84001, as determined by a variety of techniques. $\mathrm{Sm}-\mathrm{Nd}$ isochron ages for silicate minerals indicate primary crystallization prior to $4.4 \mathrm{Gyr}$ ago. ${ }^{39} \mathrm{Ar}-{ }^{40} \mathrm{Ar}$ ages for the silicates indicate Ar-outgassing between $\sim 3.9-4.1 \mathrm{Gyr}$ ago in a secondary heating event, presumably related to impact cratering. $\mathrm{Rb}-\mathrm{Sr}$ ages of different subsamples have given different results, apparently related to both primary crystallization and secondary reheating. Attempts to date secondary carbonates within ALH84001 have yielded ages as low as $\sim 1.4 \mathrm{Gyr}$ and as high as $\sim 4.0$ Gyr. We prefer a carbonate age of $\sim 3.9 \mathrm{Gyr}$, which would make carbonate formation directly or indirectly related to the cratering event that reset the ${ }^{39} \mathrm{Ar}-{ }^{40} \mathrm{Ar}$ age.

Nd isotopic data plotted along a $4.56 \mathrm{Gyr}$ reference isochron. However, they neither reported an isochron regression nor estimated an uncertainty on the age. Their data were for bulk samples and acid leach/residue pairs, and thus any "isochron" also may be interpreted as an "unmixing" line. This is because phosphate minerals, major contributors to the REE budget, would be dissolved into the "leach" solutions, leaving the residue as a complementary end member. Nyquist et al. (1995) reported both Sm-Nd and Rb-Sr data for ALH84001. They obtained a ${ }^{147} \mathrm{Sm}-{ }^{144} \mathrm{Nd}$ isochron age of $4.50 \pm 0.13 \mathrm{Gyr}$ from a suite of bulk samples and a pyroxene mineral separate. Their isochron also could be interpreted as a mixing line between orthopyroxene and a second component of low Sm-Nd ratio, like phosphate, if that component dominated the REE budget of the rock. However, both phosphate and plagioclase have low $\mathrm{Sm} / \mathrm{Nd}$ ratios, and contribute to the REE budget. Because both are in low abundance, both could be randomly distributed among the different bulk samples analysed, decreasing the likelihood that the isochron is simply a two-component mixing line. Nyquist et al. (1995) also determined initial $\left({ }^{146} \mathrm{Sm} /{ }^{144} \mathrm{Sm}\right)_{\mathrm{I}}=0.0022 \pm 0.0010$ for ALH84001 from variations in ${ }^{142} \mathrm{Nd} /{ }^{144} \mathrm{Nd}$ caused by decay of ${ }^{146} \mathrm{Sm}\left(\mathrm{T}_{1 / 2}=103 \mathrm{Myr}\right)$, initially present in the rock, to ${ }^{142} \mathrm{Nd}$. This result suggests that ALH84001 formed more than one half-life of ${ }^{146} \mathrm{Sm}$ after the angrite meteorite LEW86010, for which $\left({ }^{146} \mathrm{Sm} /{ }^{144} \mathrm{Sm}\right)_{I}$ was $\sim 0.0070$ 
0.0076 (Lugmair and Galer, 1992; Nyquist et al., 1994). The ${ }^{146} \mathrm{Sm} /{ }^{144} \mathrm{Sm}$ ratio requires closure of the Sm-Nd system in ALH84001 no earlier than $\sim 115 \mathrm{Myr}$ after formation of the angrite. Although ${ }^{142} \mathrm{Nd} /{ }^{144} \mathrm{Nd}$ measurements are analytically challenging, the long- and short-lived chronometers can be considered concordant for an age of $\sim 4.4 \mathrm{Gyr}$, the lower limit on the conventional ${ }^{147} \mathrm{Sm}^{-144} \mathrm{Nd}$ age. Thus, the great antiquity of ALH84001 appears to be established, in spite of generally lower ${ }^{39} \mathrm{Ar}-{ }^{40} \mathrm{Ar}$ ages, and a lower Rb-Sr age (Wadhwa and Lugmair, 1996).

The ${ }^{39} \mathrm{Ar}^{-40} \mathrm{Ar}$ ages of ALH84001 are in the range $~ 3.8-4.2$ Gyr (Figure 3). Thus, Ar-outgassing appears to have occurred after the parental rock solidified. Turner et al. (1997) derived an ${ }^{39} \mathrm{Ar}-{ }^{40} \mathrm{Ar}$ age of $3.92 \pm 0.10 \mathrm{Gyr}$, whereas Ilg et al. (1997) reported an older age of $4.07 \pm 0.04$ Gyr. Martian Ar components in ALH84001 are difficult to characterize, and correcting for the uncertainty in trapped Martian ${ }^{40} \mathrm{Ar}$ allows ages in the broader interval 4.10 $\pm 0.20 \mathrm{Gyr}$ (Bogard and Garrison, 1999). The time when ALH84001 was outgassed corresponds to the hypothesized period of the "terminal cataclysm" on the moon and HED parent body (Bogard, 1995). Perhaps Mars also experienced such a cataclysmic bombardment, but this remains a tentative conclusion, based on a single sample.

The Rb-Sr age of 3.84 \pm 0.05 Gyr for ALH84001 (Wadhwa and Lugmair, 1996) is significantly younger than the $\mathrm{Sm}-\mathrm{Nd}$ age and also than the $\mathrm{Rb}-\mathrm{Sr}$ age of Nyquist et al. (1995). Apparently, the secondary reheating event that reset the ${ }^{39} \mathrm{Ar}^{40} \mathrm{Ar}$ age affected different portions of the rock to different degrees. The rock contains crushed zones (Treiman, 1995b) that may have been more severely affected by the impact event than were intact orthopyroxenite areas. Furthermore, secondary carbonate mineralization is preferentially found within these crushed zones. Thus, we concur with the interpretation of Wadhwa and Lugmair (1996) that the young RbSr age of $\sim 3.9$ Gyr $\left({ }^{87} \mathrm{Sr}\right.$ decay constant $\lambda_{87}=1.402 \times 10^{-11} \mathrm{yr}^{-1}$, Minster et al., 1982) represents a time of intense shock and post-shock thermal annealing. This interpretation implies that the $\mathrm{Rb}$-Sr ages of some portions of the rock also were reset by the impact of a large meteoroid on Mars. Both interpretations may apply, as ALH84001 bears evidence of several major meteoroid impacts (cf. Treiman, 1998), not surprising for a rock from the Martian highlands, which have been "gardened" by meteoroid impact to a depth of $\sim 1 \mathrm{~km}$ (Hartmann et al., 2000).

ALH84001 contains $\sim 1$ vol.\% of secondary carbonates. The secondary $\mathrm{Sr}$ or $\mathrm{Nd}$ in these carbonates may have disturbed the isotopic systems. The work of Borg et al. (1999), discussed below, shows that the leaching procedure used by Jagoutz et al. (1994) to determine the Sm-Nd age of ALH84001 would have dissolved both igneous phosphates and secondary carbonates. Also, the isochron of Nyquist et al. (1995), determined by bulk samples plus orthopyroxene, would be subject to variations in the relative proportions of phosphates and carbonates. The REE abundances in the primary phosphates probably are much higher than in the secondary carbonates, however, and it is likely that the presence of carbonates has not significantly affected the $\mathrm{Sm}-\mathrm{Nd}$ isochrons. 
Three attempts to date the carbonates have been reported (Figure 3). Knott et al. (1996) reported an age of $\sim 3.6 \mathrm{Gyr}$ by laser-probe ${ }^{39} \mathrm{Ar}-{ }^{40} \mathrm{Ar}$ dating. Turner et al. (1997), however, interpreted those data as heavily influenced by outgassing from the plagioclase substrate beneath the carbonate grain they analysed. Wadhwa and Lugmair (1996), adopting the model of Treiman (1995b) for formation of the carbonates by replacement of plagioclase, proposed an age of $1.41 \pm 0.10 \mathrm{Gyr}$ for the carbonates from a two-point carbonate-plagioclase "isochron". However, the Sr-isotopic composition of plagioclase is variable, making pairing of carbonate and plagioclase for dating ambiguous. In the third investigation of the carbonate age, Borg et al. (1999) exploited the compositional zoning of the carbonate minerals in ALH84001 to selectively dissolve phases having different parent/daughter ratios for $\mathrm{Rb}-\mathrm{Sr}, \mathrm{U}-\mathrm{Pb}$, and $\mathrm{Sm}-\mathrm{Nd}$ dating. Although REE concentrations in the resultant solutions were too low for $\mathrm{Nd}$ isotopic analysis, the $\mathrm{Rb}-\mathrm{Sr}$ and $\mathrm{U}-\mathrm{Pb}$ isotopic analyses yielded concordant ages of $\sim 3.9-4.0 \mathrm{Gyr}$, close to those originally obtained by laser probe ${ }^{39} \mathrm{Ar}-{ }^{40} \mathrm{Ar}$ dating (Knott et al., 1996). These results, combined with the ${ }^{39} \mathrm{Ar}-{ }^{40} \mathrm{Ar}$ studies of ALH84001 silicates, suggest that plagioclase outgassing and carbonate formation were contemporaneous, and possibly even simultaneous. If so, the lower ${ }^{39} \mathrm{Ar}^{40} \mathrm{Ar}$ age reported for "carbonate" by Knott et al. (1996) may reflect some ${ }^{40} \mathrm{Ar}$ loss from this low-temperature secondary mineral phase.

Differences in interpretation of the radiometric age data for the carbonates may be related to the fact that there are several types, and possibly two or more generations, of carbonates present in ALH84001. Mittlefehldt (1994) identified two generations, "early" (pre-shock) carbonates, and "late" (post-shock) carbonates. Treiman (1995b) suggested the carbonates formed via replacement of plagioclase, a suggestion that strongly influenced the $\mathrm{Rb}-\mathrm{Sr}$ study of Wadhwa and Lugmair (1996), as well as interpretation of the ${ }^{39} \mathrm{Ar}-{ }^{40} \mathrm{Ar}$ study of Knott et al. (1996). Gleason et al. (1997) and Kring et al. (1998) also favored carbonate formation via dissolution-replacement reactions between $\mathrm{CO}_{2}$-charged fluids and maskelynite. They present as evidence carbonates filling small pockets in pyroxene previously occupied by maskelynite, as seen in photomicrographs of a thin section of the meteorite (Gleason et al., 1997; Figure 4). Kring et al. (1998) argue from an electron microprobe study of $\mathrm{K}$ and $\mathrm{Ca}$ in six different complexly zoned carbonate patches in a single thin section that the laser probe ${ }^{39} \mathrm{Ar}-{ }^{40} \mathrm{Ar}$ study of Knott et al. (1996), as reported by Turner et al. (1997), does not give the age of the carbonates. They reached this conclusion because most of the data for which carbonate was identified as the target in the study of Turner et al. (1997) showed the presence of more $\mathrm{K}$ than could be accounted for by carbonates alone in the electron probe study. However, carbonates $\sim 100 \mu \mathrm{m}$ in diameter also are easily visible with a binocular microscope along fractured surfaces of macroscopic pieces of the meteorite. There usually is no visible association with comparatively rare maskelynite, although sometimes such an association does exist. (The proportions of maskelynite and carbonate are subequal at $\sim 1 \%$ ). These latter carbonates are of the globular variety, a photomicrograph of which was shown by McKay et al. (1996). These 
fracture-filling carbonates are described very completely in the paper by Scott et al. (1998), and were the intended objects of the investigation by Borg et al. (1999) of carbonate fragments picked from $\sim 1 \mathrm{~g}$ of the meteorite.

It seems probable that some of the confusion concerning interpretation of the carbonate ages stems from occasionally inappropriate application of observations made on limited samples of the meteorite. Here, we follow most closely the discussion of Scott et al. (1998), who examined nine polished thin sections of the meteorite. Quoting: "Carbonates in ALH84001 occur in three distinct locations: in pyroxene fractures, in crushed zones (also called granular bands; Treiman, 1995b), and as massive grains and globules on pyroxene grain boundaries (e.g., Mittlefehldt, 1994; Treiman, 1995b) .... Carbonates in pyroxene fractures can be divided conveniently into three types according to their shape and nature of the fractures in which they formed: disks, dike-shaped veins, and irregularly shaped grains." These authors (and others) document that all types of carbonates are similarly compositionally zoned. The carbonates nucleated with Ca-rich cores and became richer in $\mathrm{Fe}$ and then $\mathrm{Mg}$ as they grew outward. Last to form were the magnesite rims. It is this zonation that the experiment of Borg et al. (1999) was designed to exploit: Enrichment of $\mathrm{Sr}$ and $\mathrm{Pb}$ over $\mathrm{Rb}$ and $\mathrm{U}$ in the $\mathrm{Ca}$-rich cores, leaving enhanced $\mathrm{Rb} / \mathrm{Sr}$ and $\mathrm{U} / \mathrm{Pb}$ ratios in the last-formed magnesites. Similar zoning profiles in all types of carbonates imply that carbonate formation took place as a single event. Again quoting Scott et al.: "...there is much evidence that carbonates in fractures did not form by replacement of plagioclase glass."

The simplest interpretation of the observations appears to be:

1. Some carbonates formed by replacement reactions with crystalline plagioclase. A probable example is seen in Figure 4d of Gleason et al. (1997). If, as argued by the authors and Kring et al. (1998), replacement was of maskelynite, a prior shock event is required.

2. Not all carbonates formed by replacement reactions (Scott et al., 1998). The majority of carbonates probably formed without need of plagioclase or maskelynite, but if some were present, reactions could occur. $\mathrm{CO}_{2}$-enriched aqueous fluids apparently circulated through the rock, implying the prior existence of a fracture network. Thus, the rock had been brecciated prior to that time, probably by excavation from great depth to a surface or near-surface location. The compositional zoning of the carbonates was established at that time, and dated at $\sim 4.0 \mathrm{Gyr}$ ago by Borg et al. (1999).

3. A second shock fractured some carbonates and formed maskelynite and plagioclase glass, some of which can now be found in fractures. This shock also opened up some pre- existing fractures in which carbonates already had formed (Scott et al., 1998, Figure 3a), and resealed others. This last shock is most likely the ejection event. The other Martian meteorites invariably show shock levels of 15-45 GPa, implying that such shock levels are required for their ejection from the planet. Thus, this second shock happened $\sim 15 \mathrm{Myr}$ ago, the ejection age of ALH84001, as discussed in a later section. 
Treiman (1998) suggested a more complex scenario involving 4 "compositional", 6 to 8 "deformational", and 4 "impact" events. A critical difference to the scenario above is that Treiman's last impact event occurs without major shock metamorphism. Attempts to refine the inferred history of ALH84001, including the radiometric age of the carbonates, are likely to continue, but the concordant $\mathrm{Rb}-\mathrm{Sr}$ and U-Pb ages of Borg et al. (1999) seem presently to be preferred.

The mechanism of carbonate formation has been debated in the context of "impact metasomatism" (Harvey and McSween, 1996) and "playa lake" models. Playa lake models have gained favor, seeming to be more consistent with various types of data (cf., Warren, 1998). Also, in an experimental study, Golden et al. (2000a, 2000b) were able to reproduce the carbonate zonation profiles in ALH84001. They used a multi-step, sequential aqueous precipitation from fluids of changing composition, followed by a final reheating to $470^{\circ} \mathrm{C}$. Whether this process mimics what might happen on Mars, perhaps in a Martian playa lake, has not been addressed in detail. However, one can easily envision a scenario in which Ar-outgassing from ALH84001 accompanied a crater-forming event that left ALH84001 either as part of the crater ejecta blanket, or, in the playa lake model, at the bottom of a crater. Scott et al. (1998) have suggested that ALH84001 may have been located beneath the central region of a large impact crater or basin that formed $\sim 4$ Gyr ago. The playa lake model would definitely be favored over impact metasomatism if $\mathrm{Ar}$ outgassing were earlier than carbonate formation, occuring at most $4.1 \mathrm{Gyr}$ ago. The carbonate age data would then be consistent with precipitation from a crater lake filled slightly later by surface runoff into the crater. Alternatively, formation of a crater lake might be triggered by formation of the crater itself, filled by melted groundwater released by the heat of the impact. Newsom et al. (1996) have argued that formation of large ( $>65 \mathrm{~km}$ diameter) impact craters on Mars may have been accompanied by the creation of ice-covered impact crater lakes, which would not freeze totally over a lifetime of $\sim 10^{4}$ years. Supply of water to them from deep aquifirs might provide a connection to possible life residing in the aquifirs (Boston et al., 1992). Thus, although the suggestion by McKay et al. (1996) that certain worm-like morphological features in ALH84001 might be relics of Martian life has proven controversial, that interpretation is consistent with the apparent age of the carbonates, the time of formation of equivalent lifeforms on earth, and possible access to potential subsurface habitats via crater formation. The crater lake scenario remains speculative, but is consistent with suggested modes of carbonate formation, and is made more plausible by the apparent near coincidence of the outgassing and carbonate formation ages. The apparent presence of liquid water at later times, perhaps even up to the present day (Malin and Edgett, 2000), appears to be permissive of later carbonate formation also. Currently, however, there appears to be little rationale to consider alternate scenarios.

Although ALH84001 is a sample of the Noachian crust, it should not be considered a "typical" Martian crustal rock. It is an orthopyroxenite cumulate with much higher $\mathrm{MgO}$ and $\mathrm{FeO}$, and lower $\mathrm{Al}_{2} \mathrm{O}_{3}, \mathrm{SiO}_{2}$, and $\mathrm{K}_{2} \mathrm{O}$ than typical Martian 
crustal rocks such as the Pathfinder "sulfur free rock" (Rieder et al., 1997; Bell et al., 2000). Although rocks at the Pathfinder site are thought to be derivative from the southern Martian highlands, the $\mathrm{Al}_{2} \mathrm{O}_{3}$ content of the "sulfur free rock" is much lower than that of lunar highland soils and even lower than in lunar mare soils. On average, the Martian crust appears to be rather $\mathrm{Al}_{2} \mathrm{O}_{3}$-poor. McSween and Keil (2000) conclude that if the global Martian dust is representative of the Martian upper crustal composition, the planet's surface geology is dominated by contributions from evaporitic salts and a basaltic protolith chemically similar to basaltic shergottites. Thus, fractionated $\mathrm{MgO}$ - and $\mathrm{FeO}-$ rich magmas may have been common within the crust, and orthopyroxenite ALH84001 may have formed as a mafic cumulate in a layered igneous province. The mode and timing of its formation may have been analogous to those of rocks of the lunar "Mg-suite", except that the composition of the surrounding crust was basaltic rather than anorthositic.

Finally, viewed from the context of the lunar samples, it seems fortuitous that even one out of 16 dated Martian rocks would have preserved such an old age. Only a few lunar crustal rocks have been reliably dated to have ages in the range of 4.3-4.5 Gyr. Furthermore, the dated lunar ferroan anorthosites were small clasts extracted from lunar highland breccias, in which they often were surrounded by impact melt glass. The rarity of unadulterated "original" crustal material among the lunar highlands rocks poses some questions relative to ALH84001 and the Martian crust: Did Mars and Moon both experience the same heavy meteor bombardment early in their history? Did Mars experience a "terminal cataclysm" of bombardment? Was ALH84001 excavated from a considerable depth where it was shielded from bombardment? If 4.5 Gyr-old crustal rocks are fairly common on Mars, but not on the Moon, it may imply that the moon had a much heavier terminal bombardment that physically destroyed its crust. ALH84001 has given us a few clues, but answers to these questions await combination of spacecraft orbital imaging and absolute dating of samples returned from heavily cratered areas on Mars.

\subsection{The Nakhlites And Chassigny: Amazonian or Hesperian CuMulates?}

So far, we have no Martian meteorites that are clearly Hesperian in age; i.e., 3.51.8 Gyr old, according to the Hartmann-Tanaka (HT) cratering model, or even older according to Hartmann and Neukum (2001). The $\sim 1.3$ Gyr radiometric ages of four cumulate rocks, three clinopyroxenite nakhlites (Nakhla, Lafayette, and Governador Valadares), and the dunite Chassigny (Figure 2) are Early Amazonian in the HT model, but close to the lower age limit of the Hesperian. However, they are squarely in the Middle Amazonian in the Neukum-Wise (NW) model. Close agreement of the ages of these four meteorites by four dating techniques, $\mathrm{Rb}-\mathrm{Sr}, \mathrm{Sm}-\mathrm{Nd}$, ${ }^{39} \mathrm{Ar}-{ }^{40} \mathrm{Ar}$, and $\mathrm{U}-\mathrm{Pb}$, apparently unambiguously define their crystallization ages at $\sim 1.3$ Gyr (Figure 4). Type localities for the Early and Middle Amazonian are Amazonis Planitia (EA) and Acidalia Planitia (MA), respectively (Tanaka, 1986). 


\section{Ages of Nakhlites \& Chassigny}

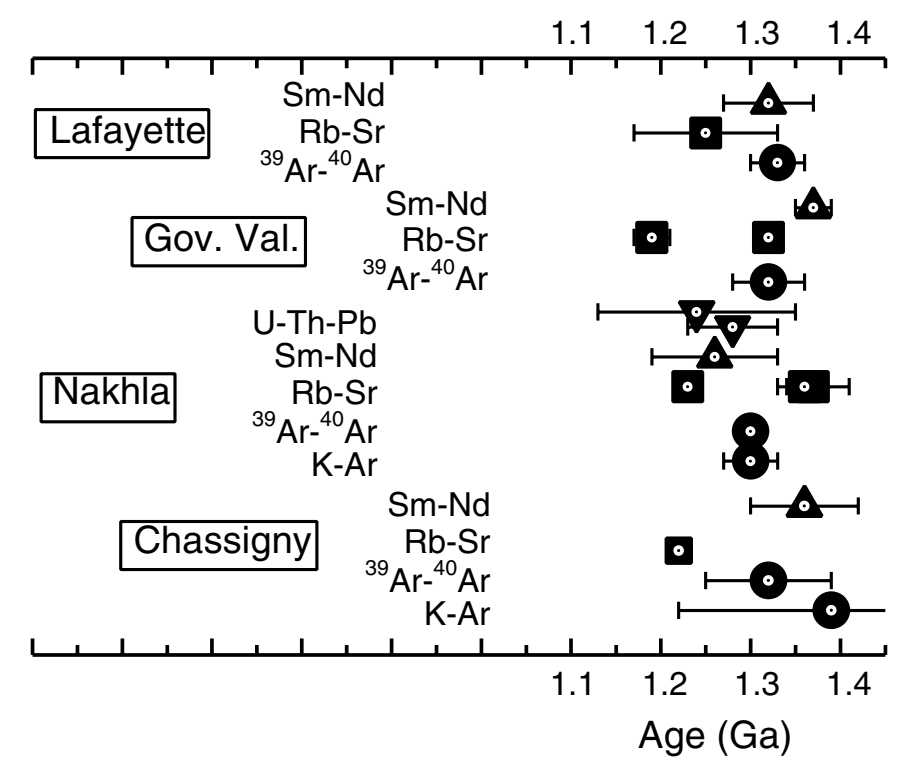

Figure 4. Radiometric ages of the Nakhlites and Chassigny. Nearly all the ages are compatible with an average age of $\sim 1.3 \mathrm{Gyr}$.

Although the radiometric ages of the nakhlites are in general well-defined, they do show some isotopic disturbances, first evident in the Sr-isotopic heterogeneity noted by Papanastassiou and Wasserburg (1974). Some of the disturbance may be attributed to iddingsite, an apparent Martian weathering product formed during alteration by water. Some of the isotopic heterogeneity may perhaps be magmatic in origin. Attempts to date the formation time of iddingsite in the Lafayette nakhlite by the $\mathrm{K}-\mathrm{Ar}$ and $\mathrm{Rb}-\mathrm{Sr}$ techniques have yielded apparent ages of $600-700 \mathrm{Myr}$ (Swindle et al., 1999; Shih et al., 1998), suggesting liquid water activity on Mars $\sim 650$ Myr ago. Malin and Edgett (2000) have cited a number of lines of evidence, such as the observations of gullies within the walls of a small number of impact craters, as indicating groundwater seepage and surface run-off on even younger Martian landforms. Examples are shown in this book (Hartmann, 2001).

\subsection{The Shergottites: Late AmaZonian Volcanism}

The preferred radiometric ages of basaltic and lherzolitic shergottites lie in the range $\sim 165-475$ Myr. Individual ages from the literature and unpublished data from the JSC lab are given in Table III and are shown with error limits in Figure 5. Confusion about the ages of the shergottites is slowly being dispelled. The initial apparent age discordance of the shergottites has been shown to arise from three sources: a) The presence of trapped ${ }^{40} \mathrm{Ar}$ from the Martian atmosphere and mantle, and possibly excess, inherited, radiogenic ${ }^{40} \mathrm{Ar}$ as well, in sufficient quan- 


\section{Age of Shergottites}

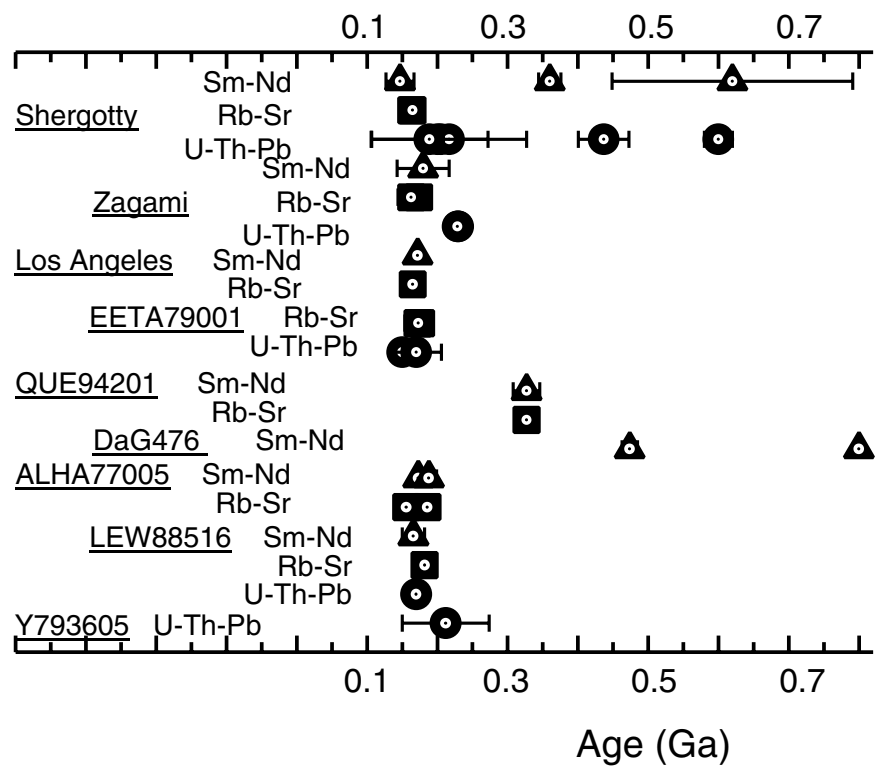

Figure 5. Radiometric ages of the shergottites. The Shergotty ages $>0.3 \mathrm{Gyr}$ seem to be in error due to unexplained analytical effects. Concordant $\mathrm{Rb}-\mathrm{Sr}$ and $\mathrm{Sm}-\mathrm{Nd}$ ages of $\sim 327 \mathrm{Myr}$ indicate that age is the true crystallization of QUE94201. The ubiquitous presence of terrestrial contamination has prevented determination of a $\mathrm{Rb}-\mathrm{Sr}$ age for $\mathrm{DaG} 476$. The ubiquity of such contamination causes us to favor the $475 \pm 11 \mathrm{Myr}$ Sm-Nd age of Borg et al. (2000) to the older $\sim 800 \mathrm{Myr}$ age reported by Jagoutz et al. (1999) and Jagoutz and Jotter (1999) for this meteorite. See Table II for references.

tities to significantly affect measured ${ }^{39} \mathrm{Ar}-{ }^{40} \mathrm{Ar}$ ages. b) Analytical difficulties accompanying isotopic analyses of young samples with low abundances of the trace elements being analysed. c) The apparent presence of isotopic heterogeneity probably preserved in the basalts in the cores of pyroxene and olivine phenocrysts. These difficulties are being worked out, and preferred ages can be given with a degree of confidence (Table III).

It is also worth noting that a major contributor to initial confusion about the ages of the shergottites, and indeed all the SNC meteorites, was simply an early reluctance of meteoriticists to accept radiometric ages significantly less than $\sim 4.5 \mathrm{Gyr}$ as giving the time of igneous crystallization of any meteorite. The first radiometric age for a meteorite now considered to be of Martian origin was the K-Ar age of $580 \pm 50 \mathrm{Myr}$ (recalculated with the decay parameters by Steiger and Jäger, 1977) determined for Shergotty by Geiss and Hess (1958) in an early study of the K-Ar ages of stony meteorites. Geiss and Hess (1958) considered their age to be "too young". They excluded the possibilities of K contamination or heterogeneity in the K content of the meteorite. Not knowing of Shergotty's Martian origin and, hence, assuming that Ar extracted from the meteorite could only consist of the 
radiogenic, spallogenic, and (terrestrial) atmospheric components, they considered Ar loss as being unlikely to explain its young age. A loss of $\sim 95 \%$ of the Ar would be required, and they concluded that diffusive loss of that magnitude would be unlikely either via solar heating at the earth's orbit or beyond, or via frictional heating during passage through earth's atmosphere. We now know that correction for the "atmospheric" component using ${ }^{40} \mathrm{Ar} /{ }^{36} \mathrm{Ar} \sim 2000$ for the Martian atmosphere, instead of 296 for the terrestrial atmosphere, gives an even younger age, more in agreement with currently accepted values for the Martian meteorites. Of course, the possible presence of a second atmospheric component, and the possibility that these young rocks might contain a mantle Ar component as well, introduces ambiguity in correcting for non-radiogenic ${ }^{40} \mathrm{Ar}$. Later work showed that K-Ar ages $<1$ Gyr were relatively common among shocked chondritic meteorites and are produced by impact heating on meteorite parent bodies.

The question of the age of Shergotty was revisited by Bogard et al. (1979), who redetermined the $\mathrm{K}-\mathrm{Ar}$ age using the ${ }^{39} \mathrm{Ar}^{40} \mathrm{Ar}$ technique, and also by Nyquist $e t$ al. (1979b), who determined the $\mathrm{Rb}-\mathrm{Sr}$ age as well. The ${ }^{39} \mathrm{Ar}-{ }^{40} \mathrm{Ar}$ ages of stepped extractions of Ar from a whole rock were variable, but similar to the value of Geiss and Hess (1958). The ${ }^{39} \mathrm{Ar}^{40} \mathrm{Ar}$ ages of stepped extractions from a plagioclase separate were approximately constant and gave a good age plateau at $254 \pm 10 \mathrm{Myr}$. The Rb-Sr age was younger still at 165 \pm 11 Myr. Nyquist et al. (1979b) interpreted the $\sim 165 \mathrm{Myr} \mathrm{Rb}$-Sr age of Shergotty as due to metamorphic resetting because it was the lower of the $\mathrm{Rb}$-Sr and ${ }^{39} \mathrm{Ar}-{ }^{40} \mathrm{Ar}$ ages. Subsequent work showed that not only was the $\mathrm{Rb}$-Sr age younger than the ${ }^{39} \mathrm{Ar}-{ }^{40} \mathrm{Ar}$ age of $254 \pm 10 \mathrm{Myr}$, but also younger than the still older Sm-Nd and U-Pb ages of Shih et al. (1982), Jagoutz and Wänke (1986), and Chen and Wasserburg (1986) (Table III; Figure 5). These latter measurements mostly have not been repeated, but it now seems likely that they were influenced by sample contamination, or other sources of analytical errors.

A recent in situ isotopic analysis by ion probe of $\mathrm{U}-\mathrm{Th}-\mathrm{Pb}$ in phosphates in Shergotty (Sano et al., 2000) yields the time of closure of the U-Pb system in Shergotty phosphates as $204 \pm 68 \mathrm{Myr}$ ago. Whether this result excludes those Sm$\mathrm{Nd}$ and U-Pb "ages" in excess of 300 Myr in Figure 5 as real crystallization ages depends on the actual mode of petrogenesis of these rocks. Jagoutz and Wänke (1986) preferred the older Sm-Nd age of $360 \pm 16$ Myr obtained from a pyroxeneleachate isochron to the younger Sm-Nd age of $147 \pm 20 \mathrm{Myr}$ they obtained from an isochron including the whole rock data. However, the lower value of $\sim 147 \mathrm{Myr}$ normally would be favored by the isotopic systematics, since data for the bulk ("whole rock") sample must lie on the isochron for closed-system evolution of the Sm-Nd system. Jagoutz and Wänke (1986) argued for an open Sm-Nd system, and that the phosphates crystallized from a metasomatic contaminant infiltrating a pyroxene cumulate. This possibility continues to be allowed by the results of Sano et al. (2000). Thus, the interpretation of Jagoutz and Wänke (1986) probably cannot be totally excluded, but it is nevertheless weakened by several observations. First, it requires $\mathrm{Sr}$ in plagioclase, as well as $\mathrm{Nd}$ in phosphates, to be derived 
from the metasomatic contaminant. Second, the Sm-Nd data for Shergotty also can be explained by recent terrestrial contamination, which may have been a greater problem than previously recognized. Third, Bogard and Garrison (1999) decomposed the Ar released from an irradiated sample of Shergotty into a radiogenic component that would be produced in $165 \mathrm{Myr}$ of decay, and a trapped component with an ${ }^{40} \mathrm{Ar} /{ }^{36} \mathrm{Ar}$ ratio of 1780 . This ${ }^{40} \mathrm{Ar} /{ }^{36} \mathrm{Ar}$ ratio is within the range of values believed representative of the Martian atmosphere, supporting the validity of this approach. Because most of the $\mathrm{K}$ and radiogenic ${ }^{40} \mathrm{Ar}^{*}$ is contained in plagioclase, this result would require that most of the $\mathrm{K}$, as well as $\mathrm{Nd}$ and $\mathrm{Sr}$, be attributed to the hypothesized metasomatic fluid. These more recent observations substantially support the earlier arguments of Jones (1986) against metamorphic resetting of the $\mathrm{Rb}$-Sr ages of Shergotty and other shergottites by either thermal or hydrothermal events. Finally, a Sm-Nd age of $163 \pm 7$ Myr was found for Zagami, a "twin" of Shergotty (Nyquist et al., 1995), concordant with three determinations of the $\mathrm{Rb}-\mathrm{Sr}$ age averaging $177 \pm 3$ Myr. These arguments suggest that an age of crystallization as old as $\sim 360 \mathrm{Myr}$ for Shergotty is unlikely. Our preferred age of $165 \pm 4 \mathrm{Myr}$ is the weighted average of the two Rb-Sr ages (Nyquist et al., 1979b; Jagoutz and Wänke, 1986) converted to a ${ }^{87} \mathrm{Sr}$ decay constant $\lambda_{87}=0.01402 \mathrm{Gyr}^{-1}$, as used throughout this paper (Minster et al., 1982).

That the young radiometric ages of the SNCs are indeed crystallization ages seems incontrovertible in light of the recent data summarized in Tables II and III. Three other basaltic shergottites, Zagami, EET79001, and Los Angeles have similar preferred ages as Shergotty; i.e., $177 \pm 3 \mathrm{Myr}, 173 \pm 3 \mathrm{Myr}$, and $170 \pm 7 \mathrm{Myr}$, respectively. For Zagami, the value is based on three $\mathrm{Rb}-\mathrm{Sr}$ ages and one $\mathrm{Sm}-\mathrm{Nd}$ age (Table III). For EET79001, the preferred age is based on three $\mathrm{Rb}-\mathrm{Sr}$ ages, one $\mathrm{Sm}-\mathrm{Nd}$ age, and two U-Th-Pb ages. In this case the weighted mean is greatly influenced by a precise $\mathrm{Rb}-\mathrm{Sr}$ age of $173 \pm 3 \mathrm{Myr}$ recently determined in the JSC lab (Nyquist et al., 2001). For Los Angeles, the age is the weighted average of $\mathrm{Rb}-\mathrm{Sr}$ and $\mathrm{Sm}-\mathrm{Nd}$ ages. Although the preferred age for Shergotty appears to be slightly younger, its resolution from the other ages is problematic. The calculated uncertainty of $\pm 4 \mathrm{Myr}$ for the Shergotty age may be unrealistically low in light of apparent $\mathrm{cm}$-scale isotopic heterogeneity in Zagami (Nyquist et al., 1995).

Two of the basaltic shergottites, QUE94201 and DaG 476, have older crystallization ages. Concordant Rb-Sr and Sm-Nd ages of $327 \pm 12$ and $327 \pm 19 \mathrm{Myr}$ were obtained for QUE94201 by Borg et al. (1997). QUE94201 contained easilyleachable components which may have formed as Martian weathering products. The presence of these phases and also of impact-produced glass veining throughout the rock led to significant complications of the isotopic systematics, but, nevertheless, the age appears to be robustly determined.

The age of DaG476, another basaltic shergottite with compositional similarities to QUE94201, is currently debated. Jagoutz et al. (1999), and Jagoutz and Jotter (2000) have presented Sm-Nd data leading to an apparent age of $\sim 800 \mathrm{Myr}$. Borg et al. (2000) found instead an age of $474 \pm 11 \mathrm{Myr}$. This shergottite is heavily 
weathered, making the $\mathrm{Rb}-\mathrm{Sr}$ data useless for age determination. Terrestrial contamination accompanies the weathering throughout the meteorite and is evident in elevated $\mathrm{K}$ and LREE abundances in some mineral phases (Crozaz and Wadhwa, 1999). Because the effect of terrestrial contamination would be to displace the apparent age to higher values, we favor the lower value of $\sim 474$ Myr as most likely to be the true crystallization age.

Concordant $\mathrm{Rb}-\mathrm{Sr}$ and $\mathrm{Sm}-\mathrm{Nd}$ ages have been determined for two of the lherzolitic shergottites, ALH77005, and LEW88516. Our preferred ages for these two meteorites are $178 \pm 6 \mathrm{Myr}$ and $179 \pm 6 \mathrm{Myr}$, respectively (Table III). An U-Pb age of $\sim 170 \mathrm{Myr}$ for LEW88516 (Chen and Wasserburg, 1993) is also concordant with these values, as is an U-Pb age of $212 \pm 62 \mathrm{Myr}$ for the third lherzolitic shergottite, Yamato 793605 (Misawa et al., 1997). These crystallization ages are the same, within uncertainties of a few percent, as the crystallization ages of several of the basaltic shergottites. Historically, these shergottites have been referred to as having crystallization ages of $\sim 180 \mathrm{Myr}$ as suggested by Jones (1986), based on the $178 \pm 3 \mathrm{Myr} \mathrm{Rb}-\mathrm{Sr}$ age reported for Zagami by Shih et al. (1982).

The interpretation of the radiometric data for shergottites has been controversial in part because of the complexities that often exist both within and between radiometric systems. One of the most puzzling problems has been the observation that the apparent ${ }^{39} \mathrm{Ar}^{40} \mathrm{Ar}$ ages of the shergottites are systematically older than the $\mathrm{Rb}$ $\mathrm{Sr}$ ages, as we have already mentioned for Shergotty. Although ${ }^{39} \mathrm{Ar}-{ }^{40} \mathrm{Ar}$ ages in terrestrial basalts can sometimes be "too old" because of inherited radiogenic ${ }^{40} \mathrm{Ar}$, such situations are rare among meteorites. Bogard and Johnson (1983) first found that melt glass in the EET79001 shergottite contained trapped Martian atmospheric gases, including substantial amounts of ${ }^{40} \mathrm{Ar}$, which had been shock-implanted by impacts on the Martian surface. Martian atmospheric gases have also been found in Zagami, ALH77005, and Y793605. In addition, an elementally fractionated component of the Martian atmosphere has been measured in some samples of the nakhlites and ALH84001 (see references in Bogard and Garrison, 1998). The ${ }^{40} \mathrm{Ar} /{ }^{36} \mathrm{Ar}$ ratio of the Martian atmosphere has a relatively high value of $\sim 1800$ (Bogard and Garrison, 1999), which makes it difficult to correct for atmospheric ${ }^{40} \mathrm{Ar}$ using ${ }^{36} \mathrm{Ar}$. Further, it is now recognized that some Martian meteorites contain a trapped volatile component from the Martian interior, which appreciably differs in elemental and isotopic composition from the atmospheric component (Ott, 1988; Bogard and Garrison, 1998; Marti and Matthew, 2000). The ${ }^{40} \mathrm{Ar} /{ }^{36} \mathrm{Ar}$ ratio of this interior component is not known and is probably variable. In many phases of Martian meteorites the Martian atmospheric and interior volatile components occur as mixtures in variable proportions.

Because of the presence of multiple Ar components, shergottites do not generally give reliable ${ }^{39} \mathrm{Ar}-{ }^{40} \mathrm{Ar}$ ages (Bogard and Garrison, 1999), as can be seen from the ${ }^{39} \mathrm{Ar}-{ }^{40} \mathrm{Ar}$ ages given for them in Table III. Most of the listed ${ }^{39} \mathrm{Ar}-{ }^{40} \mathrm{Ar}$ ages are from the compilation of Bogard and Garrison (1999), and are "total ${ }^{40} \mathrm{Ar}$ ages" for stepped ${ }^{39} \mathrm{Ar}-{ }^{40} \mathrm{Ar}$ analyses. Those ${ }^{39} \mathrm{Ar}^{40} \mathrm{Ar}$ ages that are closest to the preferred 
crystallization ages of the samples are for plagioclase separates of basaltic shergottites with relatively high modal abundance of plagioclase, and thus relatively high K-contents. Relatively good ${ }^{39} \mathrm{Ar}^{-40} \mathrm{Ar}$ plateau ages of $\sim 254 \mathrm{Myr}$ and $\sim 242 \mathrm{Myr}$ were determined for Shergotty and Zagami feldspar. Also, as already mentioned, it was possible to decompose the $\sim 387 \mathrm{Myr}$ total ${ }^{40} \mathrm{Ar}$ age for a bulk sample of Shergotty into trapped and radiogenic ${ }^{40} \mathrm{Ar}$ components. Data for Zagami feldspar are consistent with a similar decomposition of Ar components for a crystallization age of 180 Myr. However, Bogard and Garrison (1999) were unable to reliably determine the amount of radiogenic ${ }^{40} \mathrm{Ar}$ for other shergottite samples because of the multiplicity of Ar components that might have been present in the analyses. Terribilini et al. (1998) determined a conventional ${ }^{40} \mathrm{~K}-{ }^{40} \mathrm{Ar}$ age of $196 \pm 40 \mathrm{Myr}$ from an isochron plot of ${ }^{40} \mathrm{Ar} /{ }^{\beta 6} \mathrm{Ar}$ versus $\mathrm{K} /{ }^{36} \mathrm{Ar}$ in a bulk sample and separated minerals of Shergotty. The corresponding ratio for trapped ${ }^{40} \mathrm{Ar} /{ }^{36} \mathrm{Ar}$ was found to be $\sim 1100$, however, a value significantly lower than ${ }^{40} \mathrm{Ar} /{ }^{36} \mathrm{Ar} \sim 1800$ in the Martian atmosphere, showing that the shergottites contain both Martian atmospheric $\mathrm{Ar}$ and a mantle $\mathrm{Ar}$ component of significantly lower ${ }^{40} \mathrm{Ar} /{ }^{36} \mathrm{Ar}$ ratio. These two components mix in variable proportions in Martian meteorites, making it necessary to independently determine the ${ }^{40} \mathrm{Ar} /{ }^{36} \mathrm{Ar}$ ratio for each sample.

Subtle isotopic inconsistencies are present in the other isotopic systems as well. Some of these are manifest in the U-Pb ages summarized in Table III. Blichert-Toft et al. (1999) note also that Lu-Hf data for bulk shergottites do not show isochron relationships. $\mathrm{Rb}-\mathrm{Sr}$ isochrons of different samples of the shergottites can give identical ages for different initial ${ }^{87} \mathrm{Sr} /{ }^{86} \mathrm{Sr}$ ratios (e.g., Nyquist et al., 1995). Some isotopic inconsistencies for nakhlites probably are due to the presence of Martian weathering products. The differences in initial ${ }^{87} \mathrm{Sr} /{ }^{86} \mathrm{Sr}$ ratios among subsamples of shergottites and nakhlites require unusual petrogenetic processes.

As already mentioned, the $\mathrm{Rb}-\mathrm{Sr}$ ages were originally interpreted as dating the time of shock metamorphism accompanying their ejection from Mars. An attraction of that explanation was that it accounted for the simultaneity of ages near 180 Myr. Nyquist et al. (1979b) argued that subsolidus isotopic equilibration might be achieved by heating at low temperatures $\left(\sim 300-400^{\circ} \mathrm{C}\right)$ for long times $\left(\sim 10^{4} \mathrm{yr}\right)$ while allowing elemental zoning to be preserved. Jones (1986) criticized that interpretation on the grounds that preservation of elemental zoning patterns in major mineral phases of the shergottites, in spite of shock-induced transformation of plagioclase to maskelynite, precluded identification of the $\mathrm{Rb}-\mathrm{Sr}$ ages with the time of shock metamorphism.

Because of the discordant ages obtained for Shergotty and other shergottites by the various methods, Shih et al. (1982) sought an approach that would "see through" secondary events, if such were the explanation of the young, $\sim 180 \mathrm{Myr}$ ages. They noted that the whole rock Sm-Nd data for the basaltic shergottites, Shergotty and Zagami, combined with that of the lherzolitic shergottite, ALH77005, defined an apparent "isochron" of slope corresponding to an age of $\sim 1.34 \mathrm{Gyr}$, in remarkable agreement with the ages of the nakhlites. This coincidence was 


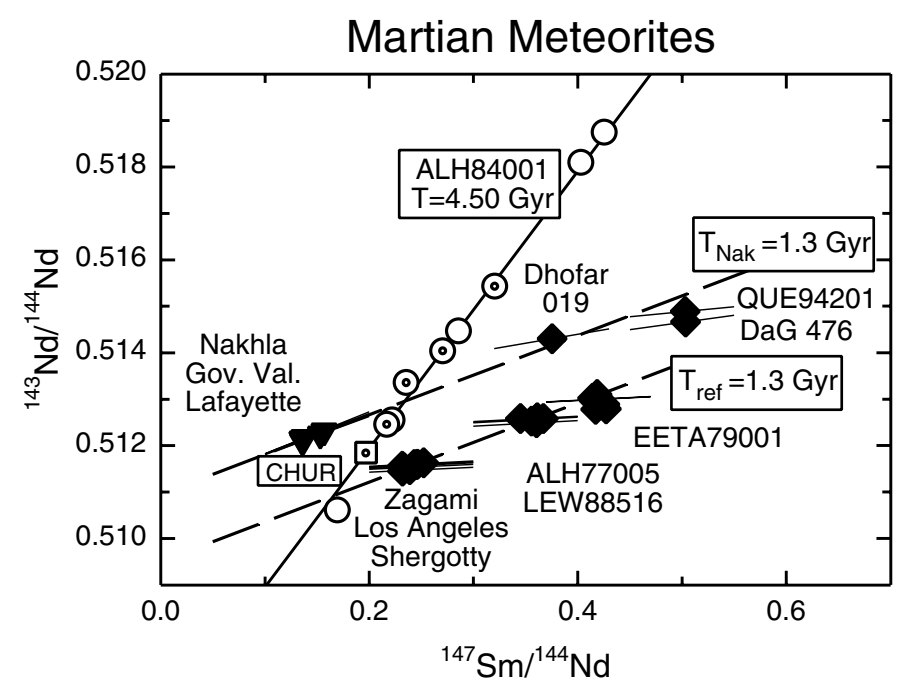

Figure 6. Whole rock Sm-Nd data for Martian meteorites. A $4.50 \mathrm{Gyr}$ reference isochron is shown for bulk samples (dotted circles) and mineral separates (open circles) for ALH84001 orthopyroxenite. Dhofar019: preliminary data, Borg et al. (2001a). DaG476: constructed from the mineral isochron (Borg et al., 2000) and the bulk ${ }^{147} \mathrm{Sm} /{ }^{144} \mathrm{Nd}$ ratio (Jagoutz et al., 1999). The other data are from the literature. A reference 1.3 Gyr isochron $\left(T_{\text {ref }}\right)$ has been drawn through the data for Shergotty, Zagami, and Los Angeles. For reasons that are unclear, the data of the shergottites Dhofar019, QUE94201, and DaG476 appear to lie along $T_{\text {nak }}$, a nakhlite isochron for the average age of the nakhlites Nakhla, Governador Valadares, and Lafayette. The linear alignment along $T_{\text {ref }}$ from the traditional shergottites to EETA79001 has been interpreted as a mixing line between a mantle component to the right of EETA79001 and a "crustal" component to the left of the intersection of this line with the $\sim 4.5$ Gyr isochron. The isotopic data for a Chondritic Uniform Reservoir (CHUR) fall on this isochron (squares). Short lines through the individual data points show the slopes of mineral isochrons determined for these rocks. Rocks satisfying a simple two-stage isotopic evolution history would be derived from Martian mantle source regions having ${ }^{147} \mathrm{Sm} /{ }^{144} \mathrm{Nd}$ ratios determined by the intersection of the mineral isochrons with the primary $\sim 4.5$ Gyr mantle differentiation isochron. Such an intersection would occur at ${ }^{147} \mathrm{Sm} /{ }^{144} \mathrm{Nd} \sim 0.3$ for QUE94201, DaG476, and Dhofar 019 . QUE94201, DaG476, and the nakhlites also have measured excesses of ${ }^{142} \mathrm{Nd}$ from decay of $103 \mathrm{Myr}$ ${ }^{146} \mathrm{Sm}$ (Harper et al., 1995; Borg et al., 1997; Jagoutz and Jotter, 2000), showing that Martian differentiation occurred very early. The likely addition of a crustal component to the parental magmas of the younger, $\sim 175 \mathrm{Myr}$ old shergottites would have displaced the apparent mantle ${ }^{147} \mathrm{Sm} /{ }^{144} \mathrm{Nd}$ ratios to the lower left along the primary mantle isochron.

reinforced by later data for basaltic shergottite EET79001. It seemed to suggest that the shergottites and the nakhlites might be related, if only indirectly, via mantle processes. It also suggested that the $\sim 1.3 \mathrm{Gyr}$ age might have significance for the shergottites. However, later interpretations have favored the view that this "isochron" is a mixing line, representing mixing among "crustal" and "mantle" end-members as suggested by Jones (1989) and Longhi (1991).

Figure 6 shows the currently available whole rock Sm-Nd data for Martian meteorites. Whole rock analyses and mineral separates for ALH84001 define an 
$\sim 4.5$ Gyr reference isochron, used here as a reference isochron giving the approximate age of the planet. The "traditional" basaltic shergottites (Shergotty, Zagami, and Los Angeles), plus the lherzolitic shergottites (ALH77005 and LEW88516) and basaltic shergottite EET79001 plot along an $\sim 1.3$ Gyr reference isochron similar to the one originally defined for Shergotty, Zagami, and ALH77005 by Shih et al. (1982). The line in the figure is constrained to pass through the data for the traditional basaltic shergottites. According to the isotopic mixing models of Jones (1989) and Longhi (1991), the linear alignment of data is due to mixing of more radiogenic $\mathrm{Nd}$ (higher ${ }^{147} \mathrm{Sm} /{ }^{144} \mathrm{Nd}$ and ${ }^{143} \mathrm{Nd} /{ }^{144} \mathrm{Nd}$ ratios) from the Martian mantle with less radiogenic $\mathrm{Nd}$ (lower ${ }^{147} \mathrm{Sm} /{ }^{144} \mathrm{Nd}$ and ${ }^{143} \mathrm{Nd} /{ }^{144} \mathrm{Nd}$ ratios) from the Martian crust. End member compositions are to be found along the line to the right or left of the data array. This interpretation attributes no time significance to the linear data array, and suggests that the correspondence of the slope of the line to an apparent $\mathrm{Sm}-\mathrm{Nd}$ age of $\sim 1.3 \mathrm{Gyr}$ is a coincidence. This approach has much to recommend it. Norman (1999) found self-consistent results for the $\mathrm{Nd}$ isotopic compositions and REE abundances in Shergotty as a mixture between a LREE-depleted mantle-derived magma similar in composition to EET79001A and a LREE-enriched "crustal" component with $>10 \mathrm{ppm} \mathrm{Nd}$. The success of such models depends in large part on identification of at least one of the end member components. A number of meteorites have been suggested as representative of mantle-derived Martian magmas, including the nakhlites (Jones, 1989; Longhi, 1991), QUE94201 (Borg et al., 1997), and EET79001 (Norman, 1999).

Recent data for newly found Martian meteorites have reopened the issue of whether Sm-Nd whole rock "isochrons" may have time significance, however. Jagoutz and Jotter (2000) note that leachates ( phosphates) from Nakhla, DaG476, and QUE94201 lie along a line of slope corresponding to an isochron age of $1.2 \mathrm{Gyr}$, and that these samples all have significant excess ${ }^{142} \mathrm{Nd}$ anomalies, showing that they all were derived from an early-formed mantle source with significant depletion in LREE relative to HREE (H for Heavy; $c f$. Harper et al., 1995). Figure 6 shows that whole rock data for the nakhlites (Shih et al., 1998, 1999), QUE94201 (Borg et al., 1997), and newly found Dhofar019 (Borg et al., 2001a) all plot close to the extension of the $1.3 \mathrm{Gyr}$ nakhlite isochron. Because whole rock data for DaG476 are unreliable due to terrestrial contamination, we show a value calculated to lie on the mineral isochron of Borg et al. (2000) for the ${ }^{147} \mathrm{Sm} /{ }^{144} \mathrm{Nd}$ ratio measured by Jagoutz et al. (1999). If the $\sim 1.3 \mathrm{Gyr}$ alignments have any time significance, it may be due to "mantle" end members generated by successive episodes of partial melting and magma extraction over an extended interval from before $\sim 1.3 \mathrm{Gyr}$ ago until the crystallization ages of the basalts. Melt extraction on a massive scale may account for the large depletion of LREE abundances in QUE94201 and DaG476, and may have left surface evidence for large expanses of volcanic flows $\sim 1.3 \mathrm{Gyr}$ ago. Models for the $\mathrm{Nd}$ and $\mathrm{Sr}$ isotopic evolution of QUE94201 (Borg et al., 1997), however, require successive melt extractions from the source to be restricted to times near the basalt crystallization age. 
In contrast to the Sm-Nd data, the whole rock $\mathrm{Rb}$-Sr age for most Martian meteorites is $\sim 4.5 \mathrm{Gyr}$ (Shih et al., 1982). Thus, the $\mathrm{Rb}-\mathrm{Sr}$ data require planet-wide differentiation at $\sim 4.5 \mathrm{Gyr}$, accompanied by establishment of mantle reservoirs that remained essentially closed systems to $\mathrm{Rb} / \mathrm{Sr}$ fractionation thereafter. That major fractionation in Sm-Nd could occur $<\sim 1.3 \mathrm{Gyr}$ ago without some additional fractionation of $\mathrm{Rb} / \mathrm{Sr}$ is a strong constraint on isotopic models for crust/mantle differentiation. The models of Jones (1989) and Longhi (1991) for the petrogenesis of SNC meteorites invoked crustal assimilation following partial melting of the Martian mantle for nakhlite genesis at $1.3 \mathrm{Gyr}$ ago and shergottite genesis at $180 \mathrm{Myr}$ ago. Borg et al. (1997) presented a related multi-stage model of mantle melting and crustal assimilation for petrogenesis of QUE94201 at $330 \mathrm{Myr}$ ago.

\section{Ejection Ages and Events}

Assuming a meteorite is ejected as a small object from the Martian surface and comes directly to Earth without secondary breakup in space, its "ejection age", i.e. the time since its ejection, equals the sum of its cosmic ray exposure (CRE) age and its terrestrial age (Eugster et al., 1997b). Table IV gives all presently available CRE and terrestrial ages of Martian meteorites, and its notes explain how these ages were calculated. The CRE ages based on the stable noble gas isotopes ${ }^{3} \mathrm{He},{ }^{21} \mathrm{Ne}$, and ${ }^{38} \mathrm{Ar}$ and appropriate production rates, $T_{\mathrm{s}}$, may be subject to several sources of systematic bias, such as diffusive loss of spallogenic noble gases, which is possibly related to particular orbital parameters, errors in correction of production rates for variations in chemical composition, variations in shielding from cosmic ray particles, and contributions of solar particles to ${ }^{21} \mathrm{Ne}$ production. However, the ${ }^{81} \mathrm{Kr}-\mathrm{Kr}$ ages, $T_{81}$, and, to a lesser extent, the ${ }^{10} \mathrm{Be}^{21} \mathrm{Ne}$ ages, $T_{10}$, are less subject to all these sources of bias (Marti, 1967; Eugster et al., 1967). Terribilini et al. (2000) obtained $T_{81}$ ages for 7 Martian meteorites. Their averages are 3\% lower than the average $T_{\mathrm{s}}$ ages. The $T_{10}$ ages, calculated for 5 Martian meteorites by several authors, are on an average also $3 \%$ lower than the $T_{\mathrm{s}}$ ages. It appears that these $T_{\mathrm{s}}$ ages have little or none of the biases mentioned above.

Figure 7a plots peak shock pressures from Table I versus ejection ages from Table IV. Both of these parameters are expected to be related to ejection of the meteorites from Mars. Most of the data, with exception of that for the nakhlites, plot within a range of shock pressures from $\sim 30 \mathrm{GPa}$ to $\sim 80 \mathrm{GPa}$ corresponding, respectively, to the pressures at which plagioclase is converted to maskelynite $\left(P_{\text {mask }}\right)$, and at which shock melting occurs $\left(P_{\text {melt }}\right)$. Melosh $(1985)$ notes that in the spallation model for meteorite ejection, the ejection velocity is proportional to the pressure gradient, not the pressure. The implication of Figure 7 is that just prior to ejection, the shock pressure due to a compressive pulse at the shergottite location had reached nearly the maximum sustainable without shock melting. Furthermore, in the context of the Melosh model, the pressure gradient due to interfering com- 
TABLE IV

Cosmic-ray exposure ages, terrestrial ages, and ejection ages of Martian meteorites in Myr.

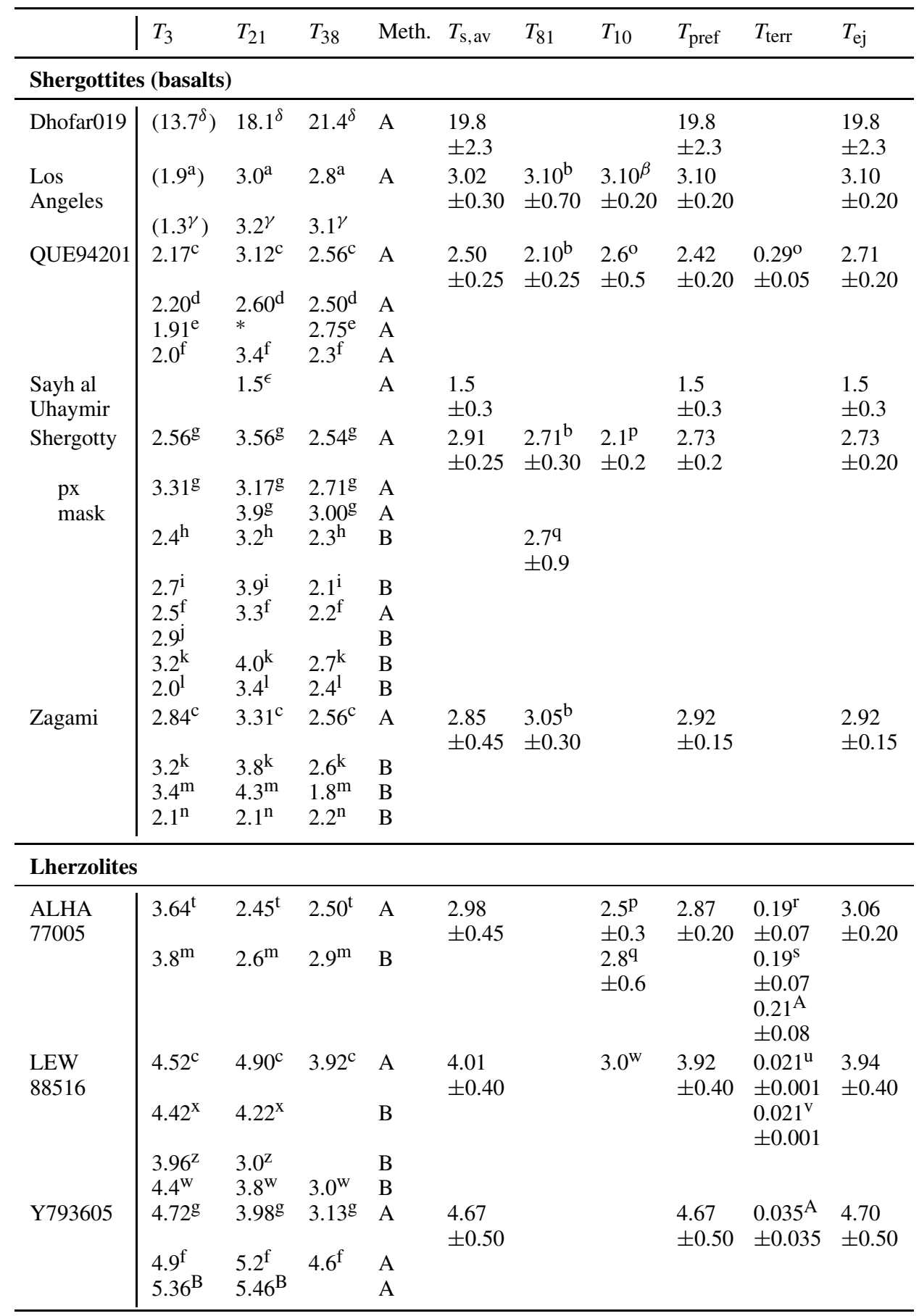


TABLE IV

(continued)

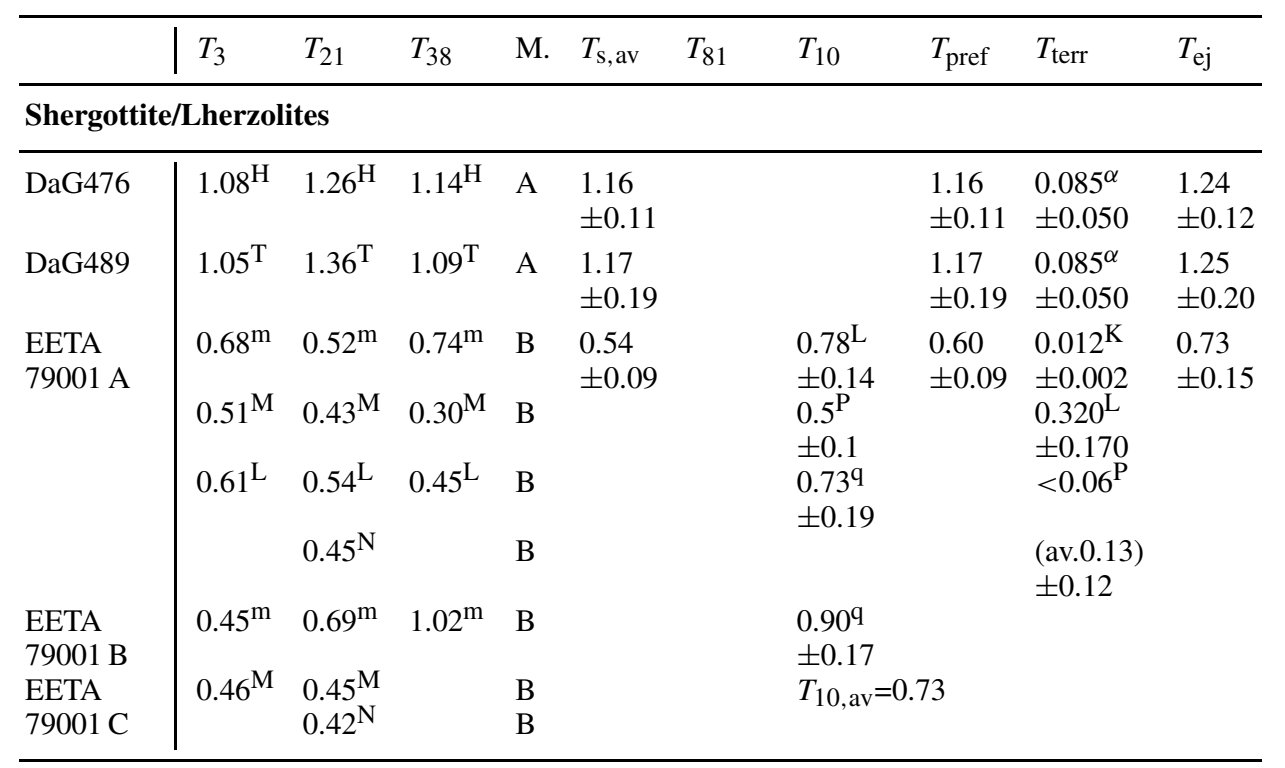

Nakhlites

\begin{tabular}{l|ccccccccc}
\hline $\begin{array}{l}\text { Governador } \\
\text { Valadares }\end{array}$ & $12.2^{\mathrm{P}}$ & $12.3^{\mathrm{P}}$ & $6.7^{\mathrm{P}}$ & $\mathrm{B}$ & $\begin{array}{l}10.0 \\
\pm 2.1\end{array}$ & & $\begin{array}{l}10.0 \\
\pm 2.1\end{array}$ & $\begin{array}{c}10.0 \\
\end{array}$ \\
& & $9.5^{\mathrm{Q}}$ & $9.2^{\mathrm{Q}}$ & $\mathrm{B}$ & & & & & \\
Lafayette & $10.1^{\mathrm{n}}$ & $12.4^{\mathrm{n}}$ & $8.8^{\mathrm{n}}$ & $\mathrm{B}$ & 11.9 & & 11.9 & $0.0089^{\mathrm{U}}$ & 11.9 \\
& & & & & \pm 2.2 & & \pm 2.2 & \pm 0.0013 & \pm 2.2 \\
& $13.7^{\mathrm{R}}$ & $16.0^{\mathrm{R}}$ & $10.3^{\mathrm{R}}$ & $\mathrm{B}$ & & & & & \\
Nakhla & $11.4^{\mathrm{i}}$ & $12.4^{\mathrm{i}}$ & $8.4^{\mathrm{i}}$ & $\mathrm{B}$ & 12.2 & $10.75^{\mathrm{b}}$ & 10.75 & 10.75 \\
& & & & & \pm 1.5 & \pm 0.40 & & \pm 0.40 & \pm 0.40 \\
& $12.1^{\mathrm{J}}$ & $12.0^{\mathrm{J}}$ & $10.6^{\mathrm{J}}$ & $\mathrm{B}$ & & & & & \\
& $14.8^{\mathrm{R}}$ & $16.0^{\mathrm{R}}$ & $12.2^{\mathrm{n}}$ & $\mathrm{B}$ & & & & & \\
\hline
\end{tabular}

\section{Dunite}

\begin{tabular}{l|llllllll}
\hline Chassigny & $13.3^{\mathrm{g}}$ & $11.1^{\mathrm{g}}$ & $10.5^{\mathrm{g}}$ & $\mathrm{A}$ & 11.6 & $10.7^{\mathrm{b}}$ & 11.3 & 11.3 \\
& & & & & \pm 1.6 & \pm 1.8 & \pm 0.6 & \pm 0.6 \\
& $14.7^{\mathrm{F}}$ & $13.9^{\mathrm{F}}$ & $7.1^{\mathrm{F}}$ & $\mathrm{B}$ & & & & \\
& $15.1^{\mathrm{E}}$ & $13.7^{\mathrm{E}}$ & $8.8^{\mathrm{E}}$ & $\mathrm{B}$ & & & & \\
& $12.3^{\mathrm{i}}$ & $11.8^{\mathrm{i}}$ & $7.1^{\mathrm{i}}$ & $\mathrm{B}$ & & & & \\
\hline
\end{tabular}

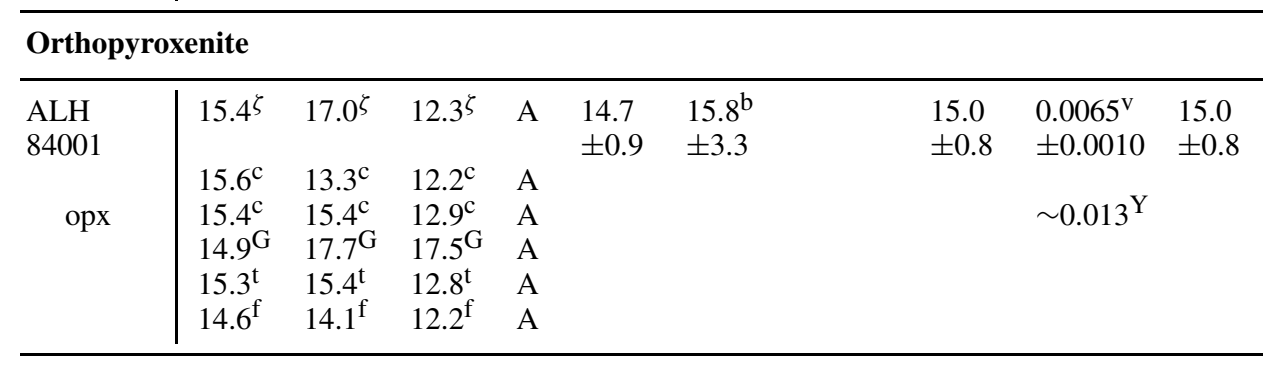




\section{Notes}

$T_{3}, T_{21}, T_{38}$ : Cosmic-ray exposure ages based on ${ }^{3} \mathrm{He},{ }^{21} \mathrm{Ne},{ }^{38} \mathrm{Ar}$ and appropriate production rates.

Meth., M.: $\quad$ Method used for calculating $T_{3}, T_{21}, T_{38}$ :

A - CRE ages as given by author(s). Applies to papers published after 1990 .

B - CRE age calculated using production rates according to Eugster and Michel (1995). Applies to papers published before 1990 and to work where authors do not give CRE ages.

$T_{\mathrm{S}, \text { av }}$ : $\quad$ Mean value of all $T_{3}, T_{21}$, and $T_{38}$ ages for a particular meteorite. Errors are $2 \sigma_{\text {mean }}$.

$T_{81}: \quad{ }^{81} \mathrm{Kr}-\mathrm{Kr}$ CRE age (Terribilini et al., 2000).

$T_{10}: \quad{ }^{10} \mathrm{Be}^{2}{ }^{21} \mathrm{Ne}$ CRE age as given by authors.

$T_{\text {pref }}: \quad$ Preferred CRE age, $T_{\text {pref }}=0.5 \times\left[T_{\mathrm{s}, \text { av }}+0.5 \times\left(T_{81}+T_{10, \text { av }}\right)\right]$. Error of $T_{\text {pref }}, \Delta T_{\text {pref }}=2 \sqrt{\sum\left(2 \Delta_{\mathrm{s}, \text { av }}^{2}+\Delta_{81}^{2}+\Delta_{10, \text { av }}^{2}\right) / 12}$

$T_{\text {terr: }} \quad$ Terrestrial age as given by authors.

$T_{\mathrm{ej}}: \quad \quad$ Mars ejection age, $T_{\mathrm{ej}}=T_{\text {pref }}+T_{\text {terr. }}$. Error of $T_{\mathrm{ej}}, \Delta T_{\mathrm{ej}}=\sqrt{\left(\Delta T_{\text {pref }}\right)^{2}+\left(\Delta T_{\mathrm{ej}}\right)^{2}}$.

\section{References}

${ }^{\mathrm{a}}$ Garrison and Bogard (2000); ${ }^{\mathrm{b}}$ Terribilini et al. (2000); ${ }^{\mathrm{c}}$ Eugster et al. (1997b); ${ }^{\mathrm{d}}$ Dreibus et al. (1996); ${ }^{\mathrm{e}}$ Swindle et al. (1996); ${ }^{\mathrm{f}}$ Garrison and Bogard (1998); ${ }^{\mathrm{g}}$ Terribilini et al. (1998); ${ }^{\mathrm{h}}$ Becker and Pepin (1986); ${ }^{\mathrm{i}}$ Ott (1988); ${ }^{\mathrm{j}}$ Eberhardt and Hess (1960); ${ }^{\mathrm{k}}$ Heymann et al. (1968); ${ }^{1}$ Müller and Zähringer (1969); ${ }^{\mathrm{m}}$ Bogard et al. (1984); ${ }^{\mathrm{n}}$ Ott (1989), unpubl. data (see Schultz and Franke, 2000); ${ }^{\circ}$ Nishiizumi and Caffee (1996); ${ }^{\mathrm{p}}$ Nishiizumi et al. (1986); ${ }^{\mathrm{q}}$ Pal et al. (1986); ${ }^{\mathrm{r}}$ Schultz and Freundel (1984); ${ }^{\mathrm{s}}$ Evans et al. (1992); ${ }^{\mathrm{t}}$ Miura et al. (1995); ${ }^{\mathrm{u}}$ Nishiizumi et al. (1992); ${ }^{\mathrm{v}} \mathrm{Jull}$ et al. (1994); ${ }^{\mathrm{w}}$ Treiman et al. (1994); ${ }^{\mathrm{x}}$ Becker and Pepin (1993); ${ }^{\mathrm{z}}$ Ott and Löhr (1992); ${ }^{\mathrm{A}}$ Nishiizumi and Caffee (1997); ${ }^{\mathrm{B}}$ Nagao et al. (1997); ${ }^{\mathrm{D}}$ Bogard (1995); ${ }^{\mathrm{E}}$ Lancet and Lancet (1971); ${ }^{\mathrm{F}}$ Schultz and Signer (1973), unpublished; G Swindle et al. (1995); ${ }^{\mathrm{H}}$ Zipfel et al. (2000); J Stauffer (1962); $\mathrm{K}$ Jull and Donahue (1988); ${ }^{\mathrm{L}}$ Sarafin et al. (1985); ${ }^{\mathrm{M}}$ Becker and Pepin (1984), for $R=35$ to $>1000$ and $d=6-80 \mathrm{~g} / \mathrm{cm}^{2}$; ${ }^{\mathrm{N}}$ Swindle et al. (1986); ${ }^{\mathrm{P}}$ Bogard and Husain (1977); Q Swindle et al. (1989); ${ }_{\mathrm{R}}$ Ganapathy and Anders (1969); ${ }^{\mathrm{T}}$ Folco et al. (1999), same production rates used as for DaG476; U Jull et al. (1997); Y Jull et al. (1995); ${ }^{\alpha}$ Nishiizumi et al. (1999; same $T_{\text {terr }}$ for the paired meteorites DaG476/489); ${ }^{2}{ }^{21} \mathrm{Ne}$ and ${ }^{10} \mathrm{Be}$ data from Garrison and Bogard (2000) and Nishiizumi and Masarik (2000), respectively; ${ }^{\gamma}$ Lorenzetti and Eugster (2001); ${ }^{\delta}$ Shukolyukov et al. (2000); $\epsilon$ Paetsch et al. (2000); $\zeta$ Eugster (1994).

pressive and tensile pulses, the latter reflected from the free surface of the planet, is sufficient to accelerate ejecta to escape velocity. These conditions define an annulus around the impact site from which material is ejected ( $c f$. Warren, 1994).

From Figure 7a there appear to be 7 ejection events: at $\sim 20,15,12,4.5,3$, 1.3 and $0.7 \mathrm{Myr}$, respectively. Five of the total are for either basaltic or lherzolitic shergottites, suggesting that shergottites must be widespread on the Martian surface, or that the ejection mechanism preferentially selects basaltic compositions. Interestingly, both the oldest and the youngest events are for shergottites: Dhofar 019 at $\sim 20 \mathrm{Myr}$ ago, and EET79001 at $\sim 0.7 \mathrm{Myr}$ ago. 


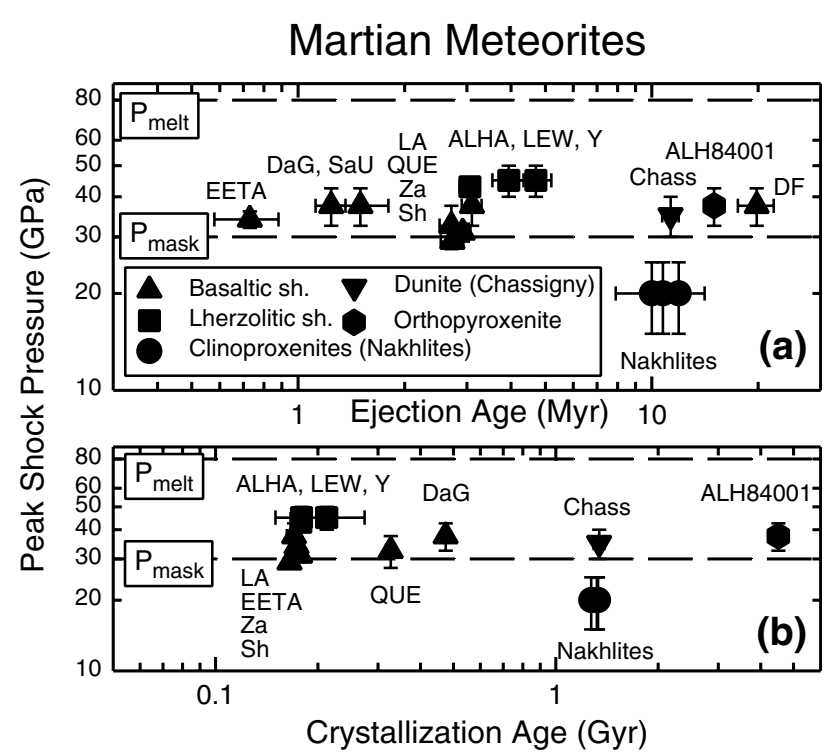

Figure 7. Peak shock pressures in Martian meteorites vs. their a) ejection ages and b) crystallization ages (EETA: EETA79001; DaG: Dar al Gani476; SaU: SaU005; LA: Los Angeles; QUE: QUE94201; Za: Zagami; Sh: Shergotty; ALHA: ALHA77005; LEW: LEW88516; Y: Y793605; Chass: Chassigny); DF: Dhofar019). Shock pressure data from Stöffler et al. (1986) and Stöffler (2000) except for SaU, LA, and DF (this paper; Table I); age data from Tables II, III, and IV (see references there). $P_{\max }$ and $P_{\text {melt }}$ are the approximate peak shock pressures at which plagioclase is converted to maskelynite and basalts are shock-melted, respectively.

The picture changes somewhat when shock pressures are plotted against the crystallization ages of the meteorites (Figure 7b). To the extent that different Martian surface units are composed of rocks of distinct crystallization ages, both crystallization ages and ejection ages might be viewed as "event discriminators". Nearly the entire Martian surface has been classified according to relative age as determined from the density of meteorite impact craters per unit area. These "crater retention ages" reflect ca. the upper $1 \mathrm{~km}$ of near-surface layers, so that lava flows of a variety of absolute ages may be present in a given area (Hartmann, 1999). Nevertheless, the crater retention ages provide a Martian context in which to view the potential number of ejection events. In this context, there appear to be only 4-5 events: one on old terrain, one on terrain of intermediate-to-young $1.3 \mathrm{Gyr}$ age, 1 or 2 on young-to-intermediate, $0.3-0.5$ Gyr terrain, and one on very young, $\sim 0.18$ Gyr terrain. The crystallization ages of Dhofar019 and SaU005 are not available yet, and might define additional events, possibly bringing the total to 6-7 separate events. More realistically, the total is apt to increase by no more than one, since SaU005 appears to be paired in ejection age with DaG476. Nevertheless, 7 meteorites, more than half of those for which crystallization ages have been determined, derive from $\sim 0.18 \mathrm{Gyr}$ terrain. This presents an apparent "paradox" of too many young meteorites from too little young Martian terrain (Nyquist et al., 1998). 


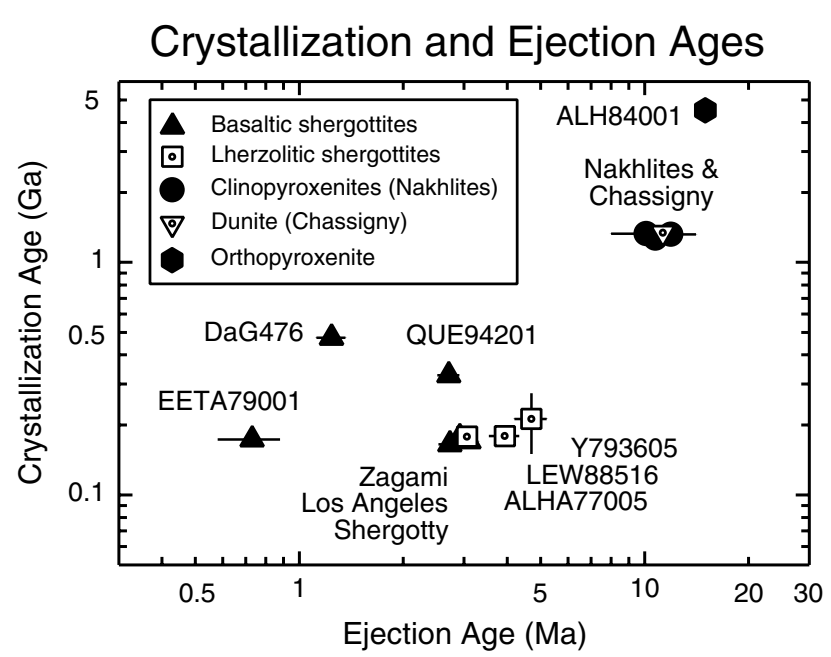

Figure 8. Preferred values of the crystallization ages of the Martian meteorites (Tables II and III) plotted vs. the ejection ages of the meteorites (Table IV).

Figure $7 \mathrm{~b}$ seems to show that meteorites ejected in a given event may experience a variety of peak shock pressures, as shown for the "nakhlite-chassignite" and "young shergottite" events, respectively.

Figure 8 plots the crystallization ages of the Martian meteorites directly versus their ejection ages. SaU005 and Dhofar019 are two important omissions, particularly because the Dhofar019 event $19.8 \pm 2.3 \mathrm{Myr}$ ago on basaltic shergottite terrain is the oldest event of which we have record. The next event, which ejected ALH84001 from old (Noachian) terrain $15.0 \pm 0.8 \mathrm{Myr}$ ago, is clearly identified. ALH84001 apparently experienced a peak shock pressure of $\sim 35-40 \mathrm{GPa}$ on ejection, typical for Martian meteorites. This rock of initially deep-seated origin must have been previously moved to its place of ejection, probably a few meters to tens of meters beneath the Martian surface, assuming it came from just beneath the spall zone of an impactor $\sim 1-10 \mathrm{~km}$ in diameter (Melosh, 1984; 1985). This is consistent with its complicated shock history, consisting of two or more stages.

The next ejection event was the nakhlite event. The nakhlites, Governador Valadares, Lafayette, and Nakhla, were recovered at three widely separated localities: Egypt, Brazil, and Indiana. They are clinopyroxenites, have the same radiometric crystallization ages, and the same ejection age of $\sim 11.4$ Myr. The dunite, Chassigny, is a fourth meteorite with a $\sim 1.3$ Gyr crystallization age and an ejection age of $11.3 \pm 0.6 \mathrm{Myr}$. Its radiogenic isotope composition and the abundances of several key incompatible trace elements suggest a close relationship to the nakhlites. Although Chassigny is mineralogically distinct from the nakhlites, it probably was ejected simultaneously with them. If so, it and the nakhlites probably were previously moved to their place of ejection. If, however, they crystallized near the center of a $\sim 100 \mathrm{~m}$ thick flow (Treiman, 1987), they may have been ejected directly by 
a large event. Alternatively, they may have experienced a two-stage shock history, with the earlier, lighter shock overprinted by the shock of the ejecting impact. In any case, early Amazonian Martian terrain, on the HT timescale, appears to have been sampled only once. We call this the NC event following Treiman (1995a).

The shergottites present the greastest puzzle. Taken at face value, the CRE ages indicate 4 ejection events within $5 \mathrm{Myr}$ on terrain of three different, young, crystallization ages. Four basaltic shergottites, Shergotty, Zagami, Los Angeles, and QUE94201, have ejection ages in a narrow range of 2.7-3.1 Myr, and one lherzolitic shergottite, ALH77005, has a similar ejection age of $3.06 \pm 0.20 \mathrm{Myr}$. The ejection ages of two other lherzolites (3.94 \pm 0.40 Myr for LEW88516 and $4.70 \pm 0.50 \mathrm{Myr}$ for Y793605), however, do not overlap with those of the basaltic shergottites. The exposure ages of the three lherzolites are somewhat uncertain because of uncertainty in production rates, and because no ${ }^{81} \mathrm{Kr}$ ages yet exist. Further, ALH77005 and LEW88516 are similar in several properties (Treiman et al., 1994) and might be expected to have the same ejection age. Thus, the differences in ejection ages among these three lherzolites are not easily interpreted.

Let us consider a scenario in which these 4 shergottites and the 3 lherzolites were ejected in a single event, and assume that the higher ages of LEW88516 and Y793605 are due to an exposure to cosmic rays prior to ejection from Mars (Nagao et al., 1997). Nishiizumi and Caffee (1997) also concluded that for Y793605 it is not possible to completely eliminate, based on radionuclide activities, the possibility of a pre-irradiation on the surface of the parent body. On the other hand, Treiman et al. (1994) found from the radionuclide activities of LEW88516 that most of its cosmic-ray exposure probably occurred as an individual meteoroid. Furthermore, the cosmogenic ${ }^{22} \mathrm{Ne} /{ }^{21} \mathrm{Ne}$ ratios are $1.227 \pm 0.035$ for LEW88516 (Eugster et al., 1997a) and $1.207 \pm 0.020$ for Y793605 (Terribilini et al., 1998), indicating irradiation as small bodies for the total duration of exposure. A complicated exposure history beginning with excavation of LEW88516 and Y793605, followed by ejection within 1-2 Myr, or reburial of these two rocks between their initial excavation and ejection, seems improbable. Nevertheless, the shock features of Y793605 do suggest a two-phase shock history. These plutonic rocks probably crystallized at considerable depth, and were relocated to the ejection site. Peak shock pressures for all three are the highest among the Martian meteorites, suggesting that they were excavated from deeper depths than the other shergottites, and thus that they were more heavily shielded against cosmic-ray irradiation immediately prior to ejection. Nevertheless, the more brecciated texture of Y793605 suggests that it may have spent some time in a relatively shallow surface location. Thus, it may have acquired some cosmogenic noble gases between its first and second shock, the latter being coincident with its ejection from Mars. Nearly identical crystallization ages of $179 \pm 5 \mathrm{Myr}$ and $178 \pm 8 \mathrm{Myr}$, respectively, for ALH77005 and LEW88516 (Table III), raise the possibility that all the lherzolites were ejected simultaneously with ALH77005, Shergotty, Zagami, and Los Angeles, even though the "ejection ages" of LEW88516 and Y793605 are analytically resolved from the others. 
Additional events seem to be required for the shergottites/lherzolites DaG476 and 489, and EET79001. The ejection ages for EET79001, DaG476, and DaG489, are $0.73 \pm 0.15 \mathrm{Myr}, 1.24 \pm 0.12 \mathrm{Myr}$, and $1.25 \pm 0.20 \mathrm{Myr}$, respectively. DaG476 and 489 are likely to be part of a single fall, so the coincidence of their ejection ages is not surprising. The ages of DaG476/489 do not appear to overlap that of EET79001, and are clearly younger than those for the shergottites and the lherzolites. Zipfel et al. (2000) derive a slightly older ejection age of $1.35 \pm 0.10 \mathrm{Myr}$ for DaG476. In any event, its old crystallization age of $\sim 474$ Myr indicates a separate ejection event for it. The ejection age of EET79001 has some ambiguity. Most CRE ages for EET79001 have been determined for lithology A, leading to a preferred value $T_{\text {pref }}=0.60 \pm 0.09 \mathrm{Myr}$ (Table IV). This value, when combined with the averaged terrestrial age of $0.13 \pm 0.12 \mathrm{Myr}$, yields $T_{\mathrm{ej}}=0.73 \pm 0.15 \mathrm{Myr}$ (Table IV). A significantly higher value of $1.22 \pm 0.24 \mathrm{Myr}$ would be obtained, however, by combining the ${ }^{10} \mathrm{Be}-{ }^{21} \mathrm{Ne} \mathrm{CRE}$ age of $0.90 \pm 0.17 \mathrm{Myr}$ for EET79001 lithology B (Pal et al., 1986) with the terrestrial age of $0.32 \pm 0.17 \mathrm{Myr}$ reported for EET79001 (Sarafin et al., 1985). This is the highest value derivable from the EET79001 data and is in good agreement with the preferred ejection age of DaG476 (Table IV). Thus, the resolution of the EET79001 and DaG476 ages may not be completely established. The disparity in apparent ejection ages of lithologies A and B of EET79001 may be related to the chemical differences between them, which affect the spallation nuclide production rates used to calculate CRE ages.

\section{Provenance of the Martian Meteorites}

\subsection{Alternative Ejection Scenarios}

Inconsistent numbers of Martian ejection events are inferred from crystallization and CRE ages, respectively. One may argue, that either some of the CRE ages are due to secondary collisions after ejection from Mars, or that there are vast expanses on Mars that not only are "young", but are the same age, within current experimental uncertainty. In the following, we characterize these two approaches.

\subsubsection{Cosmic-Ray Exposure Events: Without Secondary Collisions}

This assumption takes the ejection ages at face value (Eugster et al., 1997b). Figures $7 \mathrm{a}$ and 8 show the following events: $\mathrm{S}_{\mathrm{Dho}}$ (Dhofar019 shergottite), O (orthopyroxenite), NC (nakhlites and Chassigny), $S_{\mathrm{L}}$ (lherzolitic shergottites, especially LEW88516 and Y793605), S (traditional basaltic shergottites), $\mathrm{S}_{\mathrm{DaG}}$ (DaG476/489 and SaU005), and $\mathrm{S}_{\mathrm{E}}$ (EET79001). These 7 events include 5 related to shergottites. Three of these are on terrain $<500 \mathrm{Myr}$ old. A modification of this scenario might allow an additional event, $\mathrm{S}_{\mathrm{Q}}$, for QUE94201 because of its unique crystallization age. Thus, in this scenario there are 7-8 ejection events, 5-6 of which are for shergottites $<\sim 500 \mathrm{Myr}$ old, and three include shergottites $\sim 175 \mathrm{Myr}$ old. 


\subsubsection{Events Based On Crystallization Age: Cosmic-Ray Exposure With Secondary Collisions}

Nyquist et al. (1998) preferred the term "small body ages" to "ejection ages" to emphasize that the event directly dated was initiation of exposure of "small" bodies to cosmic radiation. "Small" was defined by Bogard et al. (1984) as $<\sim 6 \mathrm{~m}$ as a safe upper limit. A practical definition of "small" is that size below which a twostage exposure becomes detectable in the total radionuclide and stable spallation nuclide data. This size is difficult to quantify, but is apt to be somewhat smaller, perhaps 3-4 $\mathrm{m}$ in diameter. In a "strong" version of this model, some CRE ages may be unrelated to the actual ejection events. In this case, the minimum number of events suggested by the crystallization age data are: $\mathrm{O}, \mathrm{NC}$, and $\mathrm{S}$ (Nyquist $e t$ al., 1998). An additional two events $S_{Q}$, and $S_{D a G}$, might be allowed because the crystallization ages of QUE94201 and DaG476 differ from $~ 175 \mathrm{Myr}$, and another two events may be permissible because precise crystallization ages of Dhofar019 and SaU005 are not yet available. The whole rock Sm-Nd data (Figure 6), and initial Sr- and Nd-isotopic data (not shown) suggest that DaG476, QUE94201, and Dhofar 019 constitute a suite of samples separate from the $\sim 175 \mathrm{Myr}$ shergottites. Treiman (1995a) considered a larger array of petrologic, chemical, and chronological data, and suggested two distinct sites of origin for the then known SNC meteorites, which did not include QUE94201, DaG476/489, or Dhofar019. Thus, the probable number of events in this scenario is $\geq 4$ : O, NC, $S_{1}$, and $S_{2}$, where subscripts 1 and 2 separate the $\sim 175 \mathrm{Myr}$ shergottites from $\sim 300-500 \mathrm{Myr}$ shergottites. Subgroup $S_{2}$ may be further sub-divided into as many as three. The $\sim 3 \mathrm{Myr}$ exposure age for QUE94201 perhaps should exclude it from $\mathrm{S}_{2}$. Also, $\mathrm{SaU} 005$ is almost certainly paired with DaG476/489 on the basis of their CRE age. Note that for 4-6 ejection events the "secondary collision" hypothesis is required to hold only in a "weak" form for the young exposure age of EET79001. In that case, ejection events would have occurred at $\sim 20 \mathrm{Myr}, \sim 15 \mathrm{Myr}, \sim 12 \mathrm{Myr}, \sim 3 \mathrm{Myr}$, and $\sim 1.3 \mathrm{Myr}$, respectively, assuming that some of the lherzolitic shergottites had some exposure on the Martian surface.

That half or more of the total number of Martian meteorite ejection events yielded shergottites $<\sim 500 \mathrm{Myr}$ old continues to be a paradox. According to new spacecraft observations, very late lava flows appear to cover an area of $\sim 10^{8} \mathrm{~km}^{2}$ (Keszthelyi et al., 2000), 7\% of the total area of Mars, or $\sim 12 \%$ of the volcanic surface area (Tanaka et al., 1992). The previously recognized Late Amazonian volcanic surface was only $\sim 3.3 \times 10^{6} \mathrm{~km}^{2}$ (Tanaka et al., 1992), so the apparent over-representation of shergottite-ejection events compared to the total number of events and to the number of orthopyroxenite and nakhlite events persists. This shergottite age paradox (Nyquist et al., 1998) is most pronounced for scenarios involving no secondary collisions in meteorite transit from Mars. That is, the probability that of $3-4$ random events, at $\sim 4.3(?), \sim 3.0, \sim 1.3$, and $\sim 0.7 \mathrm{Myr}$ ago, 2-3 ejected meteorites having indistinguishable crystallization ages within an analytical precision of a few percent, would seem to be very low. If these are 
truly separate, random, events, there must be great expanses of $\sim 175$ Myr lavas on the Martian surface. Keszthelyi et al. (2000) noted that the $\sim 10^{7} \mathrm{~km}^{2}$ of newly recognized flood basalts in Elysium and Amazonis Planitia is an area roughly the size of Canada. The age paradox appears to require an even larger area; i.e., $\sim 50 \%$ of the $84 \times 10^{6} \mathrm{~km}^{2}$ total volcanic surface area of Mars (Tanaka et al., 1992) appears to be required to be $<\sim 500 \mathrm{Myr}$ old, and $\sim 2 / 3-3 / 4$ of that to be $\sim 175 \mathrm{Myr}$ basalt if the events at $\sim 4.3, \sim 3.0$, and $\sim 0.7$ are due to separate, random impacts on the Martian surface. The fewer the number of shergottite ejection events, the more easily reconcilable is their number with the Martian cratering record, and the number of nakhlite and orthopyroxenite ejection events (one each).

Finally, it should be noted that Martian surface ages are derived by scaling an assumed Martian cratering rate as a function of time to the lunar cratering rate as a function of the absolute ages of lunar surfaces as determined on returned lunar samples. Hartmann (1999) estimates the uncertainty in this process to be on the order of a factor of three. If the Martian cratering rate were higher than assumed in Tanaka et al. (1992), the apparent ages of Martian surface units would be shifted to lower values. Surface terrain of age $\sim 1.3 \mathrm{Gyr}$, assumed to be present in the Early Amazonian on the HT model, and representing 9\% of the volcanic surface of Mars, would actually be found in the Late Hesperian, representing $\sim 14 \%$ of the volcanic surface. Surface terrain of $\sim 0.5 \mathrm{Gyr}$ or less, found in the Middle and late Amazonian in the HT model, would be shifted to Early Amazonian, representing $\sim 15 \%$ of the volcanic surface. Together they would represent a sizeable fraction of the total surface $(\sim 29 \%)$, and a significant probability that Martian meteorites would be $\leq 1.3 \mathrm{Gyr}$ old. Even in this case, however, the relative frequency of shergottite events to nakhlite events would be expected to be only $\sim 1: 1$.

Mars may have been more active in recent times than previously thought, and late, thin lava flows may be relatively ubiquitous on the Martian surface, increasing the probability of young meteorites. Clarification of whether the ages of the meteorites are in proportion to the exposed area of young surfaces, however, will require a) continued and refined chronological studies of the Martian meteorites; b) absolute calibration of the Martian crater-frequency curve via returned Martian samples; c) more high resolution imagery of the Martian surface; and d) evaluation of the compositional biases, if any, that may exist in the yield of meteorites from surfaces of different compositional types.

\subsection{Potential Source Terrains}

Several authors have sought to identify potential Martian source terrains and candidate source craters for the Martian meteorites (Nyquist, 1983; Mouginis-Mark et al., 1992; Treiman, 1995a; Barlow, 1997; Nyquist et al., 1998). Such attempts have relied primarily on the crystallization ages of the meteorites and the perceived characteristics of the resulting impact craters. Mouginis-Mark et al. (1992) identified 9 candidate source craters for the SNC meteorites on the Tharsis plains of 
Mars, the only area of the planet seen to have lava flows $\leq 1.3 \mathrm{Gyr}$ old on the HT model using Viking imagery. The higher resolution imagery from the Mars Global Surveyor (MGS) has shown the presence of thin, nearly craterless, lava flows on areas that are more heavily cratered at the Viking resolution, however (Hartmann, 1999; Hartmann and Berman, 2000). These new observations significantly extend the Martian surface area known to be covered by young basalts, as well as lower some cratering ages into the range of the ages of SNCs by either model. Crater densities on these young lavas are $10^{-3}$ to $10^{-2}$ times the densities on lunar maria of ages $\sim 3.5 \mathrm{Gyr}$, so that some Martian basalts appear to be as young as $\sim 10 \mathrm{Myr}$ or less (Hartmann and Berman, 2000).

\subsection{IMPLiCATIONS OF EJECTION MODELS}

Three recent developments loosen the restrictions on possible source terrains for the shergottites: a) The MGS data show young, thin, lava flows covering older flows in some localities, particularly in Elysium and Amazonis Planitia (cf. Keszthelyi et al., 2000). b) The older crystallization ages of $\sim 330 \mathrm{Myr}$, and $\sim 475 \mathrm{Myr}$ found for QUE94201 and DaG476, respectively, further extend the potential source terrains. c) The lower theoretical limiting crater size for meteorite ejection of $\geq 3 \mathrm{~km}$ (Head and Melosh, 2000) increases the number of candidate source craters, as compared to those $\geq 10 \mathrm{~km}$ (Mouginis-Mark et al., 1992).

The decrease in crater size required for meteorite ejection according to the Melosh (1984) spallation model greatly increases the number of fragments potentially ejected from Mars. According to Mileikowsky et al. (2000) the number of fragments ejected from craters $\sim 13 \mathrm{~km}$ diameter on Mars with shock pressures $<1 \mathrm{GPa}$ over $4 \mathrm{Gyr}$ is $9.5 \times 10^{10}$. They estimate the number ejected at $<1 \mathrm{GPa}$ is about $2 \%$ of the total. For craters of this size, the mean ejecta fragment diameter is $\sim 0.3 \mathrm{~m}$. These values may be compared to $\sim 9.4 \times 10^{9}$ fragments of mean diameter $\sim 0.9 \mathrm{~m}$ and shock pressure $<1 \mathrm{GPa}$ for a $30 \mathrm{~km}$ diameter crater, and $\sim 2.0 \times 10^{\S}$ fragments of mean diameter $\sim 3 \mathrm{~m}$ and shock pressure $<1 \mathrm{GPa}$ for a $\sim 100 \mathrm{~km}$ diameter crater. The maximum fragment diameter is estimated to be about four times the mean diameter. The spallation model thus favors a high proportion of small meteorites, with the relative abundance falling off by more than 2 orders of magnitude for an order of magnitude increase in size. Although there is a high proportion of small meteorites among the lunar meteorites, small meteorites do not seem to be preferred among Martian meteorites ( $c f$. Warren, 1994).

The largest Martian meteorite, Nakhla, has a recovered mass of $40 \mathrm{~kg}$, corresponding to a spherical meteoroid $\sim 0.3 \mathrm{~m}$ in diameter. This, of course, is a lower limit on the pre-atmospheric size of Nakhla. Although $0.3 \mathrm{~m}$ is not large in an absolute sense, it is $\sim 60$ times larger in mass, or $\sim 4$ times larger in radius, than the largest lunar meteorite (Warren, 1994), implying proportionally larger impactors. For the spallation model, Mileikowsky et al. (2000) give fragment size $l=3 \times 10^{-4} L$, where $L$ is the impactor diameter. Since this scales as $V_{\mathrm{ej}}^{-2 / 3}$, 
where $V_{\mathrm{ej}}$ is the ejection velocity, we expect $l_{\text {Mars }} / l_{\text {Moon }} \sim 1.6$, implying moderately larger Martian launch craters than lunar launch craters. A much more significant difference would be implied if a "proto-EET79001" $3 \mathrm{~m}$ in diameter is required for later involvement in a secondary collision. A fragment this large would be at the upper size limit for a $30 \mathrm{~km}$ crater. A larger crater, $\sim 100 \mathrm{~km}$ in diameter, is inferred from the spallation model if the mean fragment size is to be $\sim 3 \mathrm{~m}$.

From Gladman (1997; Figure 11), we estimate that a Martian meteorite ejected $4 \mathrm{Myr}$ ago would on average spend $\sim 0.15 \mathrm{Myr}$ in the main asteroid belt, where the collision rate is relatively high. Wetherill (1988) gave the half-life, $\tau$ (Myr), against collision in the main belt as $\tau \sim 1.2 r^{1 / 2}$ for meteoroids of radius $r(\mathrm{~cm})$. Thus, for $r=150 \mathrm{~cm}, \tau$ is $15 \mathrm{Myr}$, and on average $\sim 1 \%$ of objects launched $4 \mathrm{Myr}$ ago would undergo secondary collisions in the main belt. If a large number of fragments were launched simultaneously, as implied by recovery of 3-7 individuals from the shergottite $(\mathrm{S})$ event, then the probability that one of those individuals would have undergone a secondary collision would be $\sim 3-7 \%$. Thus, the possibility of secondary collisions in space after ejection of meterorites from Mars cannot be discounted a priori. As noted earlier in the paper, crystalline rock fragments from the $\sim 25 \mathrm{~km}$ diameter Ries crater shocked to the range of the Martian shergottites do not exceed a size of $\sim 0.5 \mathrm{~m}$. Fragment size should scale as the product of dynamic tensile strength and projectile diameter (Melosh, 1985). An increase in this product of a factor of $\sim 6$ or more for the Martian source crater of the shergottites compared to the Ries would appear to be required to yield proto-EET79001 fragments.

Mileikowsky et al. (2000) have estimated the minimum crater size theoretically consistent with proto-EET79001s of $\sim 3 \mathrm{~m}$ at $\sim 30 \mathrm{~km}$. For $\sim 0.3 \mathrm{~m}$ fragments, their estimate of an $\sim 13 \mathrm{~km}$ final crater diameter is in close agreement with $\sim 15 \mathrm{~km}$ estimated by Warren (1994) for Nakhla. This is $\sim 15$ times larger than the largest source craters Warren estimates for the lunar meteorites on the same basis, an unexpected difference considering $l_{\text {Mars }} / l_{\text {Moon }} \sim 1$.6. Warren (1994) also estimates that a crater $\sim 11 \mathrm{~km}$ in diameter is required to launch the largest shergottite, Zagami. Thus, the relatively large size of the Martian meteorites may indicate derivation from relatively large craters, in spite of the lowering of the theoretical limit of the Melosh $(1984,1985)$ model for the smallest crater required for launch.

\subsubsection{Implications of the Apparent Shock Pressure Launch Window}

The observation of an apparent "launch window" of peak shock pressures for the Martian meteorites may have implications for their launch mechanism and provenance. Early attempts to account for the existence of Martian meteorites sought the explanation in unusual, relatively rare, events because conventional cratering theory did not account for them. It was argued, for example, that ejection velocities could not exceed twice the "particle velocity" produced in a compressive wave at the peak shock pressures the meteorites had experienced. This maximum velocity could be achieved only at a free surface. Stöffler et al. (1986) gave the particle velocities according to the Hugoniot equation of state for the then known shergottites 
as $\sim 1.5-2.0 \mathrm{~km} / \mathrm{s}$ for peak shock pressures of $29-43 \mathrm{GPa}$, corresponding to ejection velocities of $3-4 \mathrm{~km} / \mathrm{s}$. The additional meteorites included here widen the "launch window" to $\sim 20-45 \mathrm{GPa}$, corresponding to particle velocities of $0.8-2.2 \mathrm{~km} / \mathrm{s}$ for the range of materials involved. Thus, their free surface launch velocities are $\sim 1.6-4.4 \mathrm{~km} / \mathrm{s}$, and are below Martian escape velocities.

Nyquist (1983) suggested that vapor drag might provide the needed acceleration, especially in "richocheting", very oblique angle, impacts. Numerical simulations supported the idea that oblique impacts could launch meteorites from planets (O'Keefe and Ahrens, 1986). Vickery (1986) considered a range of possibilities involving vapor phase acceleration, and concluded that if the proto-SNCs had diameters of a few centimeters or less, gas acceleration from a 30-km-diameter crater would be consistent with their ejection from Mars. Interestingly, the equivalent spherical radii of Martian meteorites corresponding to their recovered masses are in the range $\sim 2-30 \mathrm{~cm}$. Larger craters would give higher final velocities. For example, at a launch position, $x$, one crater radius, $r_{\mathrm{p}}$, from the point of impact, $0.5 \mathrm{~m}$ rocks would be accelerated by factors of $\sim 1.7$ for a $30 \mathrm{~km}$ diameter crater and of $\sim 2.9$ for a $130-\mathrm{km}$ crater. Vickery concluded that these factors, combined with the distribution of spall velocities at $x / r_{\mathrm{p}}=1$ according to the Melosh (1984) model, would not result in velocities exceeding the Martian escape velocity. In fact, the effect of gas drag at $x / r_{\mathrm{p}} \leq 0.4$ was to decelerate "ejecta" from the spall model. Thus, vapor drag did not appear to augment the number of meteorites ejected compared to those ejected by spallation alone. Nevertheless, when applied to possible free surface launch velocities of $\sim 3-4 \mathrm{~km} / \mathrm{s}$ for the shergottites, these factors result in velocities $\geq 5 \mathrm{~km} / \mathrm{s}$, as required for launch from Mars. Thus, vapor drag should not be ignored as a potential acceleration mechanism.

The oblique impact hypothesis has the attractive feature that craters produced by this process have a distinctive "butterfly" morphology that allows them to be identified. Nyquist (1983) and Nyquist et al. (1998) identified some candidate oblique impact source craters for the SNC meteorites, whereas Barlow (1997) identified a candidate oblique impact source crater for the orthopyroxenite ALH84001. Recently, attention has fallen on the Chicxulub "K-T impact" crater as of probable oblique impact origin. Schultz and D'Hondt (1996) show a time-lapse photographic sequence of the evolution of an impact-generated vapor cloud as well as summarizing the evidence for Chicxulub as an oblique impact. Hydrocode modeling of Chicxulub (Pierazzo and Melosh, 1999) and of oblique impacts more generally (Pierazzo and Melosh, 2000) describe the development of downstream melt and vapor plumes in such impacts. If surface fragments of Mars were launched into such oblique impact vapor plumes at velocities close to the escape velocity, perhaps some would acquire the "boost" needed for launch. Kadano and Fugiwara (1996) experimentally verified that for nylon projectiles impacting $\mathrm{Cu}$ targets, solid ejecta fragments are accelerated to velocities approaching that of the expanding vapor cloud. Continued studies should show whether oblique impacts could have a significant role in launching Martian meteorites. 
However, the spallation model of Melosh (1984) is most widely considered. Warren (1994) applied it in detail to the launch of both lunar and Martian meteorites. In general the model worked well for lunar meteorites, with some modification to account for the high abundance of regolith breccias and the shallow launch depths of the lunar meteorites. There are no regolith breccias among the Martian meteorites, however. In other respects, also, including a preponderance of small meteorites relative to larger ones, and a majority of unshocked meteorites relative to moderately to highly shocked ones, the spallation model matches the lunar meteorites better than the Martian meteorites.

In the spallation model, interference of a reflected rarefaction wave from the free planetary surface with the direct compressive wave reduces shock pressures in a zone of interference, where near-surface material can be ejected at high velocity without experiencing high compressive shock pressures. Spalls form at the boundary of the interference zone with a lower "free-field" zone. In the "hydrodynamic ejection model" (Melosh, 1984, 1985, 1989), the ejection velocity is given as

$$
V_{\mathrm{ej}} \approx 2 V_{\mathrm{p}}(r)\left[1+(s / d)^{2}\right]^{-1 / 2}
$$

which reproduces Equation 5.5.3 of Melosh (1989). Here, $V_{\mathrm{p}}(r)$ is the particle velocity in the compressive shock at a distance $r=\left(s^{2}+d^{2}\right)^{1 / 2}$ from the "equivalent center" of the impact. The horizontal distance $s$ is measured across the surface from the impact site to the ejection site. In analogy to nuclear explosions, $d$ is the "equivalent depth of burst." The particle velocity varies with distance according to

$$
V_{\mathrm{p}}(r) \approx C_{v}(U / 2)(a / r)^{1.87}
$$

Here, $U$ is the velocity of an impactor of mean radius $a$, and $C_{v} \sim 1$ is a "coupling constant." The equivalent depth of burst is given approximately by

$$
d \approx 2 a\left(\rho_{\mathrm{P}} / \rho_{\mathrm{t}}\right)
$$

Here, $\rho_{\mathrm{P}}$ and $\rho_{\mathrm{t}}$ are the projectile and target densities.

For $s=0$, Equation (1) appears to give the "velocity doubling rule" for free surfaces, i.e., ejection velocity equal to twice the particle velocity. However, particle velocities corresponding to the observed peak shock pressures would lead to ejection velocities of only $\sim 1.6-4.4 \mathrm{~km} / \mathrm{s}$ for the Martian meteorites, as mentioned earlier. Equation (1) can only lead to ejection velocities in excess of $5.0 \mathrm{~km} / \mathrm{s}$ if the theoretical particle velocity of Equation (2) is decoupled from the empirical particle velocity inferred from the peak shock pressures experienced by the meteorites. In this model, this "decoupling" of theoretical and empirical values of particle velocity is due to the interference of the compression and rarefaction waves.

Launch acceleration is proportional to the upward component of the pressure gradient acting on a volume of material ( $c f$. , Melosh, 1984, 1989). Let the peak shock pressure in the compressive wave be $P_{\mathrm{cw}}$, that in the rarefaction wave $P_{\mathrm{rw}}$, and the resultant pressure in the zone of interference be $P_{\text {res }}$. Because the compressive wave arrives first at a given point in the target, $P_{\text {res }}$ rises from zero as the 
compressive wave approaches, attains a maximum value, $P_{\max }<P_{\mathrm{cw}}$ as the tensile wave arrives, falls to a value $P_{\text {ten }}$, limited by the tensile strength of the material, as the maximum of the of the compressive wave passes, and finally returns to zero as the tensile wave passes ( $c f$. ., Melosh, 1985, Figure 3). The empirical particle velocities corresponding to peak shock pressures registered in the meteorites are those corresponding to $P_{\text {res }}$, whereas the particle velocity $V_{\mathrm{p}}$ in Equation (1) corresponds to $P_{\mathrm{cw}}$ of the compressive wave. Thus, in the interference zone very near the free surface, the velocity-doubling rule no longer applies, and further, as noted by Melosh (1985), the ejection velocity "is exactly twice the particle velocity in the compression wave only at the (unphysical) point on the surface lying directly above the equivalent center."

The complete decoupling of theoretical and empirical particle velocities appears to apply for lunar, but not for the Martian meteorites, in which the observed shock levels are at least partially coupled to the ejection phenomenon (Figure 7). Only a boost in acceleration above that recorded in the Martian meteorites is needed for their ejection, accomplishable as part of the spallation process, or by another ejection mechanism instead of, or in addition to, the spallation. Melosh (1989, Figure 5.8) presents contours of peak shock pressure and ejection velocity for the spallation model as a function of depth in units of the projectitle diameter. Ejection velocity contours are given in units of impact velocity, $\mathrm{U}$, and pressure contours in units of $\rho_{\mathrm{t}} U^{2}$. For a typical impact velocity $U=15 \mathrm{~km} / \mathrm{s}$ and target density $\rho_{\mathrm{t}}=3.3 \mathrm{~g} / \mathrm{cm}^{3}$, peak shock pressures of $15 \mathrm{GPa} \leq P_{\max } \leq 45 \mathrm{GPa}$ for Martian meteorites give $\sim 0.2 \leq\left(P_{\max } / \rho_{\mathrm{t}} U^{2}\right) \leq 0.6$, corresponding to depth to diameter ratios, $d / a$, in the range $\sim 0.1-0.3$ very near the impact site and just below the near surface interference zone. Ejection velocities lie in the range $0.2 \leq\left(V_{\mathrm{ej}} / U\right)$ $\leq 0.5$, i.e., $3.5 \mathrm{~km} / \mathrm{s} \leq V_{\text {ej }} \leq 7.5 \mathrm{~km} / \mathrm{s}$ for $U=15 \mathrm{~km} / \mathrm{s}$. Thus, for impactors $\sim 1 \mathrm{~km}$ in diameter, the depth of origin of the Martian meteorites is implied to be $\sim 100-300 \mathrm{~m}$. Such impactors would produce final craters $\sim 13 \mathrm{~km}$ in diameter (Mileikowsky et al., 2000).

One apparent discrepancy between the predictions of this model and observations of the Martian meteorites concerns the apparent absence of lightly shocked Martian meteorites from our collections. According to the model (e.g., Melosh, 1989, Equation 6.4.3), the mass $m_{\mathrm{ej}}$ of material ejected at velocities greater than $V_{\text {ej }}$ and shocked to pressures less than $P_{\max }$ is

$$
m_{\mathrm{ej}} / m=1.2\left(P_{\max } / \rho_{\mathrm{t}} c_{\mathrm{L}} U\right)\left[1-\left(2 V_{\mathrm{ej}} / U\right)^{1 / 3}\right]
$$

where $m$ is the projectile mass, and $c_{\mathrm{L}}$ is the seismic wave velocity of the target. The other quantities are as previously defined. For $q=6 \mathrm{~km} / \mathrm{s}, P_{\max }=$ $15 \mathrm{GPa}$, and other quantities as above, this equation predicts $m_{\mathrm{ej}} / m=0.08$. Likewise, $m_{\mathrm{ej}} / m=0.23$ is predicted for $P_{\max }=45 \mathrm{GPa}$. Thus, we would expect that approximately $1 / 3$ of the meteorites would have been shocked to pressures $<15 \mathrm{GPa}$, whereas none are observed. The seriousness of this discrepancy is unclear because the number of recovered meteorites may be too few to give reliable 
statistics. Indeed, agreement between observation and theory is significantly improved if the lower value of $P_{\max }$ is shifted to $\sim 20 \mathrm{GPa}$, so that the nakhlites populate a low-shock bin. In this case, the observed ratio of "low-shock" to "highshock" meteorites becomes 1: 6 in comparison to the predicted value of 1: 2.3. Nevertheless, the apparent lack of lightly shocked Martian meteorites is puzzling.

Because the functional relation between $P_{\mathrm{cw}}$ and particle velocity $V_{\mathrm{p}}$ varies with composition, there could be a compositional bias in the material ejected. Also, because both maximum pressure and particle velocity in the compressive wave decrease approximately as the inverse square of the distance from the impact (Equation 2; Melosh, 1985, Figure 1), and the area of an annulus of interference increases with the square of the distance, the majority of the material ejected will be near the largest value of $r$ and the smallest value of $V_{p}$ consistent with acceleration to escape velocity. This effect may lead to relatively long delays between arrival of the compression and rarefaction waves, and, thus, to relatively high values of $P_{\text {res }}$ for the Martian meteorites.

Strong coupling of compressive shock into ejected Martian meteorites implies that they come from very near the surface contour of the spall zone. The most likely place of origin of the meteorites is from within the zone of "Grady-Kipp fragments" lying just below the spall zone illustrated in Figure 11 of Melosh (1984). The locus of the spall contour is given by $z_{\mathrm{p}}$ in Equation (3) of Melosh (1985). Warren (1994) estimates the ratio of $z_{\mathrm{p}}$ to projectile radius $r_{\mathrm{p}}$ as $z_{\mathrm{p}} / r_{\mathrm{p}} \sim 0.2-0.4$, and $z_{\mathrm{p}} \sim 50-100 \mathrm{~m}$ for a $\sim 10 \mathrm{~km}$ diameter crater produced by an impactor of radius $r_{\mathrm{p}} \sim 250 \mathrm{~m}$. These depths are consistent with those estimated above by comparing meteorite shock pressures to the predicted shock contours of Melosh (1989), and allow excavation of the basaltic shergottites and possibly even the nakhlites from their places of igneous crystallization. The textures of the lherzolitic shergottites show that they crystallized in a large volume (Harvey et al., 1993), and thus at greater depths, and suggests they were relocated to the place where they were ejected. Because coherent, homogeneous material is required for build-up of maximal pressure gradients, highly brecciated material from the Martian highlands probably is discriminated against in the launch process. Thus, ALH84001, although previously shocked, probably was part of a larger coherent block prior to its ejection from Mars, and not part of the Martian regolith.

\section{Concluding Remarks}

Further study of the shock metamorphic histories of the Martian meteorites, combined with an improved quantitative understanding of the ejection mechanism(s), can make an important contribution to determining launch conditions and prelaunch sample locations. As additional meteorites are discovered, it will be particularly important to establish whether the "launch window" of peak shock pressures is maintained. Head and Melosh (2000) conclude that most Martian meteorites 
come from relatively small events of crater diameter $\sim 3 \mathrm{~km}$, just large enough to eject candidate Martian meteorite material. Nevertheless, several characteristics of the meteorites, including a relatively high percentage of "large" meteorites, strong launch pairing, sampling of a limited number of events, pre-launch shielding from cosmic rays, and, possibly, secondary break-ups in space, favor larger events. Warren (1994) noted that in the context of the spallation model, Nakhla and Zagami, representatives of two main ejection groups of Martian meterorites, probabably came from craters $\sim 15 \mathrm{~km}$ and $\sim 11 \mathrm{~km}$ in diameter, respectively. The launch mechanism for the Martian meteorites is sufficiently uncertain that a number of possible mechanisms should continue to be evaluated, however.

Because the places of origin of the Martian meteorites are unknown, use of their ages for calibrating the cratering rate is distinctly limited. Nevertheless, the observation of young igneous crystallization ages among the meteorites, down to $\sim 165 \mathrm{Myr}$, shows that Martian volcanism continues essentially until the present day. Moreover, the observation of a high proportion of young ages suggests that Mars has been volcanically relatively active at recent times. The grouping of Martian meteorite ages around certain preferred values emphasizes the need to correct for "launch-pairing" among them, in contrast to the lunar case, where most individual meteorites appear to represent individual ejection events (Warren, 1994). We note that efforts to determine reliable launch-pairing of the meteorites will enable better interpretation of a variety of mineralogical, geochemical, and isotope geochemical data obtained for these rocks, currently our only samples of Mars. Finally, it must be noted that the degree of reliability currently achieved for radiometric dating of the Martian samples results from two decades of experience and improvements in laboratory techniques. Not all of the problems encountered in dating these samples have been analytical. Martian rocks appear to bear the record of a complex series of igneous and secondary processes, and the return of Martian samples to terrestrial laboratories will be required to answer the many remaining questions of Martian chronology. Those samples, too, will doubtless hold surprises for unwary analysts, but, if adequate samples are returned, dating them absolutely should be possible.

\section{Acknowledgements}

We thank the International Space Science Institute for hosting the Workshop on the Evolution of Mars, held at Bern, Switzerland, 10-14 April, 2000, and especially Johannes Geiss and Reinald Kallenbach for its organization. W. Hartmann and an anonymous reviewer tactfully prodded us into making this a more easily readable and comprehensive contribution. Technical support was provided by D. Garrison, H. Wiesmann, and Y. Reese (Lockheed-Martin, Houston), and A. Chaoui (Physikalisches Institut, Bern). Financial support by NASA's Cosmochemistry Program, RTOP 344-31-30, to L. Nyquist, D. Bogard, C.-Y. Shih; the Swiss 
National Science Foundation to O. Eugster; and the Deutsche Forschungsgemeinschaft (DFG) to A. Greshake and D. Stöffler is gratefully acknowledged.

\section{References}

Barlow, N.G.: 1997, 'The Search for Possible Craters for Martian Meteorite ALH84001', Proc. 28th Lunar Planet. Sci. Conf., 65-66.

Becker, R.H., and Pepin, R.O.: 1984, 'The Case for a Martian Origin of the Shergottites: Nitrogen and Noble Gases in EET 79001', Earth Planet. Sci. Lett. 69, 225-242.

Becker, R.H., and Pepin, R.O.: 1986, 'Nitrogen and Light Noble Gases in Shergotty', Geochim. Cosmochim. Acta 50, 993-1000.

Becker, R.H., and Pepin, R.O.: 1993, 'Nitrogen and Noble Gases in a Glass Sample from the LEW88516 Shergottite', Meteoritics 28, 637-640.

Becker, L., Glavin, D.P., and Bada, J.L.: 1997, 'Polycyclic Aromatic Hydrocarbons (PAHs) in Antarctic Martian Meteorites, Carbonaceous Chondrites, and Polar Ice', Geochim. Cosmochim. Acta 61, 475-481.

Berkley, J.L., and Keil, K.: 1981, 'Olivine Orientation in the ALHA77005 Achondrite', Am. Mineral. 66, 1233-1236.

Berkley, J.L., and Boynton, N.J.: 1992, 'Minor/major Element Variation Within and Among Diogenite and Howardite Orthopyroxenite Groups', Meteoritics 27, 387-394.

Binns R.W.: 1967, 'Stony Meteorites Bearing Maskelynite', Nature 214, 1111-1112.

Bischoff, A., and Stöffler, D.: 1992, 'Shock Metamorphism as a Fundamental Process in the Evolution of Planetary Bodies: Information from Meteorites', Eur. J. Minerals 4, 707-755.

Bell, J.F. III, McSween, H.Y., Jr., Crisp, J.A., Morris, R.V., Murchie, S.L., Bridges, N.T., Johnson, J.R., Britt, D.T., Golombek, M.P., Moore, H.J., Ghosh, A., Bishop, J.L., Anderson, R.C., Brückner, J., Economou, T., Greenwood, J.P., Gunnlaugsson, H.P., Hargraves, R.M., Hviid, S., Knudsen, J.M., Madsen, M.B., Reid, R., Rieder, R., and Soderblom, L.: 2000, 'Mineralogic and Compositional Properties of Martian Soil and Dust: Results from Mars Pathfinder', J. Geophys. Res. 105, 1721-1755.

Blichert-Toft, J., Gleason J.D., Telouk, P., and Albarède, F.: 1999, 'The Lu-Hf Isotope Geochemistry of Shergottites and the Evolution of the Martian Mantle-crust System', Earth Plan. Sci. Lett. 173, 25-39.

Boctor, N.Z., Fei, Y., Bertka, C.M., O’D Alexander, C.M., and Hauri, E.: 1998, 'Vitrification and High Pressure Phase Transition in Olivine Megacrysts from Lithology A in Martian Meteorite EETA79001', Proc. 29th Lunar Planet. Sci. Conf., abstract \#1492.

Bogard, D.D.: 1995, 'Impact Ages of Meteorites: A Synthesis', Meteoritics 30, 244-268.

Bogard, D.D., and Husain, L.: 1977, 'A new 1.3 Aeon-young Achondrite', Geophys. Res. Lett. 4, 69-71.

Bogard, D.D., and Johnson, P.: 1983, 'Martian Gases in an Antarctic Meteorite?', Science 221, 651654.

Bogard, D.D., and Garrison, D.H.: 1998, 'Relative Abundances of Argon, Krypton, and Xenon in the Martian Atmosphere as Measured in Martian Meteorites', Geochim. Cosmochim. Acta 62, $1829-1835$.

Bogard, D.D., and Garrison, D.H.: 1999, 'Argon-39-argon-40 "Ages” and Trapped Argon in Martian Shergottites, Chassigny, and Allan Hills 84001', Met. Planet. Sci. 34, 451-473.

Bogard, D.D., Husain, L., Nyquist, L.E.: 1979, ${ }^{400} \mathrm{Ar}-{ }^{39} \mathrm{Ar}$ Age of the Shergotty Achondrite and Implications for its Post-shock Thermal History', Geochim. Cosmochim. Acta 43, 1047-1056. 
Bogard, D.D., Nyquist, L.E., and Johnson, P.: 1984, 'Noble Gas Contents of Shergottites and Implications for the Martian Origin of SNC Meteorites', Geochim. Cosmochim. Acta 48, 1723-1739.

Bogard, D.D., Hörz, F., and Johnson, P.: 1986, 'Shock-implanted Noble Gases: An Experimental Study with Implications for the Origin of Martian Gases in Shergottite Meteorites', Proc. 17th Lunar Planet. Sci. Conf., J. Geophys Res. 91, E99-E114.

Borg, L.E., Nyquist, L.E., Taylor, L.A., Wiesmann, H., Shih, C.-Y.: 1997, 'Constraints on Martian Differentiation Processes from $\mathrm{Rb}-\mathrm{Sr}$ and $\mathrm{Sm}-\mathrm{Nd}$ Isotopic Analyses of the Basaltic Shergottite QUE 94201', Geochim. Cosmochim. Acta 61, 4915-4931.

Borg, L.E., Nyquist, L.E., Wiesmann, H.: 1998a, 'Rb-Sr Isotopic Systematics of the Lherzolitic Shergottite LEW88516', Proc. 29th Lunar Planet. Sci. Conf., abstract \#1233 (CD-ROM).

Borg, L.E., Nyquist, L.E., Wiesmann, H., Reese, Y.: 1998b, 'Samarium-neodymium Isotopic Systematics of the Lherzolitic Shergottite Lewis Cliff 88516' Met. Planet. Sci. 33, A20.

Borg, L.E., Connelly, J.N., Nyquist, L.E., Shih, C.-Y., Wiesmann, H., Reese, Y.: 1999, 'The Age of the Carbonates in Martian Meteorite ALH84001', Science 286, 90-94.

Borg, L.E., Nyquist, L.E., Wiesmann, H., Reese Y., Papike, J.J.: 2000, 'Sr-Nd Isotopic Systematics of Martian Meteorite DaG476', Proc. 31st Lunar Planet. Sci., abstract \#1036 (CD-ROM).

Borg, L.E., Nyquist, L.E., Reese, Y., Wiesmann, H., Shih C.Y., Taylor, L.A., and Ivanova, M.: 2001a, 'The Age of Dhofar 019 and its Relationship to the Other Martian Meteorites', Proc. 32nd Lunar Planet. Sci. Conf., abstract \#1144 (CD-ROM).

Borg, L.E., Nyquist, L.E., Wiesmann, H., and Reese, Y.: 2001b, 'Constraints on Secondary Alteration, Shock Metamorphism, and Petrogenetic Relationships of the Martian Meteorites LEW 88516 and ALHA77005 from Their Rb-Sr and Sm-Nd Isotopic Systematics', Geochim. Cosmochim. Acta, submitted.

Boston, P.J., Ivanov, M.V., and McKay, C.P.: 1992, 'On the Possibility of Chemosynthetic Ecosystems in Subsurface Habitats on Mars', Icarus 95, 300-308.

Bunch, T.E., and Reid, A.M.: 1975, 'The Nakhlites. Part I. Petrography and Mineral Chemistry', Meteoritics 10, 303-315.

Bridges, J.C., and Grady, M.M.: 2000, 'Evaporite Mineral Assemblages in the Nakhlite (Martian Meteorites)', Earth Planet. Sci. Lett. 176, 267-279.

Chen, J.H., and Wasserburg, G.J.: 1986, 'Formation Ages and Evolution of Shergotty and its Parent Planet from U-Th-Pb Systemics', Geochim. Cosmochim. Acta 50, 955-968.

Chen, J.H., and Wasserburg, G.J.: 1993, 'LEW88516 and SNC Meteorites', Proc. 24th Lunar Planet. Sci. Conf., 275-276, (abstract).

Clayton, R.N., and Mayeda T.K.: 1996, 'Oxygen Isotope Studies of Achondrites', Geochim. Cosmochim. Acta 60, 1999-2017.

Crozaz, G., and Wadhwa, M.: 1999, 'Chemical Alteration of hot Desert Meteorites: The Case of Shergottite Dar al Gani 476', in: Workshop on Extraterrestrial Materials from Cold and Hot Deserts. Kwa Maritane, Pilanesberg, South Africa, July 6-8.

Dreibus, G., Palme, H., Rammensee, W., Spettel, B., Weckwerth, G., and Wänke, H.: 1982, 'Composition of the Shergotty Parent Body: Further Evidence of a two Component Model for Planet Formation', Proc. 13th Lunar Planet. Sci. Conf., 186-187.

Dreibus, G., and Wänke, H.: 1987, 'Volatiles on Earth and Mars: A Comparison', Icarus 71, 225-240.

Dreibus, G., Burghele, A., Jochum, K.P., Spettel, B., Wlotzka, F., and Wänke, H.: 1994, 'Chemical and Mineral Composition of ALH84001: A Martian Orthopyroxenite', Meteoritics 29, 461.

Dreibus, G., Spettel, B., Wlotzka, F., Schultz, L., Weber, H.W., Jochum, K.P., and Wänke, H.: 1996, 'QUE94001: An Unusual Martian Basalt', Met. Planet. Sci. 31 Suppl., A39-A40 (abstract).

Duke, M.B.: 1968, 'The Shergotty Meteorite: Magmatic and Shock Metamorphic Features', in B.M. French and N.M. Short (eds.), Shock Metamorphism of Natural Materials, Mono Book Corp., Baltimore, pp. 613-621.

Eberhardt, P., and Hess, D.C.: 1960, 'Helium in Stone Meteorites', Astrophys. J. 131, 38-46. 
El Goresy, A., Dubrovinsky, L., Sharp, T.G., Saxena, S.K., and Chen, M.: 2000, 'A Monoclinic Post-shishovite Polymorph of Silica in the Shergotty Meteorite', Science 288, 1632-1634.

Engelhardt, W., von, and Graup, G.: 1984, 'Suevite of the Ries Crater, Germany: Source Rocks and Implications for Cratering Mechanics', Geol. Rundschau 73, 447-481.

Eugster, O.: 1994, 'Orthopyroxenite ALH84001: Ejection from Mars (?) 15 Ma Ago', Meteoritics 29, 464 (abstract).

Eugster, O., and Michel, T.: 1995, 'Common Asteroid Break-up Events of Eucrites, Diogenites, and Howardites and Cosmic-ray Production Rates for Noble Gases in Achondrites', Geochim. Cosmochim. Acta 59, 177-199.

Eugster, O., Eberhardt, P., and Geiss, J.: 1967, ${ }^{8}{ }^{81} \mathrm{Kr}$ in Meteorites and ${ }^{81} \mathrm{Kr}$ Radiation Ages', Earth Planet. Sci. Lett. 2, 77-82.

Eugster, O., Polnau, E., and Terribilini, D.: 1997a, 'Ejection Age of Martian Lherzolite Yamato 793605, Chassigny, and Shergotty and Formation Age of Shergotty Maskelynite', Met. Planet Sci. 32, A40.

Eugster, O., Weigel, A., and Polnau, E.: 1997b, 'Ejection Times of Martian Meteorites', Geochim. Cosmochim. Acta. 61, 2749-2757.

Evans, J.C., Wacker, J., and Reeves, J.H.: 1992, 'Terrestrial Ages of Victoria Land Meteorites Collected by the United States Expeditions 1985-1987', in Marvin and Mc Pherson (eds.), Smithson. Contrib. Earth Sci. 30, Washington DC, 45-56.

Floran, R.J., Prinz, M., Hlava P.F., Keil, K., Nehru C.E., and Hinthorne, J.R.: 1978, 'The Chassigny Meteorite: A Cumulate Dunite with Hydrous Amphibole-bearing Melt Inclusions', Geochim. Cosmochim. Acta 42, 1213-1229.

Folco, L., Franchi, I.A., Scherer, P., Schultz, L., and Pillinger, C.T.: 1999, 'Dar al Gani 489 Basaltic Shergottite: A new Find from the Sahara Likely Paired with Dar al Gani 476', Meteorit.Planet. Sci. 34 (Suppl.), A36-A37 (abstract).

Gale, N.H., Arden. J.W., Hutchison. R.: 1975, 'The Chronology of the Nakhla Achondritic Meteorite', Earth Planet. Sci. Lett. 26, 195-206.

Ganapathy, R., and Anders, E.: 1969, 'Ages of Calcium-rich Achondrites - II. Howardites, Nakhlites, and the Angra dos Reis Angrite', Geochim. Cosmochim. Acta 33, 775-787.

Garrison, D.H., and Bogard, D.D.: 1998, 'Isotopic Composition of Trapped and Cosmogenic Noble Gases in Several Martian Meteorites', Met. Planet. Sci. 33, 721-736.

Garrison, D.H., and Bogard, D.D.: 2000, 'Cosmogenic and Trapped Noble Gases in the Los Angeles Martian Meteorite', 63rd Annual Met. Soc. Mtg. Aug. 28-Sept. 1, 2000, Chicago, (abstract).

Geiss, J., and Hess, D.C.: 1958, 'Argon-potassium Ages and the Isotopic Composition of Argon from Meteorites', Astrophys. J. 127, 224-236.

Gladman, B.: 1997, 'Destination: Earth. Martian Meteorite Delivery', Icarus 130, 228-246.

Gleason, J.D., Kring, D.A., Hill, D.H., and Boynton, W.V.: 1997, 'Petrography and Bulk Chemistry of Martian Orthopyroxenite ALH84001: Implications for the Origin of Secondary Carbonates', Geochim. Cosmochim. Acta 61, 3503-3512.

Golden, D.C., Ming, D.W., Schwandt, C.S., Lauer, H.V., Socki, R.A., Morris, R.V., Lofgren, G.E., and McKay, G.: 2000a, 'Inorganic Formation of Zoned Mg-Fe-Ca Carbonate Globules with Magnetite and Sulfide Rims Similar to those in Martian Meteorite ALH84001', Proc. 31 st Lunar Planet. Sci. Conf., LPI, Houston, abstract \#1799 (CD-ROM).

Golden, D.C., Ming, D.W., Schwandt, C.S., Morris, R.V., Yang S.V., and Lofgren, G.E.: 2000b, ‘An Experimental Study on Kinetically-driven Precipitation of Calcium-magnesium-iron Carbonates from Solution: Implications for the Low-temperature Formation of Carbonates in Martian Allan Hills 84001', Met. Planet. Sci. 35, 457-465.

Gooding, J.L., Wentworth, S.J., and Zolensky, M.E.: 1991, 'Aqueous Alteration of the Nakhla Meteorite', Meteoritics 26, 135-143.

Greshake, A.: 1998, 'Transmission Electron Microscope Charactrization of Shock Defects in Minerals from the Nakhla SNC Meteorite', Meteorit. Planet. Sci. 33, A63. 
Greshake, A., and Stöffler, D.: 1999, 'Shock Metamorphic Features in the SNC Meteorite Dar al Gani 476', Proc. 30th Lunar Planet. Sci., LPI, Houston abstract \#1377 (CD-ROM).

Greshake, A., and Stöffler, D.: 2000, 'Shock Related Melting Phenomena in the SNC Meteorite Dar al Gani 476', Proc. 31 st Lunar Planet. Sci. Conf., LPI, Houston abstract \#1043 (CD-ROM).

Greshake, A., Stephan, T., and Rost, D.: 1998, 'Symplectic Exsolutions in Olivine from the Martian Meteorite Chassigny: Evidence for Slow Cooling Under Highly Oxidizing Conditions', Proc. 29th Lunar Planet. Sci. Conf., abstract \#1069.

Greshake, A., Schmitt, R.T., Stöffler, D., Pätsch, M., and Schultz, L.: 2001, 'Dhofar 081: A new Lunar Highland Meteorite', Meteoritics and Planet. Sci., in press.

Grossman, J.N.: 2000, The Meteoritical Bulletin, No. 84, Meteorit. Planet. Sci. 35, A199-A225.

Harper, C.L., Jr., Nyquist, L.E., Bansal, B.M., Wiesmann, H., and Shih, C.-Y.: 1995, 'Rapid Accretion and Early Differentiation of Mars Indicated by ${ }^{142} \mathrm{Nd} /{ }^{144} \mathrm{Nd}$ in SNC Meteorites', Science 267, 213-216.

Hartmann, W.K.: 1999, 'Martian Cratering VI: Crater Count Isochrons and Evidence for Recent Volcanis from Mars Global Surveyor', Met. Planet. Sci. 34, 167-177.

Hartmann, W.K.: 2001, 'Martian Seeps and Their Relation to Youthful Geothermal Activity', Space Sci. Rev., this volume.

Hartmann, W.K., and Berman, D.C.: 2000, 'Elysium Planitia Lava Flows: Crater Count Chronology and Geological Implications', J. Geophys. Res. 105, 15,011-15,025.

Hartmann, W.K., and Neukum, G.: 2001, 'Cratering Chronology and Evolution of Mars', Space Sci. Rev., this volume.

Hartmann, W.K., Anguita, J., de la Casa, M., Berman, D.C., and Ryan, E.V.: 2000, 'Martian Cratering 7: The Role of Impact Gardening', Icarus 148, in press.

Harvey, R., and McSween, H.Y., Jr.: 1996, 'A Possible High-temperature Origin for the Carbonates in the Martian Meteorite ALH84001', Nature 382, 49-51.

Harvey, R.P., Wadhwa, M., McSween, H.Y., Jr., and Crozaz, G.: 1993, 'Petrography, Mineral Chemistry and Petrogenesis of Antarctic Shergottite LEW88516', Geochim. Cosmochim. Acta 57, $4769-4783$.

Head, J.N., Melosh, H.J.: 2000, 'Launch Velocity Distribution of the Martian Clan Meteorites', Proc. 31st Lunar Planet. Sci., LPI, Houston, abstract \#1937 (CD-ROM).

Heymann, D., Mazor, E., and Anders, E.: 1968, 'Ages of Ca-rich achondrites - I. Eucrites', Geochim. Cosmochim. Acta 32, 1241-1268.

Ikeda, Y.: 1994, 'Petrography and Petrology of the ALH-77005 Shergottite', Proc. NIPR Symp. Antarct. Meteorites 7, 9-29.

Ilg, S., Jessberger, E.K., El Goresy, A.: 1997, 'Argon-40/argon-39 Laser Extraction Dating of Individual Maskelynites in SNC Pyroxenite Allan Hills 84001', Met. and Planet. Sci. 32, A65.

Ivanov, B.: 2001, 'Mars/Moon Cratering Rate Ratio Estimates', Space Sci. Rev., this volume.

Jagoutz, E.: 1989, 'Sr and Nd Isotopic Systematics in ALHA77005: Age of Shock Metamorphism in Shergottites and Magmatic Differentiation on Mars', Geochim. Cosmochim. Acta 53, 2429-2441.

Jagoutz, E.: 1996, 'Nd Isotopic Systematics of Chassigny', Proc. 27th Lunar Planet. Sci., 597-598 (abstract).

Jagoutz, E., and Wänke H.: 1986, 'Sr and Nd Isotopic Systematics of Shergotty Meteorite', Geochim. Cosmochim. Acta 50, 939-953.

Jagoutz, E., and Jotter, R.: 1999, 'SNC Meteorites: Relatives Finally Finding Each Other', Met. Planet. Sci. 34, A59.

Jagoutz, E., and Jotter, R.: 2000, 'New Sm-Nd Isotope Data on Nakhla Minerals', Proc. 31 st Lunar Planet. Sci., abstract \#1609 (CD-ROM).

Jagoutz, E., Sorowka, A., Vogel, J.D., Wänke, H.: 1994, 'ALH84001: Alien or Progenitor of the SNC Family?', Meteoritics 29, 478-479 (abstract).

Jagoutz, E., Bogdanovski, O., Krestina, N., Jotter, R.,: 1999, 'DAG: A new age in the SNC Family, or the First Gathering of Relatives', Proc. 30th Lunar Planet. Sci., abstract \#1808 (CD-ROM). 
Jones, J.H.: 1986, 'A Discussion of Isotopic Systematics and Mineral Zoning in the Shergottites: Evidence for a 180 Myr Igneous Crystallization Age', Geochim. Cosmochim. Acta 50, 969-977.

Jones, J.H.: 1989, 'Isotopic Relationships Among the Shergottites, Nakhlites, and Chassigny', Proc. 19th Lunar Planet. Sci. Conf. , 465-474.

Jull, A.J.T., and Donahue, D.J.: 1988, 'Terrestrial ${ }^{14}$ C Age of the Antarctic Shergottite EETA79001', Geochim. Cosmochim. Acta 52, 1309-1311.

Jull, A.J.T., Cielaszyk, E., Brown, S.T., and Donahue, D.J.: 1994, ${ }^{14}$ C Terrestrial Ages of Achondrites from Victoria Land Antarctica', Proc. 25th Lun. Planet. Sci., 647-648.

Jull, A.J.T., Eastoe, C.J., Xue, S., and Herzog, G.F.: 1995, 'Isotopic Composition of Carbonate in the SNC Meteorites ALH84001 and Nakhla', Meteoritics 30, 311-318.

Jull, A.J.T., Eastoe, C.J., and Clout, S.: 1997, 'Terrestrial Age of the Lafayette Meteorite and Stableisotopic Composition of Weathering Products', Proc. 28th Lun. Planet. Sci., 685-686.

Jull, A.J.T., Courtney, C., Jeffrey, D.A., and Beck, J.W.: 1998, 'Isotopic Evidence for a Terrestrial Source of Organic Compounds Found in Martian Meteorites Allan Hills 84001 and Elephant Moraine 79001', Science 279, 366-369.

Kadano, T., and Fugiwara, A.: 1996, 'Observation of Expanding Vapor Cloud Generated by Hypervelocity Impact', J. Geophys. Res. 101, 26,097-26,109.

Keller, L.P., Treiman A.H., and Wentworth S.J.: 1992, 'Shock Effects in the Shergottite LEW88516: Optical and Electron Microscope Observations', Meteoritics 27, 242.

Keszthelyi, L., McEwen, A.S., and Thordarson, T.;, 2000, 'Terrestrial Analogs and Thermal Models for Martian Flood Lavas', J. Geophys. Res. 105, 15,027-15,049.

Kieffer, S.W., Schaal, R., Gibbons, R., Hörz, F., Milton, D., and Duba, A.: 1976, 'Shocked Basalt from Lonar Crater, India, and Experimental Analogues', Proc. 7th Lunar Planet. Sci. Conf., 1391-1412.

Knott, S.F., Ash, R.D., and Turner, G: 1996, ${ }^{40} \mathrm{Ar}-{ }^{39}$ Ar Dating of ALH84001: Evidence for the Early Bombardment of Mars', Proc. 26th Lunar Planet. Sci. Conf., 765-766 (abstract).

Kring, D.A., and Gleason, J.D.: 1997, 'Magmatic Temperatures and Compositions on Early Mars as Inferred from the Orthopyroxene-silica Assemblage in Allan Hills 84001', Meteoritics 32, A74.

Kring, D.A., Swindle, T.D., Gleason, J.D., and Grier, J.A.: 1998, 'Formation and Relative Ages of Maskelynite and Carbonate in ALH84001', Geochim. Cosmochim. Acta 62, 2155-2166.

Lambert, P.: 1985, 'Metamorphic Record in Shergottites', Meteoritics 20, 690-691.

Lambert, P., and Grieve, R.A.F.: 1984, 'Shock-experiments on Maskelynite-bearing Anorthosite', Earth Planet. Sci. Lett. 68, 159-171.

Lancet, M.S., and Lancet, K.: 1971, 'Cosmic-ray and Gas Retention Ages of the Chassigny Meteorite', Meteoritics 6, 81-86.

Langenhorst, F., and Greshake, A.: 1999, 'A TEM Study of Chassigny: Evidence for Strong Shock Metamorphism', Met. Planet. Sci. 34, 43-48.

Langenhorst, F., and Poirier, J.-P.: 2000, “'Eclogitic” Minerals in a Shocked Basaltic Meteorite', Earth Planet. Sci. Lett. 176, 259-265.

Langenhorst, F., Stöffler, D., and Klein, D.: 1991, 'Shock Metamorphism of the Zagami Achondrite', Proc. 22nd Lunar Planet. Sci. Conf., 779-780.

Longhi, J.: 1991, 'Complex Magmatic Processes on Mars: Inferences from the SNC Meteorites', Proc. Lunar Planet. Sci. Conf. 21, 695-709.

Lodders, K.: 1998, 'A Survey of Shergottite, Nakhlite and Chassigny Meteorites Whole-rock Compositions', Met. Planet. Sci. 33, A183-A190.

Lorenzetti, S., and Eugster, O.: 2001, 'Ejection Ages of the Shergottites Los Angeles and Say al Uhaymir', to be published.

Lugmair, G.W., and Galer, S.J.: 1992, 'Age and Isotopic Relationships Among the Angrites Lewis Cliff 86010 and Angra dos Reis', Geochim. Cosmochim. Acta 56, 1673-1694.

Malin, M.C., and Edgett, K.S.: 2000, 'Evidence for Recent Groundwater Seepage and Surface Runoff on Mars', Science 288, 2330-2335. 
Marti, K.: 1967, 'Mass-spectrometric Detection of Cosmic-ray-produced Kr-81 in Meteorites and the Possibility of Kr-Kr Dating', Phys. Rev. Lett. 18, 264-266.

Marti, K., and Matthew, K. J.: 2000, 'Ancient Martian Nitrogen', Geophys. Res. Lett. 27, 1463-1466.

Marti, K., Kim, J.S., Thakur, A.N., McCoy, T.J., and Keil, K.: 1995, 'Signatures of the Martian Atmosphere in Glass of the Zagami Meteorite', Science 267, 1981-1984.

McCoy, T.J., Taylor, G.J., and Keil, K.: 1992, 'Zagami: Product of a Two-stage Magmatic History', Geochim. Cosmochim. Acta 56, 3571-3582.

McKay, D.S., Gibson, E.K., Jr., Thomas-Keprta, K.L., Vali, H., Romanek, C.S., Clemett, S.J., Chillier, X.D.F., Maechling, C.R., and Zare, R.N.: 1996, 'Search for Life on Mars: Possible Relic Biogenic Activity in Martian Meteorite ALH84001', Science 273, 924-930.

McSween, H.Y., Jr.: 1994, 'What Have we Learned about Mars from SCN Meteorites', Meteoritics 29, 757-779.

McSween, H.Y., Jr., and Stöffler, D.: 1980, 'Shock Metamorphic Features in ALHA77005 Meteorite', Proc. 11th Lunar Planet. Sci. Conf., 717-719.

McSween, H.Y., Jr., and Harvey, R.P.: 1998, 'An Evaporation Model for Formation of Carbonates in the ALH84001 Martian Meteorite', Intern. Geol. Rev. 40, 774-783.

McSween, H.Y., Jr., and Keil, K.: 2000, 'Mixing Relationships in the Martian Regolith and the Composition of Globally Homogeneous Dust', Geochim. Cosmochim. Acta 64, 2155-2166.

Melosh, H.J.: 1984, 'Impact Ejection, Spallation, and the Origin of Meteorites', Icarus 59, 234-260.

Melosh, H.J.: 1985, 'Ejection of Rock Fragments from Planetary Bodies', Geology 13, 144-148.

Melosh, H.J.: 1989, 'Impact Cratering: A Geologic Process', Sky and Telescope 78, 382.

Melosh, H.J.: 1995, 'Cratering Dynamics and the Delivery of Meteorites to the Earth', Meteoritics 30, 545-546.

Metzler, K., Bobe, K.D., Palme, H., Spettel, B. and Stöffler, D.: 1995, 'Thermal and Impact Metamorphism of the HED-asteroid', Planet. Space Sci. 43, 499-525.

Meyer, C.: 1998, Mars Meteorite Compendium - 1998, NASA, Houston, Texas, 237 pp.

Mikouchi, T., and Miyamoto, M.: 1997, 'Yamato-793605: A new Lherzolitic Shergottite from the Japanese Antarctic Meteorite Collection', Antarct. Meteorite Res. 10, 41-60.

Mikouchi, T., and Miyamoto, M.: 1998, 'Pyroxene and Olivine Microstructures in Nakhlite Martian Meteorites: Implication for Their Thermal History', Proc. 29th Lunar Planet. Sci., abstract $\# 1574$.

Mileikowsky, C., Cucinotta, F.A., Wilson, J.W., Gladman, B., Horneck, G., Lindegren, L., Melosh, J., Rickman, H., Valtonen, M., and Zheng, J.Q.: 2000, 'Natural Transfer of Viable Microbes in Space', Icarus 145, 391-427.

Minster, J.-F., Birck, J.-L., Allègre, C.-J.: 1982, 'Absolute Age of Formation of Chondrites by the ${ }^{87} \mathrm{Sr}-{ }^{87} \mathrm{Sr}$ Method', Nature 300, 414-419.

Misawa, K., Nakamura, N., Premo, W.R., Tatsumoto, M.: 1997, 'U-Th-Pb Isotopic Systematics of Lherzolitic Shergottite Yamato 793605', Antarctic Meteorites XXII, NIPR, 115-117.

Mittlefehldt, D.W.: 1994, 'ALH84001, A Cumulate Orthopyroxenite Member of the Martian Meteorite Clan', Meteoritics 29, 214-221.

Mittlefehldt, D.W., Lindstrom, D.J., Lindstrom, M.M., and Martinez, R.R.: 1997, 'Lithology A in EETA79001 - Product of Impact Melting on Mars', Proc. 28th Lunar Planet. Sci. Conf., 961962.

Miura, Y.N., Nagao, K., Sugiura, N., Sagawa, H., and Matsubara, K.: 1995, 'Orthopyroxenite ALHA84001 and Shergottite ALHA77005: Additional Evidence for a Martian Origin from Noble Gases', Geochim. Cosmochim. Acta 59, 2105-2113.

Mouginis-Mark, P.J., McCoy, T.J., Taylor, G.J., Keil, K.: 1992, 'Martian Parent Craters for the SNC Meteorites', J. Geophys. Res. 97, 10,213-10,225.

Müller, W.F.: 1993, 'Thermal and Deformational History of the Shergotty Meteorite Deduced from Clinopyroxene Microstructure', Geochim. Cosmochim. Acta 57, 4311-4322. 
Müller, H.W., and Zähringer, J.: 1969, 'Rare Gases in Stony Meteorites', in P.M. Millmann (ed.) Meteorite Research, D. Reidel, Dordrecht, pp. 845-856.

Nagao, K., Nakamura, T., Miura, Y., and Takaoka, N.: 1997, 'Noble Gases and Mineralogy of Primary Igneous Materials of the Yamato-793605 Shergottite', Natl Inst. Polar Res., Tokyo, Anarct. Meteorit. Res. 10, 125-142.

Nakamura, N., Komi, H., and Kagami, H.: 1982a, 'Rb-Sr Isotopic and REE Abundances in the Chassigny Meteorite', Meteoritics 17, 257-258.

Nakamura, N., Unruh, D.M., Tatsumoto, M., and Hutchison, R.: 1982b, 'Origin and Evolution of the Nakhla Meteorite Inferred from the Sm-Nd and U-Pb Systematics and REE, Ba, Sr, Rb Abundances', Geochim. Cosmochim. Acta 46, 1555-1573.

Neukum, G., Ivanov, B., and Hartmann, W.K.: 2001, 'Cratering Records in the Inner Solar System in Relation to the Lunar Reference System', Space Sci. Rev., this volume.

Newsom, H.E., Brittelle, G.E., Hibbitts, C.A., Crossey, L.J., and Kudo, A.M.: 1996, 'Impact Crater Lakes on Mars', J. Geophys. Res. 101, 14,951-14,955.

Nishiizumi, K., and Caffee, W.: 1996, 'Exposure History of Shergottite Queen Alexandra Range 94201', Proc. 27th Lun. Planet. Sci. Conf., 961-962.

Nishiizumi, K., and Caffee, M.W.: 1997, 'Exposure History of Shergottite Yamato' - 793605 (abstract). Antarctic Meteorites XXII, Natl Inst. Polar Res., Tokyo, 149-151.

Nishiizumi, K., Klein, J., Middleton, R., Elmore, D., Kubik, P.W., and Arnold, J.R.: 1986, 'Exposure History of Shergottites', Geochim. Cosmochim. Acta 50, 1017-1021.

Nishiizumi, K., Arnold J.R., Caffee, M.W., Finkel, R.C., and Southon, J.: 1992, 'Exposure Histories of Calcalong Creek and LEW88516 Meteorites', Meteoritics 27, 270 (abstract).

Nishiizumi, K., Masarik, J., Welten, K.C., Caffee, M.W., Jull A.J.T., and Klandrud, S.E.: 1999, 'Exposure History of new Martian Meteorite Dar al Gani 476', Proc. 30th Lun. Planet. Sci. Conf., abstract \#1966 (CD-ROM).

Nishiizumi, M.W., and Masarik, J.: 2000, 'Cosmogenic Radionuclides in Los Angeles Martian Meteorite', 63rd Annual Met. Soc. Mtg. Aug. 28-Sept. 1, 2000, Chicago (abstract).

Norman, M.D.: 1999, 'The Composition and Thickness of the Crust of Mars Estimated from Rare Earth Elements and Neodymium-isotopic Compositions of Martian Meteorites', Met. Planet. Sci. 34, 439-449.

Nyquist, L.E.: 1983, 'Do Oblique Impacts Produce Martian Meteorites?' Proc. 13th Lunar Planet. Sci. Conf., J. Geophys. Res. 88 Suppl., A785-A798.

Nyquist, L.E., Wooden, J., Bansal, B., Wiesmann, H., McKay, G., Bogard, D.D.: 1979a, 'Rb-Sr age of the Shergotty Achondrite and Implications for Metamorphic Resetting of Isochron Ages', Geochim. Cosmochim. Acta 43, 1057-1074.

Nyquist, L.E., Bogard, D.D., Wooden, J.L., Wiesmann, H., Shih, C.-Y., Bansal, B.M., and McKay, G.: 1979b, 'Early Differentiation, Late Magmatism, and Recent Bombardment on the Shergottite Parent Planet', Meteoritics 14, 502.

Nyquist, L.E., Wiesmann, H., Shih, C.-Y., Bansal, B.M.: 1986, 'Sr Isotopic Systematics of EETA79001', Proc. 17th Lunar Planet. Sci. Conf., 624-625 (abstract).

Nyquist, L.E., Bansal, B., Wiesmann, H., Shih, C.-Y.: 1994, 'Neodymium, Strontium and Chromium Isotopic Studies of the LEW86010 and Angra dos Reis Meteorites and the Chronology of the Angrite Parent Body', Meteoritics 29, 882-885.

Nyquist, L.E., Bansal, B.M., Wiesmann, H., Shih, C.-Y.: 1995, “'Martians” Young and old: Zagami and ALH84001', Proc. 26th Lunar Planet. Sci. Conf., 1065-1066 (abstract).

Nyquist, L.E., Borg, L.E., Shih, C.-Y.: 1998, 'The Shergottite Age Paradox and the Relative Probabilities for Martian Meteorites of Differing Ages', J. Geophys. Res. 103, 31,445-31,455.

Nyquist, L.E., Reese, Y.D., Wiesmann, H., Shih, C.-Y., and Schwandt, C.: 2000, 'RubidiumStrontium Age of the Los Angeles Shergottite', Met. Planet. Sci. 35, A121-A122.

Nyquist, L.E., Reese, Y., Wiesmann, H., and Shih, C.-Y.: 2001, 'Age of EET79001B and Implications for Shergottite Origins', Proc. 32nd Lunar Planet. Sci. Conf., abstract \#1407 (CD-ROM). 
O’Keefe, J.D., and Ahrens, T.J.: 1986, 'Oblique Impact: A Process for Obtaining Meteorite Samples from Other Planets', Science 234, 346-349.

Ostertag, R., Amthauer, G., Rager, H., and McSween, H.Y., Jr.: 1984, ' $\mathrm{Fe}^{3+}$ in Shocked Olivine Crystals of the ALHA77005 Meteorite', Earth Planet. Sci. Lett. 67, 162-166.

Ott, U.: 1988, 'Noble Gases in SNC Meteorites Shergotty, Nakhla, Chassigny', Geochim. Cosmochim. Acta 52, 1937-1948.

Ott, U., and Löhr, H.P.: 1992, 'Noble Gases in the new Shergottite LEW88516', Meteoritics 27, 271 (abstract).

Paetsch, M., Altmaier, M., Herpers, U., Kosuch, H., Michel, R., and Schultz, L.: 2000, 'Exposure Age of the New SNC Meteorite Sayh al Uhaymir 005', Met. Planet. Sci. 35, A124-A125 (abstract).

Pal, D.K., Tuniz, C., Moniot, R.K., Savin,W., Kruse, T., and Herzog, G.F.: 1986, 'Beryllium-10 Contents of Shergottites, Nakhlites and Chassigny', Geochim. Cosmochim. Acta 50, 2405-2409.

Papanastassiou, D.A., Wasserburg, G.J.: 1974, 'Evidence for Late Formation and Young Metamorphism in the Achondrite Nakhla', Geophy. Res. Lett. 1, 23-26.

Pierazzo, E., and Melosh, H.J.: 1999, 'Hydocode Modeling of Chicxulub as an Oblique Impact Event', Earth Planet. Sci. Lett. 165, 163-176.

Pierazzo, E., and Melosh, H.J.: 2000, 'Melt Production in Oblique Impacts', Icarus 145, 252-261.

Podosek, F.A.: 1973, 'Thermal History of the Nakhlites by the ${ }^{40} \mathrm{Ar}-{ }^{39}$ Ar Method', Earth Planet. Sci. Lett. 19, 135-144.

Pohl, J., Stöffler, D., Gall, H., and Ernstson, K.: 1977, ‘The Ries Impact Crater', in D.H. Roddy, R.O. Pepin, and R.B. Merrill (eds.), Impact and Explosion Cratering, Pergamon Press, New York, pp. 343-404.

Rieder, R., Economou, T., Wänke, H., Turkevich, A., Crisp, J., Brückner, J., Dreibus, G., McSween, H.Y., Jr.: 1997, 'The Chemical Composition of Martian Soil and Rocks Returned by the Mobile Alpha Proton X-ray Spectrometer: Preliminary Results from the X-ray Mode', Science 278, 1771-1774.

Rubin, A.E., Warren, P.H., Greenwood, J.P., Verish, R.S., Leshin, L.A., Hervig, R.L., Clayton, R.N., and Mayeda, T.K.: 2000, 'Los Angeles: the Most Differentiated Basaltic Martian Meteorite', Geology, submitted.

Sano, Y., Terada, K., Takeno, S., Taylor, L.A., McSween, H.Y.: 2000, 'Ion Microprobe Uraniumthorium-lead Dating of Shergotty Phosphates', Met. Planet. Sci. 35, 341-346.

Sarafin, R., Herpers, U., Signer, P., Wieler, R., Bonani, G., Hofmann, H.J., Morenzoni, E., Nessi, M., Suter, M., and Wölfli, W.: $1985,{ }^{10} \mathrm{Be},{ }^{26} \mathrm{Al},{ }^{53} \mathrm{Mn}$, and Light Noble Gases in the Antarctic Shergottite EETA79001(A)', Earth Planet. Sci. Lett. 75, 72-76.

Schaal, R.B., and Hörz, F.: 1977, 'Shock Metamorphism of Lunar and Terrestrial Basalts', Proc. 8th Lunar Planet. Sci. Conf., 1679-1729.

Schmitt, R.T.: 2000, 'Shock Experiments with the H6 Chondrite Kernouvé: Pressure Calibration of Microscopic Shock Effects', Met. Planet. Sci. 35, 545-560.

Schultz, L., and Freundel, M.: 1984, 'Terrestrial Ages of Antarctic Meteorites', Meteoritics 19, 310 (abstract).

Schultz, P.H., and DŠHondt, S.: 1996, 'Cretaceous-Tertiary (Chicxulub) Impact Angle and its Consequences', Geology 24, 963-967.

Schultz, L., and Franke, L.: 2000, 'Helium, Neon, and Argon in Meteorites, a Data Compilation', Max-Planck-Institut für Chemie, Mainz.

Scott, E.R.D.: 1999, 'Origin of Carbonate-magnetite-sulfide Assemblages in Martian Meteorite ALH84001', J. Geophys. Res. 104, 3803-3813.

Scott, E.R.D., Krot, A.N., and Yamagouchi, A.: 1998, 'Carbonates in Fractures of Martian Meteorite ALH84001: Petrologic Evidence for Impact Origin', Met. Planet. Sci. 33, 709-719.

Sharp, T.G., El Goresy, A., Wopenka, B., and Chen, M.: 1999, 'A Post-stihovite $\mathrm{SiO}_{2}$ Polymorph in the Meteorite Shergotty: Implications for Impact Events', Science 284, 1511-1513. 
Shih, C.-Y., Nyquist, L.E., Bogard, D.D., McKay, G.A., Wooden, J.L., Bansal, B.M., and Wiesmann, H.: 1982, 'Chronology and Petrogenesis of Young Achondrites, Shergotty, Zagami, and ALHA 77005: Late Magmatism on a Geologically Active Planet', Geochim. Cosmochim. Acta 46, 2323 2344.

Shih, C.-Y., Nyquist, L.E., Reese, Y., and Wiesmann, H.: 1998, 'The Chronology of the Nakhlite Lafayette: Rb-Sr and Sm-Nd Isotopic Ages', Proc. 29th Lunar Planet. Sci., abstract \#1145 (CDROM).

Shih, C.-Y., Nyquist, L.E., and Wiesmann, H.: 1999, 'Sm-Nd and Rb-Sr Systematics of Nakhlite Governador Valadares', Met. Planet. Sci. 34, 647-655.

Shukolyukov, Yu.A., Nazarov, M.A., and Schultz, L.: 2000, 'Dhofar019: A Shergottite with an Approximately 20-million-year Exposure Age', Met. Planet. Sci. 35, A (abstract).

Stauffer H.: 1962, 'On the Production Rates of Rare Gas Isotopes in Stone Meteorites', J. Geophys. Res. 67, 2023-2028.

Steele, I.M. and Smith, J.V.: 1982, 'Petrography and Mineralogy of two Basalts and Olivinepyroxene-spinel Fragments in Achondrite EETA79001', J. Geophys. Res. 87, A375-A384.

Steiger, R.H., and Jäger, E.: 1977, 'Subcommission on Geochronology: Convention on the use of Decay Constants in Geo- and Cosmochronology', Earth Planet. Sci. Lett. 36, 359-362.

Stephan, T., Rost ,D., Jessberger, E.K., and Greshake, A.: 1998, 'Polycyclic Aromatic Hydrocarbons are Everywhere in Allan Hills 84001', Met. Planet. Sci. 33, A149-A150.

Stephan, T., Greshake, A., Herpers, U., Jessberger, E.K., Jochum, K.-P., Michel, R., Ott, U., and Stöffler, D.: 1999, 'Systematic and Interdisciplinary Analyses of all SNC Meteorites', Proposal, Münster, pp. 42.

Stöffler, D.: 1972, 'Deformation and Transformation of Rock-forming Minerals by Natural and Experimental Shock Processes: I. Behavior of Minerals Under Shock Compression', Fortschr. Miner. 49, 50-113.

Stöffler, D.: 1984, 'Glasses Formed by Hypervelocity Impact', J. Non-Cryst. Sol. 67, 465-502.

Stöffler, D.: 2000, 'Maskelynite Confirmed as Diaplectic Glass: Indication for Peak Shock Pressures Below 45 GPa in all Martian Meteorites', Proc. 31st Lunar Planet. Sci., abstract \#1170.

Stöffler, D., and Ostertag, R.: 1983, 'The Ries Impact Crater', Fortschr. Miner. 61, Beiheft 2, 71-116.

Stöffler, D., Ostertag, R., Jammes, C., Pfannschmidt, G., Sen Gupta, P.R., Simon, S.B., Papike, J.J., and Beauchamp, R.H.: 1986, 'Shock Metamorphism and Petrography of the Shergotty Achondrite', Geochim. Cosmochim. Acta 50, 889-913.

Stöffler, D., Bischoff, A., Buchwald, U., and Rubin, A.E.: 1988, 'Shock Effects in Meteorites', in J.F. Kerridge and M.S. Matthews (eds.), Meteorites and the Early Solar System, Univ. Arizona Press, Tucson, pp. 165-205.

Swindle, T.D., Caffee, M.W., and Hohenberg, C.M.: 1986, 'Xenon and Other Noble Gases in Shergottites', Geochim. Cosmochim. Acta 50, 1001-1015.

Swindle, T.D., Nichols, R., and Olinger C.T.: 1989, 'Noble Gases in the Nakhlite Governador Valadares', Proc. 20th Lunar Planet. Sci. Conf., 1097-1098 (abstract).

Swindle, T.D., Grier, J.A., Burkland, M.K.: 1995, 'Noble Gases in Orthopyroxenite ALH84001: A Different Kind of Martian Meteorite with an Atmospheric Signature', Geochim. Cosmochim. Acta 59, 793-801.

Swindle, T.D., Li, B., and Kring, D.A.: 1996, 'Noble Gases in Martian Meteorite QUE94201', Proc. 27th Lunar Planet. Sci. Conf., 1297-1298 (abstract).

Swindle, T.D., Treiman, A.H., Lindstrom, D.J., Burkland, M.K., Cohen, B.A., Grier, J.A., Li, B., Olson, E.K.: 1999, 'Nobel Gases in Iddingsite from the Lafayette Meteorite: Evidence of Liquid Water on Mars in the Last few Hundred Million Years', Met. Planet. Sci. 35, 107-115.

Swindle T.D., Treiman, A.H., Lindstrom, D.J., Burkland, M.K., Cohen, B.A., Grier, J.A., Li B., and Olson E.K.: 2000, 'Noble Gases in Iddingsite from the Lafayette Meteorite', Met. Planet. Sci. 35, 107-116. 
Tanaka, K.L.: 1986, 'The Stratigraphy of Mars', Proc. 17th Lunar Planet. Sci. Conf., J. Geophys. Res. Suppl. 91, E139-158.

Tanaka, K.L., Scott, D.H., and Greeley, R.: 1992, 'Global stratigraphy', in H.H. Kieffer et al.(ed.) Mars, Univ. of Ariz. Press, Tucson, pp. 345-382.

Terribilini, D., Eugster, O., Burger, M., Jakob, A., and Krähenbühl, U.: 1998, 'Noble Gases and Chemical Composition of Shergotty Mineral Fractions, Chassigny, and Yamato-793605', Met. Planet. Sci. 33, 677-684.

Terribilini, D., Busemann, H., and Eugster O.: 2000, ${ }^{81} \mathrm{Kr}-\mathrm{Kr}$ Cosmic-ray Exposure Ages of Martian Meteorites Including the new Shergottite Los Angeles', Met. Planet. Sci. 35, A155.

Treiman, A.H.: 1985, 'Amphibole and Hercynite Spinel in Shergotty and Zagami: Magmatic Water, Depth of Crystallization, and Metasomatism', Meteoritics 20, 229-243.

Treiman, A.H.: 1987, 'Geology of the Nakhlite Meteorites: Cumulate Rocks from Flows and Shallow Intrusions', Proc. 18th Lunar Planet. Sci., 1022-1023.

Treiman, A.H.: 1995a, ' $\mathrm{S} \neq \mathrm{NC}$ : Multiple Source Areas for Martian Meteorites', J. Geophys. Res. 100, 5329-5340.

Treiman, A.H.: 1995b, 'A Petrographic History of Martian Meteorite ALH84001: Two Shocks and an Ancient Age', Meteoritics 30, 294-302.

Treiman, A.H.: 1998, 'The History of ALH84001 Revised: Multiple Shock Events', Meteorit. Planet. Sci. 33, 753-764.

Treiman, A.H., McKay, G.A., Bogard, D.D., Mittelfehldt, D.W., Wang, M.-S., Keller, L., Lipschutz, M.E., Lindstrom, M.M., and Garrison, D.: 1994, 'Comparison of the LEW88516 and ALH77005 Martian Meteorites: Similar but Distinct', Meteoritics 29, 581-592.

Tschermak, G.: 1872, 'Die Meteoriten von Shergotty und Gopalpur', Sitzungsberichte der mathematisch-naturwissenschaftlichen Classe der kaiserlichen Akademie der Wissenschaften $\mathbf{6 5}$ $122-146$.

Turner, G., Knott, S.F., Ash, R.D., Gilmour, J.D.: 1997, 'Ar-Ar Chronology of the Martian Meteorite ALH84001: Evidence for the Timing of the Early Bombardment of Mars', Geochim. Cosmochim. Acta 61, 3835-3850.

Vickery, A.: 1986, 'Effect of an Impact-generated Gas Cloud on the Acceleration of Solid Ejecta', $J$. Geophys. Res. 91, 14,139-14,160.

Warren, P.H.: 1994, 'Lunar and Martian Meteorite Delivery Services', Icarus 111, 338-363.

Warren, P.H.: 1998, 'Petrologic Evidence for Low-temperature, Possible Flood-evaporitic Origin of Carbonates in the ALH84001 Meteorite', J. Geophys. Res. 103, 16,759-16,773.

Wänke, H.: 1991, 'Chemistry, Accretion and Evolution on Mars', Space Sci. Rev. 56, 1-8.

Wänke, H., and Dreibus, G.: 1988, 'Chemical Composition and Accretion History of Terrestrial Planets', Phil. Trans. Roy. Soc. London A325, 545-557.

Wasson, J.T., and Wetherill, G.W.: 1979, 'Dynamical, Chemical, and Isotopic Evidence Regarding the Formation Locations of Asteroids and Meteorites', in T. Gehrels (ed.), Asteroids, Univ. Arizona Press, Tucson, pp. 926-974.

Wadhwa, M., and Crozaz, G.: 1994, 'Rare Earth Element Distributions in Chassigny: Clues to its Petrogenesis and Relation to the Nakhlites', Proc. 25th Lunar Planet. Sci., 1451-1452.

Wadhwa, M., and Lugmair, G.W.: 1996, 'The Formation Age of Carbonates in ALH84001', Met Planet. Sci. 31, A145.

Weiss, B.P., Kirschvink, J.L., Baudenbacher, F.J., Vali, H., Peters, N.T., Macdonald, F.A., and Wikswo, J.P.: 2000, ‘A Low Temperature Transfer of ALH84001 from Mars to Earth', Science 290, 791-795.

Wetherill, G.W.: 1988, 'Where do the Apollo Objects Come from?' Icarus 111, 1-18.

Wiens, R.C., and Pepin, R.O.: 1988, 'Laboratory Shock Emplacement of Noble Gases, Nitrogen, and Carbon Dioxide into Basalt, and Implications for Trapped Gases in Shergottite EET79001', Geochim. Cosmochim. Acta 52, 295-307. 
Wood, C.A., and Ashwal, L.D.: 1981, 'SNC Meteorites: Igneous Rocks from Mars', Proc. 12th Lunar Planet. Sci. Conf., 1359-1375.

Wooden, J.L., Nyquist, L.E., Bogard, D.D., Bansal, B., Wiesmann, H., Shih C.-Y., and McKay, G.A: 1979, 'Radiometric Ages for the Achondrites Chervony Kut, Governador Valadares, and Allan Hills 77005', Proc. 10th Lunar Planet. Sci., 1379-1381 (abstract).

Zipfel, J., Scherer, P., Spettel, B., Dreibus, G., and Schultz, L.: 2000, 'Petrology and Chemistry of the new Shergottite Dar al Gani 476', Met. Planet. Sci. 35, 95-106.

Address for correspondence: SN/Planetary Sciences, NASA Johnson Space Center, 2101 NASA Road 1, Houston, TX 77058-3696, USA;

(laurence.e.nyquist1@jsc.nasa.gov) 